\title{
THE EFECTS OF PSYCHOLOGICAL OWNERSHIP ON LOYAL CUSTOMERS' PERCEPTIONS: APPLYING BRAND TOURISM EFFECT AND CONSPICOUS CONSUMPTION TO LUXURY HOTEL MARKETING
}

\author{
A Dissertation \\ presented to
}

the Faculty of the Graduate School

at the University of Missouri

in partial fulfillment

of the Requirements for the Degree of

Doctor of Philosophy

by

SEUNG HWAN LEE

Dr. Dae-Young Kim, Dissertation Supervisor

December 2018 
The undersigned, appointed by the Dean of the Graduate School at the University of Missouri, have examined the dissertation entitled

THE EFECTS OF PSYCHOLOGICAL OWNERSHIP ON LOYAL CUSTOMERS' PERCEPTIONS: APPLYING BRAND TOURISM EFFECT AND CONSPICOUS CONSUMPTION TO LUXURY HOTEL MARKETING

presented by Seung Hwan Lee, a candidate for the degree of Doctor of Philosophy and hereby certify that, in their opinion, it is worthy of acceptance.

Dr. Dae-Young Kim, Hospitality Management

Dr. Eliza C. Tse, Hospitality Management

Dr. Pei Liu, Hospitality Management

Dr. Amanda Alexander, Hospitality Management

Dr. Nelson Cowan, Psychological Sciences 


\section{ACKNOWLEDGEMENTS}

Most of all, I give praise to the Lord Almighty to whom I owe my very existence for providing me this opportunity and granting me the capability to proceed successfully. I am grateful for His provision of challenges and grace for growth that have been bestowed upon me during this research work, and indeed, throughout my life: "I can do everything through Him who gives me strength." (Philippians 4: 13)

I would like to express the deepest appreciation and gratitude to the chair of my committee, Dr. Dae-Young Kim. As my academic advisor and mentor, he has taught me even more than I could ever give him credit for here. He has shown me, by his example, what a good scholar and person should be. I believe that without his priceless advice, countless moments of guidance and persistent encouragement, this dissertation would not have been possible.

I would also like to sincerely thank my dissertation committee members: Dr. Eliza Tse, Dr. Pei Liu, Dr. Amanda Alexander, and Dr. Nelson Cowan for their insightful comments, advice, and suggestions, but also for the challenging questions that prompted me to widen my research from various perspectives.

My gratitude is also extended to my colleagues, Dr. Kathleen Kim, Yejin Lee, Minjung Kim, Hyewon Lee, Ethan Cheng, Angie Lim, Beomjoo Kim, and Soojin Lee, all of whom provided me with continuous assistance and time to discuss research ideas.

The last note of my utmost appreciation I give to Dr. Yoo-Shik Yoon and Dr. Chulwon Kim at Kyung Hee University who have taught me the spirit of the adventure and provided me with a roadmap for my academic career. Thanks to their encouraging 
and insightful messages, I was able to start my academic career well. I will never forget their invaluable guidance.

Finally, this dissertation is dedicated to my parents and brother, Byeongsoo Lee, Sun-Young Park, and Kyunghwan Lee, my precious three children, Kyumin Lee, Kyuhyeong Nathan Lee, and Kyueun Charlotte Lee, and beloved my wife, Jiweon Kim, the people who have supported me with endless love. 


\section{TABLE OF CONTENTS}

\section{Contents}

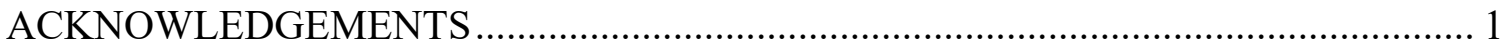

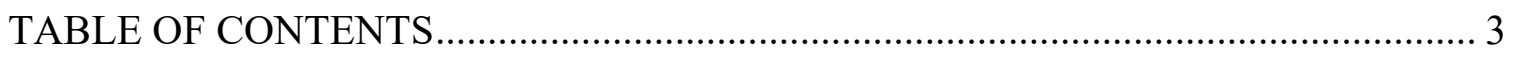

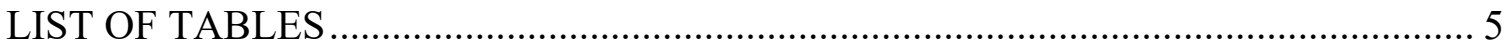

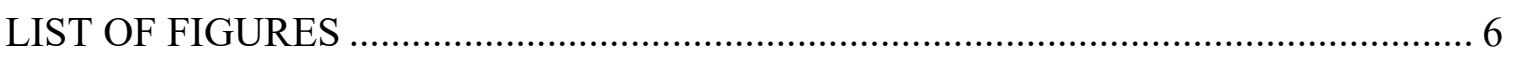

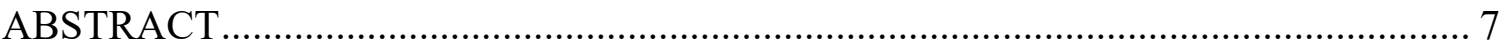

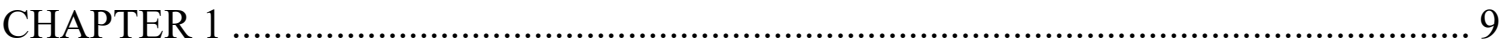

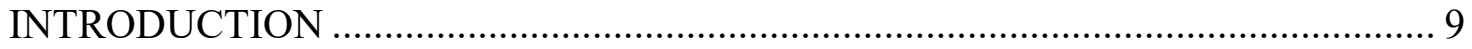

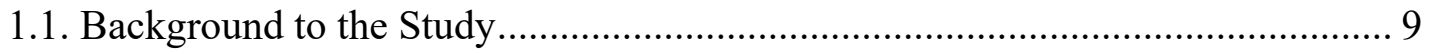

1.2. Statement of the Problem............................................................................. 14

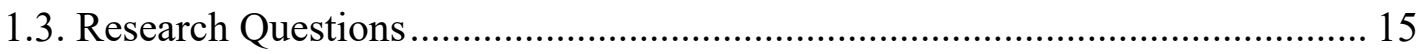

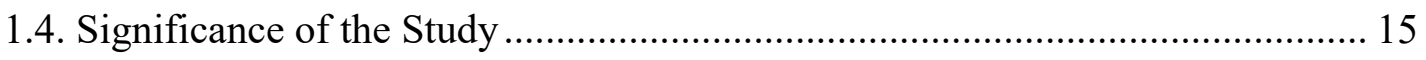

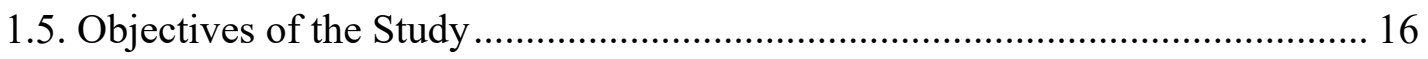

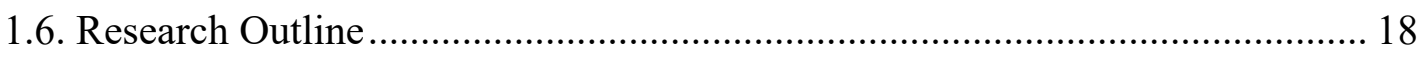

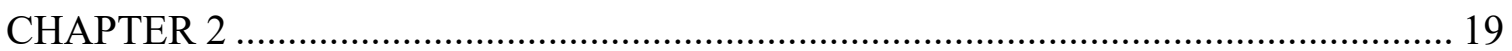

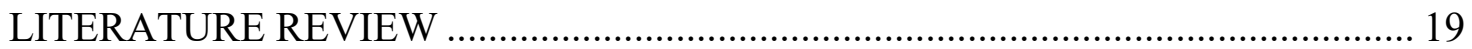

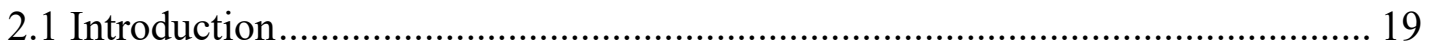

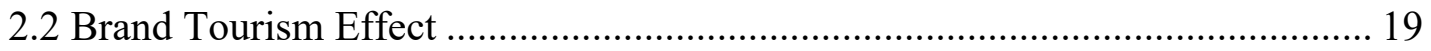

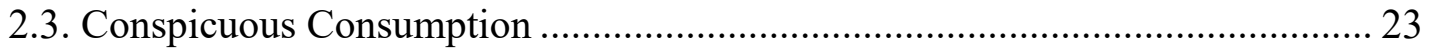

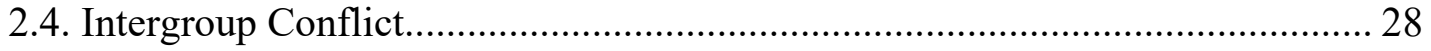

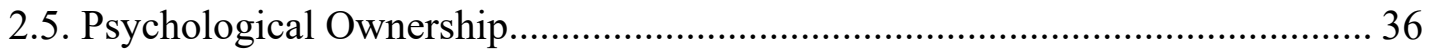

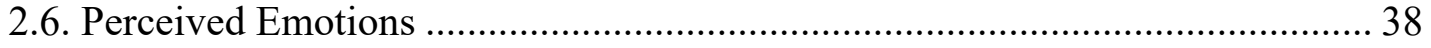

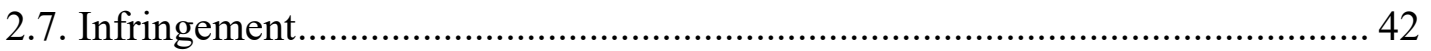

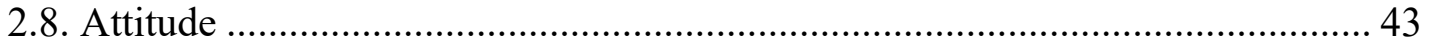

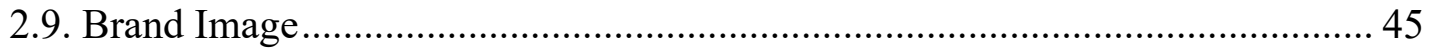

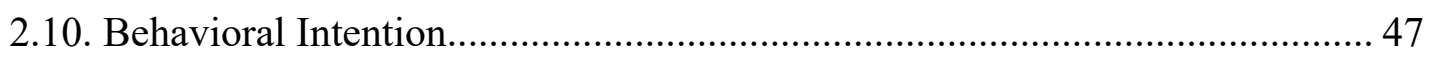

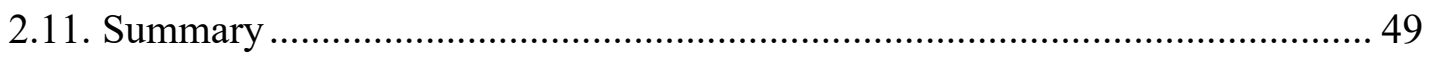

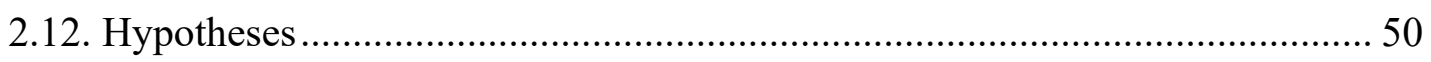

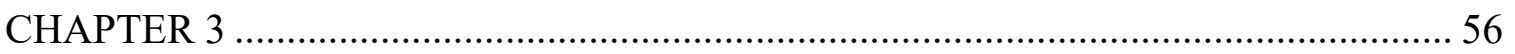

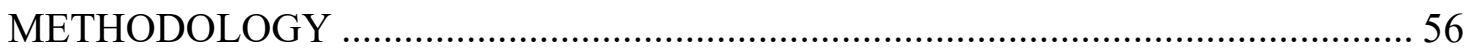

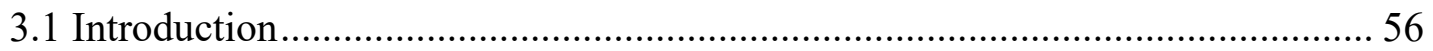

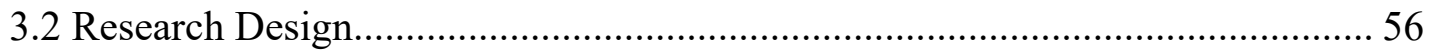




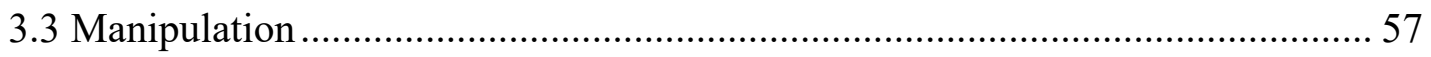

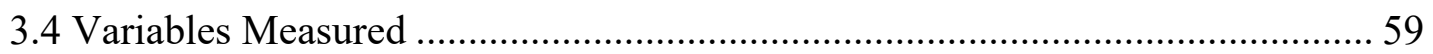

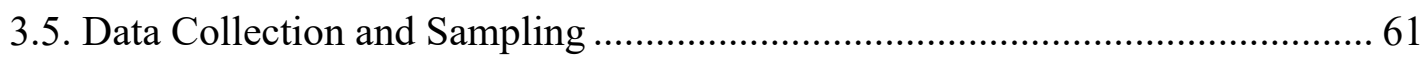

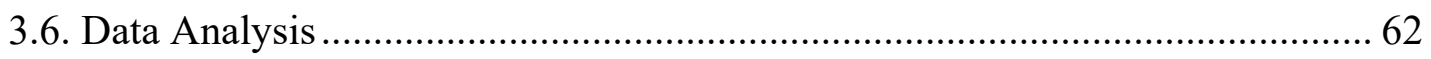

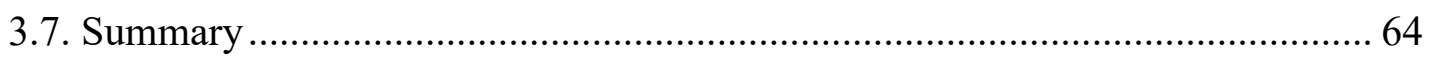

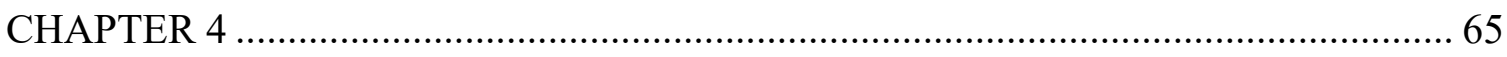

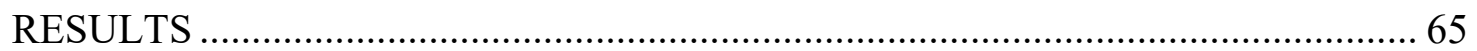

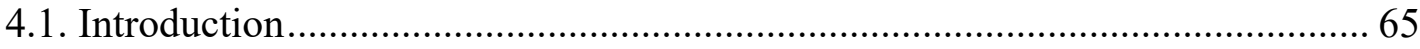

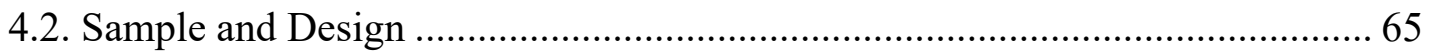

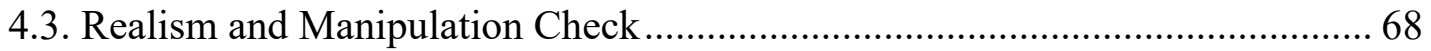

4.4. Loyal customers' Perceived Emotions and Their Effect on Psychological

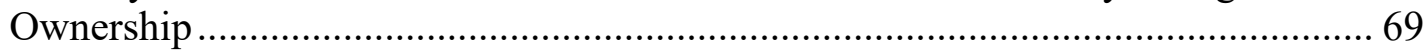

4.5. Loyal Customers' Perceptions and the Link to Psychological Ownership........ 72

4.6. The Relationship Among Loyal Customers' Perceptions of the Two Types of Non-Loyal Customers and Two Different Areas........................................................ 77

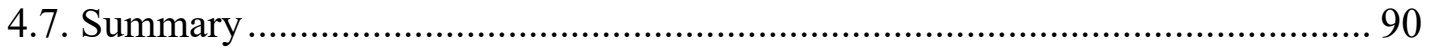

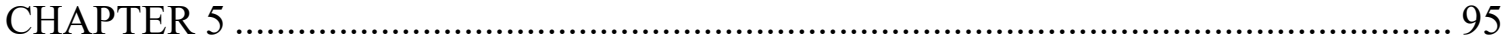

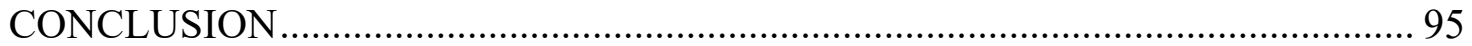

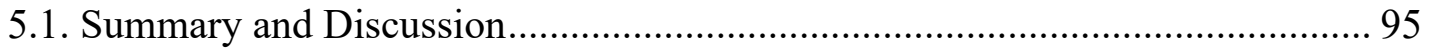

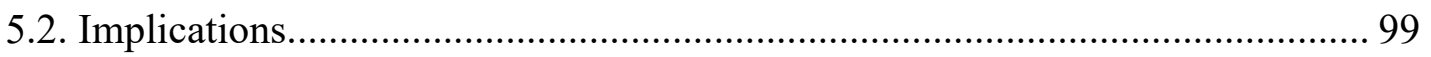

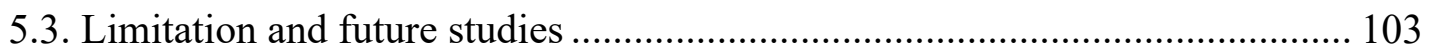

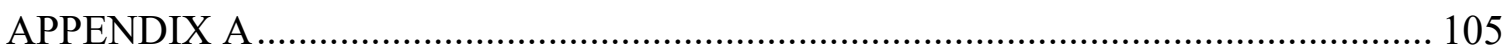

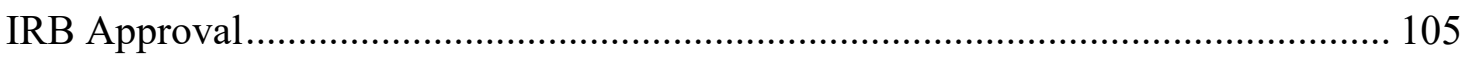

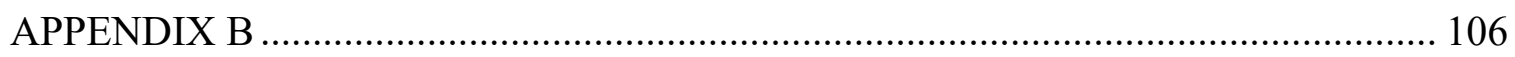

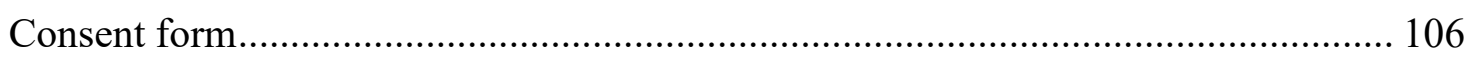

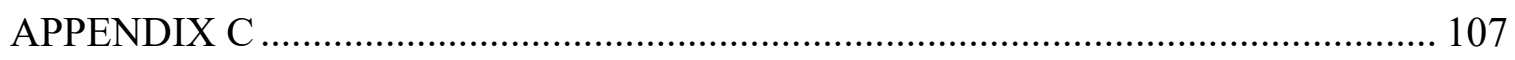

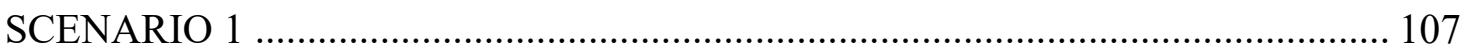

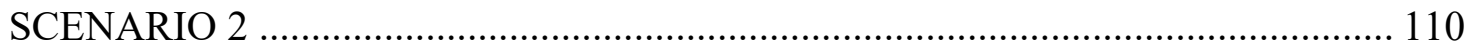

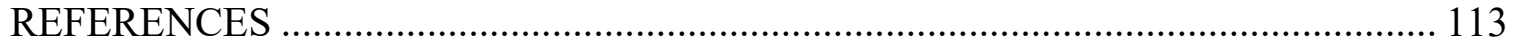

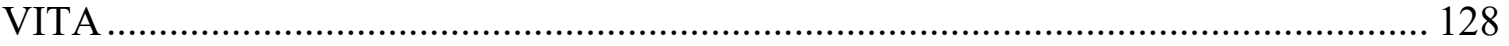




\section{LIST OF TABLES}

Table 1. Description of Brand Immigrants and Brand Tourists.................................. 21

Table 2. Two Types of Conspicuous Consumption Behaviors...................................... 24

Table 3. Theories Related to Intergroup Conflict .................................................... 30

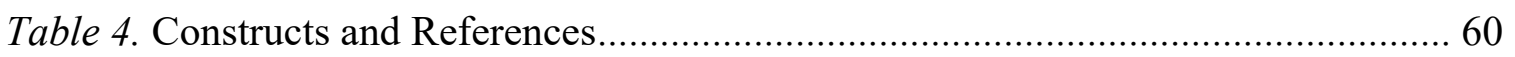

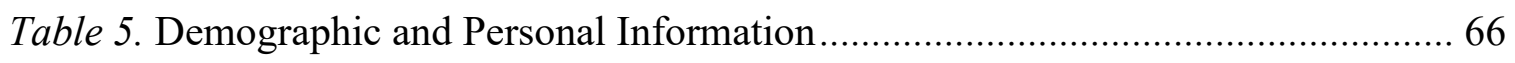

Table 6. Perceived Psychological Ownership of a Lounge and a Restaurant................... 69

Table 7. Results of Two-Way MANOVA for Loyal Customers' Emotions (Multivariate

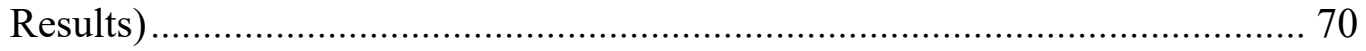

Table 8. Two-Way MANOVA Results for Dependent Variables .................................. 70

Table 9. Results of Two-Way MANOVA for Loyal Customers' Emotions (Multivariate

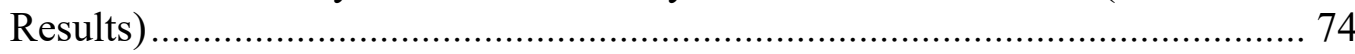

Table 10. Two-Way MANOVA Results for Dependent Variables................................. 74

Table 11. Overall Model Fit of PLS Structural Model ................................................... 79

Table 12. Result of Variance Inflation Factor (VIF) ............................................... 79

Table 13. Latent Variable Correlation (Brand Immigrant) ....................................... 80

Table 14. Latent Variable Correlation (Brand Tourist) ......................................... 80

Table 15. Loyal Customers' Different Perceptions of Brand Immigrants and Brand

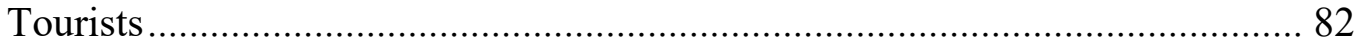

Table 16. Loyal customers' Different Perceptions Toward Brand Immigrants' Behavior in Different Areas ......................................................................................... 85

Table 17. Loyal Customers' Different Perceptions Toward Brand Tourists' Behavior in

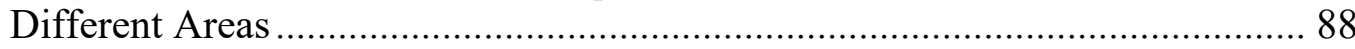

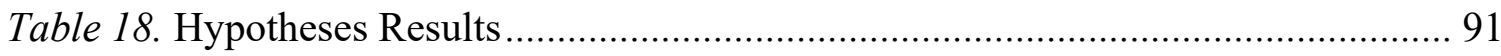




\section{LIST OF FIGURES}

Figure 1. Demand Curve of a Veblen Good................................................................ 26

Figure 2. Framework for the Examining Differences of Loyal Customers' Perceptions of

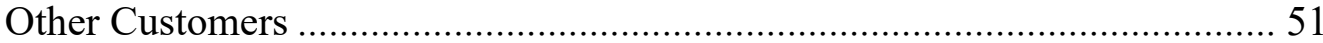

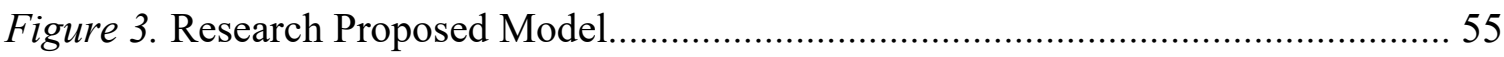

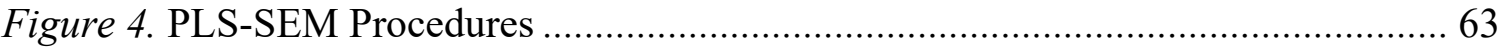

Figure 5. Structural Model Assessment Procedure ……………………...................... 64

Figure 6. Interactions of the Type of Non-Loyal Customers with Psychological

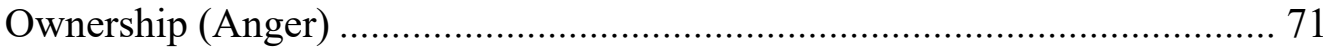

Figure 7. Interactions of the Type of Non-Loyal Customers with Psychological Ownership (Disappointment) ..................................................................... 72

Figure 8. Interactions of the Type of Non-Loyal Customers with Psychological

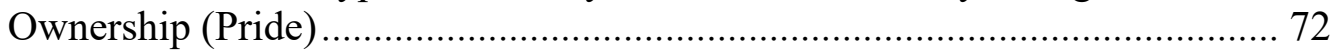

Figure 9. Interactions of the Type of Non-Loyal Customers with Psychological

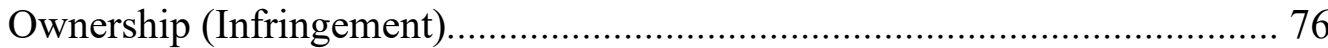

Figure 10. Interactions of the Type of Non-Loyal Customers with Psychological Ownership (Attitude)

Figure 11. Interactions of the Type of Non-Loyal Customers with Psychological Ownership (Brand Image)

Figure 12. Interactions of the Type of Non-Loyal Customers with Psychological Ownership (Switching Intention).

Figure 13. Structural Model of Loyal Customers' Perceptions on Brand Immigrants .... 83

Figure 14. Structural Model of Loyal Customers' Perceptions on Brand Tourists.......... 83

Figure 15. Structural Model of Loyal Customers' Perceptions on Brand Immigrants in the Lounge.

Figure 16. Structural Model of Loyal Customers' Perceptions on Brand Immigrant in the Restaurant. 86

Figure 17. Structural Model of Loyal Customers' Perception on Brand Tourists in the Lounge

Figure 18. Structural Model of Loyal Customers' Perception on Brand Tourists in the Restaurant. 


\title{
THE EFECTS OF PSYCHOLOGICAL OWNERSHIP ON LOYAL CUSTOMERS' PERCEPTIONS: APPLYING BRAND TOURISM EFFECT AND CONSPICOUS CONSUMPTION TO LUXURY HOTEL MARKETING
}

\author{
Seung Hwan Lee \\ Dr. Dae-Young Kim, dissertation supervisor
}

\begin{abstract}
This study aims to examine the conflict between loyal customers and non-loyal customers in the luxury hotel environment. This research mainly applied the concept of brand tourism effect and employed a 2 (two types of non-loyal customers: brand immigrants and brand tourists) $\times 2$ (areas divided by psychological ownership: lounge vs. restaurant) mixed experimental design on the dependent variables (i.e., emotions, infringement, attitude, brand image, and switching intention) and 934 participants were recruited from nationwide online panels. To investigate loyal customers' different brand perceptions from non-loyal customers, MANOVA was performed and to examine the relationship among infringement, attitude, brand image, and switching intention, PLSSEM was conducted.
\end{abstract}

The result revealed that loyal customers negatively perceive brand immigrants and positively perceive brand tourists. Loyal customers perceive higher levels of infringement and switching intention when they view brand immigrants, while loyal customers perceive positive attitude and brand image when they view brand tourists. Psychological ownership, which divided the background into lounge and restaurant, is also found to play a moderating role in loyal customers' perceptions of brand tourists and brand immigrants on infringement, attitude, and switching intention. In addition, for 
brand immigrants, infringement is positively related to switching intention, and attitude and brand image are negatively linked with switching intention, while for brand tourists, infringement is the only variable that has a positive influence on switching intention. In sum, the current study demonstrated that loyal customers perceive brand differently depending on the types of customers (i.e., brand tourists and brand immigrants) and two types of backgrounds (i.e., lounge and restaurant). Finally, the theoretical and empirical contributions of the present study are discussed. 


\section{CHAPTER 1}

\section{INTRODUCTION}

\subsection{Background to the Study}

The desire for luxury items is attributable to the luxury brands' intrinsic traits and beneficial values (Roux, Tafani, \& Vigneron, 2017) that can be attained by possessing and using them (Cristini, Kauppinen-Räisänen, Barthod-Prothade, \& Woodside, 2017). Generally, consumers purchase these goods because they perceive the remarkable quality of certain brands (Choo, Moon, Kim, \& Yoon, 2012) and believe them to be more attractive than non-luxury goods. People are more likely to wish to own luxury brand items due to intrinsic features, such as high quality, excellent craftsmanship, creativity, uniqueness, and innovation. Since the owners often feel that these products are exclusive, rare, and unique, luxury products come at a premium price (Kapferer \& Laurent, 2016). These features also imply that not all consumers can access or possess luxury products (e.g., Roper, Caruana, Medway, \& Murphy, 2013) and essentially these items indicate the prestigious position of their owners or users. Luxury goods are things that most people would like to own and use, but only a privileged few can obtain. Luxuries are a symbol of one's status, and brand logos provide benefits in everyday social interactions, thereby meeting new luxury consumers' desires (Kastanakis \& Balabanis, 2012).

The luxury hotel market within the hospitality industry has grown considerably in recent years, primarily due to the rise in the number of wealthy international business travelers (Höger, 2018). Customers’ preferences for opulent surroundings and amenities continue to grow, and it is up to hotel managers to see that these customers are satisfied and that they look forward to returning. Advances in the hospitality and travel industry, 
an increase in the desire for leisure travel, and an improved standard of living drive the luxury hotel market (Ting, 2016). According to a study by Allied Market Research (Upadhayay, 2017), the surge in leisure travel and the number of wealthy business travelers has greatly expanded the luxury hotel industry. Specifically, this study revealed; (a) the luxury hotel market that was valued at $\$ 15.5$ million in 2015 is likely to reach $\$ 20.4$ million by 2022 and (b) business hotels accounted for approximately $42 \%$ of the total market revenue in 2015 .

According to another recent market research report conducted by Smith Travel Research (STR) (2017), the U. S. luxury segment had the highest occupancy rate (76.5\%) in the second quarter of 2017. The following two key factors have led to the strong performance of luxury hotels: (1) rising individual income throughout the world and (2) the advent of new distribution channels for offering discounts such as flash sales or lastminute deal websites. In addition, many scholars in the hospitality industry have paid close attention to the significant popularity of luxury hotels and the general phenomenon of luxury consumption. These researchers often emphasize the consumers' emotional attachment to a particular brand due to the fact that the luxury market, such as high-end hotels, is closely related to hedonic motivation (Hyun \& Kim, 2014), status seeking (Yang \& Mattila, 2013), and customer loyalty (Yang \& Lau, 2015).

For these reasons, many luxury hotel executives have attempted to increase business by attracting more customers and focusing their efforts on loyalty programs, similar to other hotel companies. Customers are likely to remain loyal to a particular hotel brand in order to obtain the economic benefits the firm provides (Mattila, 2006). In addition to economic benefits, loyalty programs also offer social rewards, such as preferential treatment and personalized service, to retain their customers. For example, 
hotel staff are trained to call customers by name. (Berry, 1994; Gwinner, Gremler, \& Bitner, 1998; Peterson, 1995). Therefore, guests tend to obtain hedonic value, such as emotional benefits, at luxury hotels (Walls, Okumus, Wang, \& Kwun, 2011). Interestingly, these rewards programs operated for loyal customers, have been found to build more robust relationships with loyal customers than economic benefits or incentives, because these benefits enhance fundamental reasons for sustaining and strengthening emotional attachment and commitment (Deci \& Ryan, 1985). In other words, social rewards reaped from hotel loyalty programs reinforce the members' perceptions of affective commitment through emotional attachment to the hotel (Lee, Tsang, \& Pan, 2015). However, because hotel executives also attempt to use these perks to entice general customers, those benefits actually wind up weakening the differentiation between loyal and non-loyal customers (Martin, 2015).

This occurrence has also been seen in other aspects of the hospitality industry. For example, overcrowding in airport lounge areas is becoming a crucial issue for the airline industry (Mcginnis, 2017), which causes many frequent flyer members to consider switching airlines or exploring more convenient options. Customers are more likely to stick with a particular company, even if they are members of more than two loyalty programs, because of the promise of becoming eligible for specific benefits such as using club lounges (Söderlund \& Colliander, 2015). In the past, most airline clubs could be counted on to be a cozy, quiet, and comfortable refuge from crowded airport concourses. However, these benefits have changed recently as airlines have begun to offer one-time fee-based access, and credit card companies affiliated with airline firms began to offer membership or day passes to cardholders (Martin, 2015). Nowadays, overcrowding is an issue not only in hotel lounges but also at airport lounges. On some review sites, such as 
TripAdvisor or hotels' own websites (e.g., Marriott rewards), many guests have reported disappointment with these conditions.

The aforementioned problems can largely be explained by Bellenzza and Keinan's brand tourism effect (2014), a conflict which occurs when non-core consumers purchase and utilize luxury items that were previously limited to a select few loyal consumers. These loyal consumers want companies to maintain their distinct and unique brand reputation (Amaldoss \& Jain, 2005; Han, Nunes, \& Drèze, 2010). However, brand value attenuates when firms allow too many people who are perceived as undesirable to have access to products and services through alternative means (Berger \& Heath, 2008; White \& Dahl, 2007). Therefore, the brand tourism effect (Bellenzza \& Keinan, 2014) comes into play. Basically, there are two types of brand consumers: core users and noncore users. The former are frequent consumers of the brand's core offering, while the latter are consumers who obtain access to the brand by consuming one of its non-core offerings (Bellenzza \& Keinan, 2014).

Furthermore, the brand tourism effect focuses on the latter group, non-core users, who are referred to as either "brand tourists" or "brand immigrants" depending on how they are viewed by core users (Bellenzza \& Keinan, 2014). Basically, regarding these two terms, one is perceived positively, while the other, which arises from the differences between tourists and immigrants, can be viewed negatively. To be specific, the brand tourist label implies a temporary state and an intention to leave the destination soon, whereas the term brand immigrant implies a longer or permanent stay. In fact, these terms were developed and conceptualized by researchers from a wide range of disciplines, including psychology, marketing, and sociology. The former is defined as "those who claim to be part of the in-group of core users of the brand" and the later as "those who 
buy the non-core branded products but do not claim any in-group membership" (Bellenzza \& Keinan, 2014).

The brand tourism effect is evident in the hospitality industry, as illustrated in the exclusive prestige lounges in luxury hotels and airports. However, sometimes, ineligible guests gain free access to these perks through credit card benefits. In this situation, exclusive club members are the core users and other guests who enter the lounge via other means are considered non-core users. In this situation, core users perceive themselves as distinct from non-core users. As a result, core users feel either anger and disappointment or pride depending on whether the non-core users are brand tourists or brand immigrants (Bellenzza \& Keinan, 2014).

To delve deeper into the relationship between core users and non-core users, this study integrated theories on territorial behavior or territoriality (Brown, 2009; Brown, Lawrence, \& Robinson, 2005) related to psychological ownership (Brown, Pierce, \& Crossley 2014; Peck \& Shu, 2009; Pierce, Kostova, \& Dirks, 2003) and applied it to scenarios in which consumers perceive infringement and respond territorially, depending on their personal level of psychological ownership. For example, when core users access a lounge provided exclusively for loyal consumers, they might experience proprietary feelings about it and develop a strong relationship with that brand of hotel (Peck \& Shu, 2009). The psychological (emotional or cognitive) bond with an object of ownership represents the essence of what Pierce, Kostova, and Dirks (2001) and Pierce et al. (2003) refers to as psychological ownership.

One prior study (Brown et al., 2005) regarding territoriality suggests that since people are sensitive to the proprietary lines that define the boundaries of their various 
psychologically owned targets, the potential for perceived infringement and subsequent territorial responses may be particularly high in the luxury hospitality market. Core users might be disturbed by the presence of non-core users because they feel that they own the lounge, at least psychologically (Kirk, Peck, \& Swain, 2018). Thus, this study examined the psychological and emotional factors involved in luxury hospitality environment.

\subsection{Statement of the Problem}

Many organizations in the hospitality industry focus and rely on loyalty programs that not only help them retain their core users, but also attract additional non-core users (Lee et al., 2015). Specifically, because only minor differences exist among hotels' product attributes, they are more likely to differentiate their products and services by offering attractive benefits, such as monetary rewards (Kotler, Bowen, \& Makens, 2013; Lee \& Kim, 2018). For example, most hotel companies offer private areas where only loyal customers have access so that they perceive that they differ from non-loyal customers (Chang \& Tarn, 2008). However, some problems have occurred recently in the hotel industry. Many credit card companies affiliated with hotel companies now offer their card holders the benefits of free access to exclusive amenities in a hotel.

Accordingly, many hotels allow those credit card holders who are not loyal customers to enter the lounge. This decision could cause loyal customers to complain because the exclusive area is sometimes subject to overcrowding (Androitis, 2018). In these circumstances, an intergroup conflict might occur between loyal and non-loyal customers, because loyal customers perceive that non-loyal customers are infringing on their amenities, and the differentiation between loyal and general customers is attenuated (Brown \& Robinson, 2011). For these reasons, loyal customers may have negative attitudes about non-loyal customers and they may develop a negative image of the brand. 
Finally, some loyal customers may switch brand allegiance and may cease to patronize the hotel (Kirk et al., 2018).

\subsection{Research Questions}

The following research questions guided this study: (1) How do loyal customers perceive non-loyal customers in luxury hotels? (2) In the luxury hotel market, how do non-loyal customers' behaviors impact loyal customers' brand perception? (3) How do luxury hotels maintain positive long-term relationships with all their guests?

According to the brand tourism effect, core users might perceive non-core users as either brand tourists or brand immigrants (Bellenzza \& Keinan, 2014). This current study attempts to examine the phenomenon whereby brand tourists cause core users to feel pride, while brand immigrants inspire negative emotions in core users, such as disappointment or anger. Furthermore, core users' emotions that are triggered by noncore users might positively or negatively affect their feeling of infringement, their attitudes, their view of the brand image, and their loyalty. This study might help those in the hotel industry, specifically in luxury hotels, to find useful and effective strategies for retaining their loyal customers as well as for attracting new ones while decreasing the negativity that exists between loyal customers and non-loyal customers.

\subsection{Significance of the Study}

This study is significant because it examines a current issue in diverse sectors of the hospitality and tourism industry such as hotel lounges or airport lounges. The concept of brand tourism effect that is applied in this study is comparably novel in the business area and its first use was in the hospitality industry. This study is a detailed analysis of 
the brand tourism effect in luxury hotel context. In addition, in the context of brand marketing, while prior studies have focused on how companies are able to gain loyal customers, such as strategies to make customers loyal or customer retention strategies, a limited amount of research has examined the conflict between different types of customers (i.e., loyal customers and non-loyal customers). For example, Ashley and Noble (2014) examined the conflict between customers arising from infringement by other customers in the restaurant context. The current study extends the existing literature by investigating the influence of the level of psychological ownership on loyal customers' brand perception.

Based in the concept of brand loyalty, this research will contribute to brand marketing literature by offering an insight into how hotel firms manage and operate loyalty programs to retain core users and to attract brand tourists. By focusing on the traits of non-loyal customers, the study might help hotel executives to improve the hotel's image as well as to mitigate the effect of brand immigrants. This study also aims to help hotel marketers to find some insights on how they can attract new customers and meet their expectations without diluting loyal customers' perception of differentiation from other customers.

\subsection{Objectives of the Study}

The followings are the three main purposes of this study: (1) to examine the various perceptions that arise when core users view brand tourists and brand immigrants; (2) to investigate the moderating role that psychological ownership plays in core users' perceptions of the two types of non-core users; (3) to examine the different relationships 
among core users' perceptions, such as infringement, attitude, brand image, and switching intention in relation to non-core users.

To be specific, this study has the following objectives:

1. To identify differences in loyal customers' different perceptions (emotion, infringement, attitude, brand image, and switching intention) of non-loyal customers depending on how the non-loyal customers are perceived by loyal customers in the luxury hotel market.

2. To explore the moderating role of psychological ownership in the lounge and restaurant and their relationships to infringement, attitude, brand image, and switching intention in the luxury hotel market.

3. To investigate the relationships among loyal customers' different perceptions of brand immigrants and brand tourists in lounges and restaurants where a different level of psychological ownership have been identified in the luxury hotel market.

4. To provide recommendations for insightful marketing strategies to build longterm relationships with both loyal customers and non-loyal customers in the luxury hotel market.

To explain these relationships more effectively, this study applied four significantly related concepts: brand tourism effect, conspicuous consumption, intergroup conflict, and psychological ownership. This study examined how loyal customers in luxury hotels have different perceptions of two different types of non-loyal customers and how psychological ownership affects these relationships. The goals of this study are to present effective marketing and operating strategies to build long-term relationships with 
all consumers (i.e., loyal customers and non-loyal customers) in the luxury hotel market. The findings could help luxury hotel executives to perform appropriate marketing strategies aimed at both new customers and loyal customers.

\subsection{Research Outline}

The next chapter presents hypotheses and a research model, based on a review of the literature related to brand tourism effect, psychological ownership, infringement, attitude, brand image, and switching intention. Chapter 3 will present the methodology of the empirical study of consumers in the luxury hotel market to estimate the proposed research model and Chapter 4 will show the results of this study by performing diverse research methodologies to test the hypotheses. Finally, in Chapter 5, the study will be concluded with theoretical and managerial implications providing insightful suggestions, study limitations, and directions for future research. 


\section{CHAPTER 2}

\section{LITERATURE REVIEW}

\subsection{Introduction}

This chapter is divided into the following sections: the first section is a literature review of the brand tourism effect as seen in the luxury hotel market, followed by a discussion of conspicuous consumption, intergroup conflict, and psychological ownership, which are the other important concepts forming the background of this study. A discussion follows on core users' perceptions of infringement, attitude, brand image and switching intention by two different types of non-core users. The second section introduces the conceptual framework and hypotheses.

\subsection{Brand Tourism Effect}

Individuals mainly utilize products or services either to satisfy utilitarian or hedonic values. Utilitarian values include functional features such as economic value, convenience, or time savings (Jarvenpaa \& Todd, 1997; Teo, 2001; Zeithaml, 1988). However, consumers also purchase products for their hedonic or symbolic value to enable them to express their identities though the items they own (Loureiro \& de Araújo, 2014). In this vein, the concept of the brand tourism effect explains a product's symbolic or hedonic value. For example, when consumers purchase luxury brand items such as expensive watches or highly sought-after designer bags, they might consider themselves to be members of an exclusive group who are able to obtain a greater brand value overall (Bellezza \& Keinan, 2014). 
According to many recent branding studies, consumers wish to develop a relationship with a specific brand to satisfy their need to establishing an identity (Escalas \& Bettman, 2003; Fournier, 1998). Then, they are more likely to share information about a brand with other consumers (Bearden \& Etzel, 1982; Childers \& Rao, 1992; Muniz \& O'Guinn, 2001). These consumers believe that they have participated in the creation and improvement of the value of the brand and are eager to show their feelings of pride in becoming members of a brand community (Decrop \& Derbaix, 2010). This phenomenon occurs more frequently in the luxury market because members perceive that such brands are unique and exclusive (Stokburger-Sauer \& Teichmann, 2013). For this reason, marketing executives may offer opportunities to non-members who also wish to experience the brand and join the in-group. However, when people perceive that they have formed a connection with undesirable members, some will lose interest in the ingroup because they believe that the brand value has been reduced (Bian \& Forsythe, 2012).

Bellezza and Keinan (2014) describe this phenomenon as the "brand tourism effect" by utilizing an analogy between country and brand and the concepts of "brand tourist" and "brand immigrant." By applying political and sociological perspectives (Kosterman \& Feshbach, 1989; McLaren \& Johnson, 2007), they describe the various situations of immigrants and tourists at a destination and attempt to apply these terms to diverse types of brand customers. According to these authors, residents may perceive immigrants as a threat and treat them badly. To explain this terminology, they adopt the concept of group conflict from political science (Kosterman \& Feshbach, 1989) in which residents are likely to perceive minority groups as a potential threat to their in-group 
community. From their perspective, immigrant groups take useful resources and receive benefits that residents believe belong to them alone (McLaren \& Johnson, 2007).

Table 1

Description of Brand Immigrants and Brand Tourists

\begin{tabular}{ll}
\hline Type of Consumers & Description \\
\hline Brand immigrants & Brand immigrants refer to consumers who claim group \\
membership and they pose a threat to the image and \\
distinctiveness of selective brands. \\
Brand tourists & $\begin{array}{l}\text { Brand tourists are defined as consumers who do not claim } \\
\text { prestige. }\end{array}$
\end{tabular}

Note. Quoted from Bellezza and Keinan (2014).

In contrast to immigrants, residents are more likely to welcome tourists because they spend their money at the destination and leave, and the extent of their spending reflects the destination's economic status (Sharpley, 2014). According to their findings, residents are more likely to have positive attitudes toward tourists than immigrants. Also, residents are able to recognize the economic benefits tourism provides, and that tourism increases residents' pride in their community and makes them feel good about themselves (Tovar \& Lockwood, 2008). Residents feel proud when tourists visit their city (Alhammad, 2012) and are honored to live in a place with many tourist attractions (Huh \& Vogt, 2007).

Bellezza and Keinan (2014) imply that a classification of non-core users in the luxury market occurs when consumers claim in-group status by getting involved in the 
brand community. They present examples such as full-time students at Harvard University, Prada handbag owners, or Lomography camera owners, who are considered the core users of these brands, while non-core users are consumers who obtained or purchased these items (e.g., students taking online courses at Harvard University, Prada keychain owners, smartphone Lomography application users) as non-core consumers. Non-core users can be viewed either as "brand tourists" or "brand immigrants." The first group are people who utilize the non-core products of certain brands, but do not claim membership status (e.g., students taking online courses, but who do not name Harvard University in their resumes, Prada keychain owners who do not claim to be members of the brand community, the smartphone app users who do not view themselves as "Lomographers"). In contrast, they define brand immigrants as those who purchase noncore items of a brand and then claim to be members of that brand community (e.g., students taking online courses who name Harvard University in their resumes, Prada keychain owners who claim to be members of the brand community, smartphone app users who view themselves as "Lomographers").

Bellezza and Keinan (2014) approach their research to brand extension in the context of business brand marketing. Their study indicates that when one prestigious brand's marketing executives attempt to reach a wider customer base, the brand image that core users perceive can be attenuated, in that core users (brand residents) may perceive themselves as threatened by non-users (brand immigrants). Using the brand tourism effect, this researcher examined the ways in which companies maintain a relationship with core users by avoiding brand dilution by brand immigrants while enhancing the experiences of brand tourists. In this study, the core user is referred to as a loyal customer and the non-core user is referred to as a non-loyal customer. 
This study applies the concept of brand tourism effect to the hospitality industry and it examines the luxury hotel market that offers an exclusive amenity to loyal customers. In addition, based on the definition of the concept, three types of guests were selected and presented: loyal customers, who are officially eligible to use the lounge as a loyal customer; brand immigrants, who have access to the lounge due to inexpensive promotional packages deals provided by hotels or an affiliated credit card benefits, and who perceive themselves as members of the core brand users' in-group; and brand tourists, who have access to the lounge due to inexpensive packages, but do not claim to be part of the core brand users' in-group.

\subsection{Conspicuous Consumption}

In terms of conspicuous consumption, Veblen (1899) was one of first to mention that people mostly consume goods or services to communicate and show their economic status to others. In Veblen's work of 'The theory of the leisure class: an economic study in the evolution of institutions' in 1899 , he introduced the term 'conspicuous consumption' and explained that wealthy people attempted to retain their given social status by consuming highly conspicuous products to display their wealth to other people. That is to say that people in a higher social class are likely to display their economic superiority by spending time in the practice of leisure activities and by spending significant amounts of money on luxury goods and services (Trigg, 2001). Based on Veblen's work, many scholars focused on revealing what makes people desire luxury goods (Bagwell \& Bernheim 1996; Kastanakis \& Balabanis, 2014; O’Cass \& McEwen, 2004; Rucker, Galinsky, \& Dubois 2012). 
Table 2

Two Types of Conspicuous Consumption Behaviors

\begin{tabular}{|c|c|c|c|}
\hline Effects & Definition & Purposes & Sources \\
\hline $\begin{array}{l}\text { Veblen } \\
\text { effect }\end{array}$ & $\begin{array}{l}\text { "The extent to which } \\
\text { the demand for a } \\
\text { consumer good is } \\
\text { increased because it } \\
\text { bears a higher rather } \\
\text { than a lower price" }\end{array}$ & $\begin{array}{l}\text { To identify consumers' } \\
\text { economic status through } \\
\text { purchasing higher priced } \\
\text { goods }\end{array}$ & $\begin{array}{l}\text { Products or } \\
\text { services requiring } \\
\text { higher price }\end{array}$ \\
\hline $\begin{array}{l}\text { Bandwagon } \\
\text { effect }\end{array}$ & $\begin{array}{l}\text { "The extent to which } \\
\text { the demand for a } \\
\text { commodity is } \\
\text { increased due to the } \\
\text { fact that others are } \\
\text { also consuming the } \\
\text { same commodity" }\end{array}$ & $\begin{array}{l}\text { (1) Association with major } \\
\text { luxury consumers, which } \\
\text { allows them to dissociate } \\
\text { from less affluent } \\
\text { consumers } \\
\text { (2) Acquisition of status } \\
\text { (in-group member status) }\end{array}$ & $\begin{array}{l}\text { Popularity (e.g., } \\
\text { majority groups, } \\
\text { celebrities, } \\
\text { fashion, } \\
\text { conformity) } \\
\text { Status by } \\
\text { assimilation }\end{array}$ \\
\hline Snob effect & $\begin{array}{l}\text { "The extent to which } \\
\text { the demand for a } \\
\text { consumer good is } \\
\text { decreased owing to } \\
\text { the fact that others } \\
\text { are also consuming }\end{array}$ & $\begin{array}{l}\text { 1) Dissociation from the } \\
\text { other luxury consumers to } \\
\text { establish uniqueness } \\
\text { 2) Acquisition of status } \\
\text { (Dissociative status by } \\
\text { being different from the }\end{array}$ & $\begin{array}{l}\text { Unique resources } \\
\text { (e.g., scarcity, } \\
\text { novelty, } \\
\text { differentness) } \\
\text { Status resulting } \\
\text { from contrast }\end{array}$ \\
\hline
\end{tabular}




\begin{tabular}{ll}
\hline the same & majority of luxury \\
commodity" & consumers $)$
\end{tabular}

Note. Quoted from Leibenstein (1950) and Kastanakis \& Balabanis (2014).

Many scholars have studied the interpersonal social behaviors that inspire consumers to differentiate themselves from others (Truong, McColl, \& Kitchen, 2009; O'Cass \& McEwen, 2004). In Veblen's 1899 work 1899, he stated that wealthy people in the 'leisure class' wanted to become involved in 'conspicuous consumption' in order to ostentatiously communicate wealth, and they thought they could obtain higher social status when they purchased expensive products or services. Based on Veblen's treatise on the 'leisure class', Leibenstein (1950) explored the 'Veblen effect' in greater depth and found that a higher priced item creates greater demand than one of lower price. In addition, he examined two more forms of interpersonal effects regarding conspicuous consumption, the snob effect and bandwagon effect (see Table 2). First, the snob effect is a phenomenon which occurs when demand for a consumer good decreases as the number of consumers rises because people want to be different and to stand out from the crowd by buying exclusive and expensive items and thereby disassociating themselves from others. Second, there is the bandwagon effect, in which demand for a commodity increases as consumers tend to follow others in their reference groups who have already purchased the commodity. 


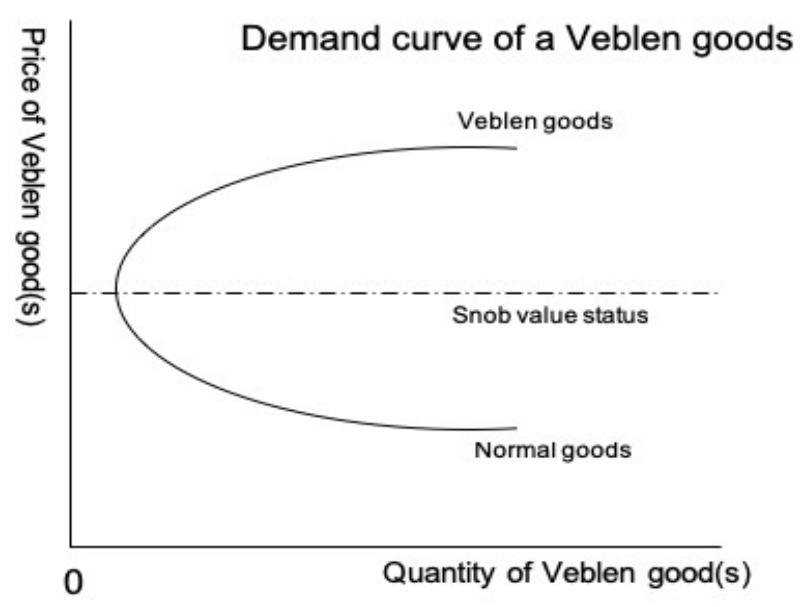

Figure 1. Demand curve of a Veblen good

With regard to these opposing concepts, Kastanakis and Balabanis (2014) argue that a consumer's personality might determine his or her fondness for relational versus contrast-creating brands. Relational attributes appeal to those with inter-dependent personalities and high susceptibility to normative influences. They would be influenced by the bandwagon effect (Tynan, McKechnie, \& Chhuon, 2010). On the other hand, those with individualistic traits are associated with independent personality types who have a need to express their uniqueness. They would be motivated by the snob effect of luxury consumption because they wish to differentiate themselves from others. As a limited number of consumers are able to obtain luxury products, it is crucial to understand the subtle differences among consumer motivations. Such insights can inform socioeconomic analyses of perceptions of status. By obtaining highly symbolic products such as luxurious products or scarce items (Wiedmann, Hennigs, \& Siebels, 2009), consumers can achieve a sense of belonging to an upper class or a feeling of dissociation from other consumers. 
Furthermore, some people enjoy conspicuous consumption because it enriches their self-esteem (O’Cass \& McEwen, 2004; Vigneron \& Johnson, 1999). For example, people with high social status who are highly conscious of other people tend to consume products with conspicuous signals to show their consumption to others. However, people with high needs for privacy are less likely to indicate their consumption behavior to other individuals, because their motivation is their personal satisfaction or enjoyment (Berger \& Ward 2010), rather than the opinions of others. Conversely, according to Rucker and Galinsky (2008), people of low social status are willing to spend their money on certain products that will allow them to appear wealthy. Researchers (Goldsmith, Flynn, \& Eastman, 1996; Piron, 2000; Wong \& Zhou, 2005) have proposed two different types of consumption behavior involving the purchase of conspicuous and of inconspicuous products. The former might include clothing, automobiles, watches, and mobile phones, while inconspicuous consumer products could include shampoo, toothpaste, or bottled water.

As mentioned above, the concept of conspicuous consumption is seen in diverse contexts such as history (e.g., Berry, 1994), economics (e.g., Leibenstein, 1950; Veblen, 1899) and sociology (e.g., Bourdieu, 1984). In addition, the marketing literature reveals an increasing level of interest (Truong et al., 2009). However, in the context of the tourism and hospitality industry, only a few studies have been done concerning statusdriven consumption, despite evidence suggesting that travel decisions are mainly moderated by socio-economic status (Correia \& Kozak, 2012; Correia \& Moital 2009; Todd, 2001). For example, Sirgy and Su (2000) coined the term destination conspicuousness which refers to a place where tourists believe they can be observed and/or appraised by significant others. They categorize tourist destinations as 
conspicuous or inconspicuous and argue that tourists' preference for conspicuous destinations tends to be more effected by public self-type self-congruity than by private self-type congruence and vice versa.

This dissertation examined loyal customers' responses to other non-loyal guests in luxury hotels. To establish and design the research background, a concept of conspicuous consumption was adopted. Mainly, the study focused on loyal customers in a luxury hotel market where guest numbers are limited and where there are exclusive amenities such as a membership lounge with a personalized service, provided with the intention of forging a long-term relationship with loyal customers. However, some non-loyal customers also wish to stay in the luxury hotel and to enjoy those amenities. To fulfill this desire, hotels often open the exclusive amenities to other customers through cooperation with third party companies such as credit card companies. Unfortunately, however, such access may cause conflicts between loyal customers and non-loyal customers. Based on this background, for this research, a luxury hotel is considered a suitable place to examine this phenomenon.

\subsection{Intergroup Conflict}

According to Bohm, Rusch, and Baron (2018, p. 34), intergroup conflict is defined as "the perceived incompatibility of goals or values between two or more individuals, which emerges because the involved individuals classify themselves as members of different social groups." The authors also state that group conflict can be caused by such varied sources as value (e.g., high or low), monetary (e.g., money), and political power (e.g., the effect of others' behavior), or it could occur as a result of all of these sources at the same time. In addition, from a psychological point of view, group 
conflict may have an influence on the group members' behavior (e.g., invasion), emotions (e.g., aversion, cowardice) and perceptions (e.g., prejudice, prejudgment) (Bohm et al., 2018). For these reasons, to explain the phenomenon, psychologists and social scientists have associated conflict with particular personality traits (Billig, 1976). Another group of scholars explain this phenomenon by focusing on the distinct nature of intergroup phenomena (Brewer, 1979; LeVine \& Campbell, 1972). Instead of viewing this concept through the lens of psychology, they argue that conflicts are rational and inevitable when groups have incompatible goals and they compete for scarce resources.

In fact, intergroup conflict has developed based on many related theories (Bohm et al., 2018) such as social dominance orientation (Sidanius \& Pratto, 2001), realistic group conflict theory (Sherif, 2015), social identity theory (Tajfel \& Turner, 2001, 2004), integrated threat theory (Stephan \& Stephan, 2013), theory of bounded generalized reciprocity (Yamagishi, Jin, \& Kiyonari, 1999), and theory of parochial altruism (Choi \& Bowles, 2007). Intergroup conflict plays a significant role in the brand tourism effect. For these reasons, this theory helps us to better understand and establish the fundamental situation and background. Even though there are many theories of related group conflict, this study has applied three related theories (i.e., realistic group conflict theory, social identity theory, and integrated threat theory), which constiute the background of this study. 
Table 3

Theories Related to Intergroup Conflict

\begin{tabular}{|c|c|c|}
\hline Related Theories & Researchers & Description \\
\hline Social & Sidanius and & "Group-based hierarchies can be classified by \\
\hline Dominance & Pratto (2001) & age, gender, or more random characteristics \\
\hline \multirow[t]{2}{*}{ Orientation } & & such as race, ethnicity, religious affiliation, and \\
\hline & & sexual orientation" \\
\hline Realistic Group & Sherif (2015) & "Prejudice and discrimination are the result of \\
\hline \multirow[t]{3}{*}{ Conflict Theory } & & competition over limited resources such as \\
\hline & & money, power and social status between \\
\hline & & groups" \\
\hline Social Identity & Tajfel and Turner & "In contrast to the tenets of realistic group \\
\hline \multirow[t]{3}{*}{ Theory } & $(2001,2004)$ & theory, prejudice and discrimination occur \\
\hline & & naturally when individuals categorize someone \\
\hline & & as a member of an out-group" \\
\hline Integrated Threat & Stephan and & "This theory is proposed to explain in-groups' \\
\hline \multirow[t]{3}{*}{ Theory } & Stephan (2000) & perceived or potential threats from out-groups \\
\hline & & (i.e., realistic threat, symbolic threat, negative \\
\hline & & stereotypes and intergroup anxiety)" \\
\hline Theory of & Yamagishi et al. & "In-group members are more likely to \\
\hline Bounded & $(1999)$ & cooperate with each other in order to maintain \\
\hline Generalized & & a positive reputation, so that they can continue \\
\hline Reciprocity & & to benefit from group membership" \\
\hline
\end{tabular}




$\begin{array}{ll}\text { Theory of } & \text { Choi and Bowles } \\ \text { Parochial } & \text { "From the in-group's perspective, collective } \\ \text { Altruism } & \text { action against enemies is a type of public good } \\ & \text { problem. Contributions to the in-group's } \\ & \text { success are costly to the individual (e.g., risk } \\ & \text { of injury or death in violent intergroup } \\ & \text { conflict); however, the outcomes of the } \\ & \text { collective action (i.e., winning or losing an } \\ & \text { intergroup competition) are shared among all } \\ & \text { group members, irrespective of their individual } \\ & \text { contributions" }\end{array}$

Note. Quoted from Bohm et al. (2018).

\subsubsection{Realistic Group Conflict Theory}

Realistic group conflict theory, one of the earliest theories related to intergroup conflict, states that group conflict is inevitable when two groups compete for scarce resources. If one group has a higher success rate for obtaining resources, this circumstance will have a negative influence on group attitudes (Sherif \& Sherif, 1969). These resources might be physical products such as food, or symbolic concepts such as political power (Bobo, 1988). However, the relationship between the two groups might be positive when they work together to achieve a simple common goal (Sherif \& Sherif, 1969).

To test this concept, Sherif and his colleagues (Sherif et al., 1961; Sherif \& Sherif, 1953) conducted a famous social psychological study known as the Robber's Cave Experiment. Participants, who were all young boys, were separated into two teams that 
engaged in many competitive activities such as carrying a canoe through rocky terrain. The team members built a sense of camaraderie by selecting team names and creating flags and t-shirts adorned with the names. The boys were informed that the winning team would be awarded prizes, which led to greater competition and physical violence. To decrease this intense competition, the researchers established ordinate goals that required intergroup cooperation (e.g., repair of the mechanism allowing access to the common drinking water supply). The researchers found that when two groups compete for limited resources, this competition might cause significant intergroup conflict. Even though this experiment garnered some criticism regarding ethical issues and lack of generalizability (e.g., gender and age), this study plays a crucial role in the understanding of the psychology of intergroup conflict.

\subsubsection{Social Identity Theory}

Social identity theorists postulate that people generally define their self-concept by their relationship with social groups (Tajfel \& Turner, 2001, 2004). Social identity can be defined as the perception of belonging to a social group, and it is related to selfesteem. In fact, social identity theory is associated with self-categorization theory (Turner, Hogg, Oakes, Reicher, \& Wetherell, 1987), in which people perceive themselves either as individuals or as group members depending on their current status within the group. In addition, as individuals are likely to categorize other people as "out-group" members and differentiate themselves from these people, they improve their image, which naturally causes prejudice and discrimination. In other words, individuals attempt to find their uniqueness and increase their standing within the group compared to outgroup members. 
This theory presents various strategies that people can follow to achieve positive distinctiveness (Turner et al., 1987). First, when the boundaries of a group are penetrable, members are more likely to use 'individual mobility,' because they want to emphasize more positive differences. In other words, when individuals are able to change group membership, as they differentiate themselves from members of the in-group, they are more likely to achieve their own goals for self-improvement, rather than focusing on accomplishing the aims of their group (Haslam \& Platow, 2001). For example, an individual may look for a new hotel loyalty program, if he or she notices that the current membership provides fewer benefits.

Second, an individual may utilize 'social creativity' strategies, if the current group boundaries are perceived as impermeable and group relations are relatively stable. The lower-status group members may obtain positive distinctiveness if the objective resources of the in-group and the out-group remain unchanged. For example, group members may compare the two groups on a new dimension in which the in-group is more favorable (e.g., one's own company may sell fewer products than the direct market competitor but is more socially and environmentally sustainable) or group members change the comparison standard (e.g., a hotel brand that is less successful in the European market may be competitive in the US market). The last strategy employs social competition when group boundaries are stable, but group relations are not. This tactic differs from social creativity in that the value dimension that shows in-group favoritism can be shared by both in-group members and members of other related social groups. In this strategy, as people compete against out-group members, the relative standing of the in-group increases and their social identity is boosted. Therefore, although the inevitably 
prejudiced results of social comparisons are considered the most conspicuous part of social identity theory, discrimination is likely to occur only in certain circumstances.

Following the long tradition of viewing possessions as an extension of the self (Belk, 1988; Gardner \& Levy, 1955), Bhattacharya and Sen (2003) argue that social identity theory (Tajfel \& Turner, 2001) plays a significant role in explaining the relationship between a company and its customers, specifically the trust that is built regarding a certain company. Social identity theory is useful and effective for describing how the customer brand relationship is sustained. It might explain the relationship between loyal customers and non-loyal customers as well as the relationship between a hotel company and all of its guests.

\subsubsection{Integrated Threat Theory}

Social psychologists Stephan, Ybarra, Martinez, Schwarzwald, and Tur-Kaspa (1998) introduced and developed integrated threat theory by examining theoretical standpoints on intergroup relationships and attitudes of members of in-groups and outgroups based on threats caused by other groups (Rohmann, Florack, \& Piontkowski, 2006). According to Aberson (2015), threats perceived from out-groups are more likely to increase the in-groups' cognitive and affective dimensions of negative attitudes toward out-groups. This theory might help social psychologists to better understand the prejudicial attitudes of out-groups. Due to the fact that members of out-groups are generally socio-culturally different from those in the in-groups, they denote a threat for in-groups. Therefore, integrated threat theory was proposed to explain these types of scenarios. This theory includes four fundamental threats: realistic threats, symbolic

threats, negative stereotypes, and intergroup anxiety (Stephan \& Stephan, 1996). Each of 
these has been shown to be a significant predictor of attitudes toward outgroups, including responses to immigrants, ethnic minorities and nationalities (Stephan, Ybarra, \& Bachman, 1999; Stephan et al., 1998).

The first component, realistic threats, represents real or perceived threats posed by an out-group to an in-group. The threats may comprise actual or perceived social, economic, political, or physical risks to the well-being of members of the in-group. This occurs mainly because of competition for limited resources such as power and jobs. The threats are more likely to be associated with prejudice if the interacting groups have been in conflict. The second component, symbolic threats, involves differences in morals, values, norms, standards, beliefs, and attitudes between the interacting groups and refers to perceived threats to the in-group's worldview. Out-groups might feel threatened when their viewpoints are different from those of the in-group, resulting in mutual resentment. Symbolic threats might occur as a consequence if a belief in the in-group's moral correctness is threatened. They tend to be more closely related to prejudice if the groups are dissimilar in terms of values and practices.

With regard to the third component, intergroup anxiety, Stephan and Stephan (1985), and Stephan, Diaz-Loving, and Duran (2000) argue that people feel threatened and anxious when they face intercultural interactions that cause them to anticipate negative outcomes. Because of these negative attitudes, in-group members dislike outgroup members. Hence, when in-group members fail to have effective interactions with out-group members, it is more likely to be connected with negative attitudes. According to Stephan, et al. (2000), the last component, negative stereotypes, infers threats to the ingroups because it may lead individuals to predict negative results of interactions between in-groups and out-groups. For example, in multinational and multicultural studies, 
negative stereotypes held about people from other countries have been found to emphasize prejudiced attitudes (Stephan \& Stephan, 1996).

As previously mentioned in the section on conspicuous consumption, my study focuses on loyal consumers' responses to non-loyal or general customers and it examines this topic in relation to the bandwagon effect and the snob effect by hypothesizing that loyal customers would want to stay in a hotel with a social group similar to their own and would wish to stay away from general customers. However, general customers also would be likely to want to stay in these luxury hotels and use the many amenities even though they are not loyal consumers. In this vein, group conflict may arise and the third component of intergroup anxiety could be applied to establish the research background. Based on the concept of group conflict and related theories, the study mainly examines the relationship between loyal customers (who have comparably higher loyalty to certain hotel companies) and other customers (who have comparably lower loyalty to certain hotel companies). In addition, this research explores how loyal customers respond to the behaviors of general customers and how this impacts the brand tourism effect.

\subsection{Psychological Ownership}

Pierce et al. $(2001,2003)$ present three important features of psychological ownership. First, this construct illustrates an individual's sense of possessing a material or immaterial object. This feature allows psychological ownership to be differentiated from other concepts, such as organizational commitment and identification (Pierce et al., 2001). Second, psychological ownership involves both a cognitive state such as personal awareness, thought, and belief, and an affective or emotional state. Third, this phenomenon is linked with one's self-concept (Hillenbrand \& Money, 2015; James, 
1950). According to Pierce et al. $(2001,2003)$, when one owns something, the target of possession becomes bonded with the self. Therefore, psychological ownership can be defined as the relationship between an individual and an object, in which the object is experienced as having a close connection with the self (Jussila, Tarkiainen, Sarstedt, \& Hair, 2015).

In terms of psychological ownership, Pierce et al. (2003) argue that people expand their feelings of ownership in the following three ways: (1) assuming control over the object, (2) investing themselves in the object, and (3) knowing the object intimately. The first defines the trait of possession. People have learned that when they control the right to use an object, they can possess it (Furby, 1978). In fact, by picturing themselves using a product, they begin to believe that they control it, which enhances feelings of ownership (Peck, Barger, \& Webb, 2013). The second way is to invest oneself in the object. As people spend more time, energy, and labor on a target, they are more likely to feel a sense of ownership over what they shape, create, or produce (Norton, Mochon, \& Ariely, 2012; Pierce et al., 2003). An investment of psychic energy leads to products that "are regarded as a part of the self because they have grown or emerged from the self" (Belk, 1988, p. 144).

The last way is to become more familiar with an object. People tend to invest themselves by customizing (Franke, Schreier, \& Kaiser, 2010; Moreau, Bonney, \& Herd, 2011) or envisioning intermingling with (Spears \& Yazdanparast, 2014) an object. People generally magnify their feelings of ownership when their target is viewed favorably. Therefore, over time, they become familiar not only with their target's basic features but also with the ways that they believe it differs from other objects of the same type (Pierce et al., 2003). Based on these conceptualizations and definitions, individuals might feel a 
sense of ownership for many different targets, from tangible materials, including mugs (Shu \& Peck, 2011), clothes (Kirk et al., 2018) or digital products (Harwood \& Garry, 2010; Lothian, 2009) to intangible objects, such as other people (Rudmin \& Berry, 1987), ideas (Baer \& Brown, 2012), customer-owned cooperatives (Jussila \& Tuominen, 2010) or restaurant service (Asatryan \& Oh, 2008; Kirk et al., 2018). Likewise, based on prior studies mentioned above, it is found that people perceive their feelings of different ownership depending on the condition of the target and the place. Therefore, this study proposes that psychological ownership could play as a moderator to identify if loyal customers' different perceptions depend on a different level of psychological ownership.

\subsection{Perceived Emotions}

Emotions are referred to Bagozzi, Gopinath, and Nyer (1999, p. 184) as "mental states of readiness that arise from cognitive appraisals of events or one's own thoughts". The authors also argue that emotions normally have a specific referent as when an individual feels anger when service in restaurant is inattentive (Bagozzi et al., 1999). Some previous scholars (Cohen \& Areni, 1991; Oliver, 1997) have attempted to compare emotion with affect to be a general category for mental feeling processes that includes emotions, moods, and attitudes. However, unlike emotion, affect does not have a specific referent (Cohen \& Areni, 1991). Oliver (1997) also indicated that emotion is more likely to be cognitively involved than affect.

This study attempts to examine how loyal customers' emotions are differently perceived depending on two types of non-loyal customers and two different areas in the hotel. In general, hotel rewards programs provide both economic and social benefits (Lee et al., 2015). Loyal customers are more likely to favor the social benefits that cause them 
to feel that they are more selective consumers because they are differentiated from other customers (Truong et al., 2009). Accordingly, if loyal customers believe that their rewards or benefits do not serve this purpose, they might experience negative emotions. As previously stated, this study argues that loyal customers have differing perceptions of the two types of non-loyal customers: brand tourists and brand immigrants. Because tourists who visit the destination have a positive influence on the economic sector, residents might be more willing to welcome them and treat them well.

In contrast, if immigrants come to live in a country, residents may consider them a threat because they perceive them as intruders (Bellezza \& Keinan, 2014). In this vein, it is hypothesized that loyal customers might feel a wide range of emotions depending on the different circumstances. For example, they might feel pride with regard to the former group, and anger or disappointment in connection with the latter. In addition to these two contrasting emotions, the study also explores the possibility of anger, which indicates a higher level of negativity and it attempts to obtain more detailed measures of loyal customers' behavior intention (i.e., intention to remain with the original brand or switching intention) depending on their perception of non-loyal customers (Jang, Cho, \& Kim, 2013).

\subsubsection{Pride}

Pride is derived from satisfaction and fulfillment related to one's achievements and abilities (Cavanaugh, Cutright, Luce, \& Bettman, 2011; Tracy \& Robins, 2004). Mascolo and Fischer (1995, p. 66) succinctly defined pride as, "an emotion generated by appraisals that one is responsible for a socially valued outcome or for being a socially valued person." Many marketing scholars have illustrated this sense of pride in various 
consumption contexts (Norton, Mochon, \& Ariely, 2012; Mukhopadhyay \& Johar, 2009). For example, in the context of branding, researchers have found that brand communities of passionate consumers often develop around prestige brands such as Harley Davidson or Apple whose members are more likely to be involved with the brand community (Decrop \& Derbaix 2010; Fournier \& Lee 2009; Thompson, Rindfleisch, \& Arsel 2006). Based on these prior studies, it seems that loyal customers would feel a sense of pride toward brand tourists, who would reinforce the pride of loyal customers by staying in a luxury hotel that the loyal customers would routinely access as members of a brand community, thereby improving the brand image.

\subsubsection{Anger}

Funches (2016, p. 33) defines consumer anger as "an emotional state which stems from a consumer's perceived loss of entitlement because of an unfair, threatening, or harmful consumption experience involving interactions with the firm, its products or services, and/or its employees." People normally feel anger when they evaluate an event as annoying and hurtful, and such anger can be directed at another person, a firm, or a situation. According to Averill (1983), anger typically stems from a need to restore equity and justice. This situation usually begins with a perceived misdeed against the wronged party who believes that he or she is responding to an occurrence that was unprovoked and unjustified.

Specifically, anger is different from other emotions because it results in a strong urge to respond and requires a tendency to act (Harmon-Jones, Sigelman, Bohlig, \& Harmon-Jones, 2003) by penalizing offenders (Fischer \& Roseman, 2007; Romani, Grappi, \& Bagozzi, 2013). In a consumer situation, companies may pay for these 
tendencies. Diaz and Ruiz (2002) studied the relationship between anger and loyalty in the context of airline delays. Their findings show that anger plays a crucial role in consumer decisions to leave firms. In the hospitality industry, when a loyal customer perceives that the service he or she received from hotel staff does not differ from that of a non-loyal customer, the former may become angry because he or she perceives the situation to be unfair. Therefore, loyal customers' anger plays a significant role in their loyalty to a hotel brand.

\subsubsection{Disappointment}

Zeelenberg (1998) argued that disappointment is derived from the comparison between an obtained outcome and a better outcome that could have resulted from the same choice. That is, people experience disappointment when the actual service delivery fails to meet their expectations (Zeelenberg \& Pieters, 2004), which is likely to lead to goal abandonment (Zeelenberg, van Dijk, Manstead, \& van der Pligt, 2000). With regard to disappointment, van Dijk, van der Pligt, \& Zeelenberg, (1998) examined the patterns of assessment related to diverse negative emotions such as anger, regret, and disappointment. Participants were asked to illustrate an occasion of intense negative emotions and detail the evaluations that were made in these circumstances, on eight dimensions. The result showed that, of many negative emotions, disappointment was highly rated on the dimensions of unexpectedness (cf. Frijda, Kuipers, and Ter Schure, 1989) and circumstantial agency, which can be caused by situations beyond anyone's control. It means that disappointment is more likely to be caused by other-agency than self-agency such as unexpected events or situations (Zeelenberg et al., 2000). 
In the background of this study, the symbolic value of a luxury hotel can be diluted when undesirable groups begin to use the hotel brand (e.g., when non-loyal customers are perceived as brand immigrants). Hence, loyal customers may feel disappointed and give up their preferences for, and stop using, services when these services become associated with undesirable outsiders (e.g., Berger \& Heath, 2007, 2008; White \& Dahl, 2006, 2007).

\subsection{Infringement}

Psychological ownership describes consumers' desire to possess a certain target. Relatedly, territoriality refers to one's attempts to maintain a relationship with a specific target or one's attachment to an object (Brown et al., 2005). In general, individuals are likely to display defensive behavior when they perceive any type of infringement on their territory or possessions. It must be noted that this behavior is often more pronounced when consumers think they possess them exclusively (Brown, 2009). In a related study, Kirk et al. (2018) distinguish between anticipatory and reactionary defenses. The former is caused by a fear of infringement, resulting in consumers displaying irritation regarding the situation. For example, a distraught consumer may block access to an area, on the false pretext that a neighboring seat in a coffee shop is occupied (Brown, 2009; Griffiths \& Gilly, 2012). On the contrary, where reactionary defenses are concerned, consumers may react defensively in response to a negative event, in which negative emotions are expressed (Kirk et al., 2018). Many scholars indicated the use of negative facial expressions to reclaim territory (Brown \& Robinson, 2011) from an individual who is spending a longer amount of time on a public phone even after it becomes apparent that someone else needs to use it (Ruback, Pape, \& Doriot, 1989), or in response to an unsatisfactory experience with a restaurant employee (Ashley \& Noble, 2014). 
In the hospitality industry, this concept has been mainly examined in the context of restaurants. Asatryan and Oh (2008) discovered a relationship between customer participation in service and a sense of psychological ownership of that service. They measured participation by examining aspects such as expression of service preferences, cooperativeness, and leaving feedback that reflects active imposition of the self on the service (including control, knowledge processing, and investment of the self). In addition, Ashley and Noble (2014) examine how customer territoriality can be influenced by the relationships between restaurant employees and customers. For example, the closing time cues employees perform before they actually close the restaurant can cause customers to perceive territorial intrusion and can elicit territorial responses from them. The researchers presented productive cues, withdrawal cues, personal cues, audio/visual cues, hostility cues, and blocking cues. In this way, they found that consumers' identification with the restaurant can amplify the effects of their perception of infringement on their territory.

In the hospitality industry, the hotel lounge, an exclusive area for a limited number of loyal members, can be considered a territory over which loyal customers feel psychological ownership, and thus they may perceive that non-loyal customers are infringing on their territory.

\subsection{Attitude}

In terms of attitude, while earlier studies referred to posture or physical procedure, recent studies mentioned that attitude has become viewed as orientation of mind rather than body and that it can be considered as internal states that might have an effect on apparent behavior (O'Keefe, 2002). To date, attitude has been widely examined by many 
social scientists to anticipate individuals' behavioral intentions based on related theories such as social judgement theory (Carolyn Sherif, Muzafer Sherif, \& Carl Hovland, 1980), theory of reasoned action (Fishbein \& Ajzen, 1975), and theory of planned behavior (Ajzen \& Fishbein, 1980), and these theories and concepts have been used in various contexts such as travel (Ryu \& Jang, 2006), hotel (Han, Hsu \& Sheu, 2010), and online shopping (Hansen, Jensen \& Solgaard, 2004).

Furthermore, the concept of attitude is also utilized to understand and account for individual differences in social behavior. Ajzen (1991, p. 188) revealed that attitude is the most critical determinant of behavioral intention and explained attitude as "the degree to which a person has a favorable or unfavorable evaluation or appraisal of the behavior in question". Attitude toward a behavior is believed to be a function of one's salient or behavioral beliefs, which represent the perceived consequences of the behavior and the evaluation of the significance of the consequences, that is, outcome evaluation (Eagry \& Chailen, 1993).

In addition, in the brand related studies, Aaker (2012) and Keller (2001) explored the impact of the consumer's attitude by considering customer attitudes toward a brand, or brand attitude, as a critical component of brand loyalty. Mitchell and Olson (1981) define brand attitude as an individual's overall evaluation of a brand, or attitude, which mainly depends on a consumer's own perceptions about a brand; attitude has been found to be a reliable predictor of consumer behavior toward brands (Shimp, 2010). Most researchers (e.g., Aaker, 1996; Faircloth, Capella, \& Alford, 2001; Helgeson \& Supphellen, 2004) regard brand image and attitude as distinctive concepts where brand image helps develop potential buyers' overall evaluation or attitude toward a brand. Keller (2001) argues that personal perception regarding typical users of a certain brand 
can be influenced by brand image and brand loyalty. Therefore, this study proposes that loyal customers' attitudes toward other customers closely relate to both brand image and customers' behavioral intentions.

\subsection{Brand Image}

In the luxury market, consumer status and prestige are closely related to the brand image (Fuchs et al., 2013; Park, Milberg, \& Lawson, 1991; Ward \& Dahl, 2014). For this reason, people are more likely to obtain symbolic benefits by consuming goods from a luxury brand, and perceptions of these symbolic benefits influence their attitudes toward brands (Belk, Bahn, \& Mayer, 1982; Keller, 1993, 2009). Many scholars have examined brand image related to attitude (Ryu, Han, \& Kim, 2008). For example, according to prior studies (Baloglu \& Brinberg, 1997; Low \& Lamb, 2000), brand image is "the reasoned or emotional perceptions including their beliefs, ideas, and impressions, which consumers associate with specific brands." Of the wide variety of definitions of brand image expressed by various scholars, Aaker's (1991) and Keller's (1993) conceptualization is the most widely used in the context of brand marketing. They define brand image as "a set of associations organized typically in some meaningful way in a consumer's memory that represents perceptions that may or may not reflect objective reality" (Aaker, 1991, pp. 109-110; Keller, 1993, p. 3). They clearly present a compound structure of brand image that can be summarized with respect to diverse effects or values driven by marketing activities. First, brand image is created when consumers recall information related to a brand, which may be the main reason a customer decides to purchase an item. Second, it is the uniqueness of the brand image that leads to the relationship with the customer and that may differentiate the brand from competitors. 
In branding literature in general, social image and the symbolic meaning of a brand are mentioned as important components for creating brand image (Biel, 1992; Martin \& Brown, 1990). Individuals' perceptions of users of a certain brand can influence the brand image and are considered to be an important component of establishing brand equity and customer loyalty (Keller, 2001). Thus, it can be stated that observers' perceptions on brand user prestige effect observers' beliefs regarding a brand's status and prestige. Lee, Baumgartner, and Winterich (2018) revealed that observers are likely to have more favorable evaluations when the brand's crucial symbolic benefit is improved by luxury brand users (i.e., certain brand users seemed to have high status and prestige). However, on the contrary, observers who desire to identify their high-status and prestigious social image through luxury brand items tend to avoid brands and evaluate them less favorably when the brand consumers do not seem prestigious.

Based on prior studies, just as attitude has an influence on behavior intention, brand image is also related to evaluative attitudes, such as cognitive and emotional loyalty, and it has been shown that there is a significant direct effect between brand image and customer loyalty. In addition, brand image and customer satisfaction have a significant influence on brand loyalty (e.g., Brunner, Stöcklin, \& Opwis, 2008). However, another result mentioned that the effect of brand image on brand loyalty is even more significant when customer satisfaction is not considered (e.g., Hart \& Rosenberger, 2004). Brand image has been widely studied in the hospitality and tourism field. For example, Ryu et al. (2008) have explored the effect of food quality on restaurant brand image, customer satisfaction and brand loyalty. According to Castro, Armario, and Ruiz (2007), when tourists are satisfied with a destination's service quality, 
this will increase brand loyalty revisit intention. Cretu and Brodie (2007) examine the effect of brand image and company reputation on customer perceived service quality, brand value, and customer loyalty in a business market, the results of which indicate that brand image has a positive effect on customer perceived value.

\subsection{Behavioral Intention}

Many scholars (McAlexander, Kim, \& Roberts, 2003; Oliver, 1999; Petrick, 2004) have focused on the value of behavior intention particularly during the last decades. They describe this concept as a customer's repeat consumption behavior or revisit intention that includes an emotional commitment or expression of a positive attitude toward the service provider. Basically, marketers provide better prices and promotions in an attempt to encourage their loyal customers to visit more frequently and consume more products than their non-loyal customers. Then, loyal customers become less likely to switch to their competitors and more likely to share their positive experiences with others. Because of customer loyalty, organizations can save money on marketing activity (Haywood, 1988; Oliver, 1999; Petrick, 2004; Shoemaker \& Lewis, 1999). Petrick (2004) argues that repeat customers are more than just a secure economic source, they can also be information channels that casually create links to their friends, relatives, colleagues, and other probable consumers and thus enable a business to uphold a clientele base.

Even though numerous marketers in diverse industries are already aware of the positive effects of brand loyalty on successful businesses, many scholars have just begun to analyze this concept through diverse approaches and tactics. In addition, their focus on this topic has enabled them to study various areas and industries both theoretically and 
empirically. In the early stages, loyalty studies were limited to customers' intention to revisit or repurchase. However, this field has evolved appreciably and subsequent scholars have begun to view the customers' psychological attachment to the service provider or the brand as an important aspect (Sheth \& Parvatiyar, 2000). Overall, loyalty has been perceived as a multi-dimensional construct and research in this area has shown immense development (Bowen \& Chen, 2001).

Previous researchers (Aaker, 2001; Keller, 1993; Faircloth et al., 2001) have revealed a positive association between attitude and loyalty toward a brand. Another related link has been discovered between brand image and brand loyalty (e.g., Chaudhuri \& Holbrook, 2001). Prominent scholars in the context of brand management, Aaker (2001) and Keller (1993) argue that brand loyalty is a consequence of efficiently managing acquaintance and experience regarding a brand image and attitude. Therefore, both brand image and the customer's attitude toward a brand could significantly impact brand loyalty (Faircloth et al., 2001). Based on the numerous brand related research studies, this study focuses on customers' behavioral intention in certain situations when non-loyal customers cause loyal customers to perceive infringement. As mentioned above, non-loyal customers are divided into brand tourists and brand immigrants and it is hypothesized that loyal customers might have different opinions depending on whether they perceive non-loyal customers as brand tourists or brand immigrants. According to Bellezza and Keinan (2014), when non-loyal customers are perceived as brand tourists, people might expect to have comparably more positive experiences with them than if they perceive them as brand immigrants.

On the contrary, in terms of psychological ownership, many scholars have studied diverse circumstances including targets of ownership (e.g., coffee, artistic design, 
sweaters, pizza), infringement on others (e.g., other customers, service providers), and consumption contexts (e.g., a restaurant, a retail store, a sidewalk cafe, and an open-air market). In addition to responses to territorial behavior, there are likely to be emotional responses on the part of the consumer. For example, perceived infringement is likely to trigger negative affective responses, which may occur prior to, during, or after any territorial responses and could increase loyal customers' negative emotions (Brown \& Robinson, 2011) and could lead to abandonment of the territory (Brown et al. 2005), negative word of mouth (Ashley \& Noble, 2014) and switching behavior (Kirk et al., 2018). Therefore, the current study focuses more on a conflict between customers and refers a switching intention, negative behavior intention.

\subsection{Summary}

Based on the existing theoretical and empirical background, a conceptual framework was proposed and tested to investigate the various effects of the loyal customers' emotions, infringement, attitude, brand image, and brand loyalty depending on whether they perceive non-loyal customers as brand tourists or brand immigrants. From findings of previous studies, this current study expected that following loyal customers' perceptions of non-loyal customers, loyal customers' perceived infringement, attitude toward non-loyal customers, brand image and switching intention would impact one another depending on the types of non-loyal customers and places divided by psychological ownership. 


\subsection{Hypotheses}

Based on reviewing the previous literature, the following hypotheses are proposed:

Hypothesis 1: Loyal customers' emotions (i.e., pride, disappointment, and anger), infringement, attitude, brand image, and switching intention perceived by or toward nonloyal customers will be different depending on whether or not they are perceived as brand tourists or immigrants.

H1a: Loyal customers will perceive higher levels of pride toward brand tourists than brand immigrants.

H1b: Loyal customers will perceive higher levels of disappointment toward brand immigrants than brand tourists.

H1c: Loyal customers will perceive higher levels of anger toward brand immigrants than brand tourists.

H1d: Loyal customers will perceive a higher rate of infringement toward brand immigrants than brand tourists.

H1e: Loyal customers will have more positive attitudes toward brand tourists than brand immigrants.

H1f: Loyal customers' perceived brand image will be different depending on whether non-loyal customers are perceived as brand tourists or brand immigrants.

H1g: Loyal customers will perceive higher switching intention due to the presence of brand immigrants rather than brand tourists. 
Hypothesis 2: Psychological ownership will have a significant moderating effect on the relationship between the types of non-loyal customers and loyal customers' perceived emotions (i.e., pride, disappointment, and anger), infringement, attitude, brand image, and switching intention.

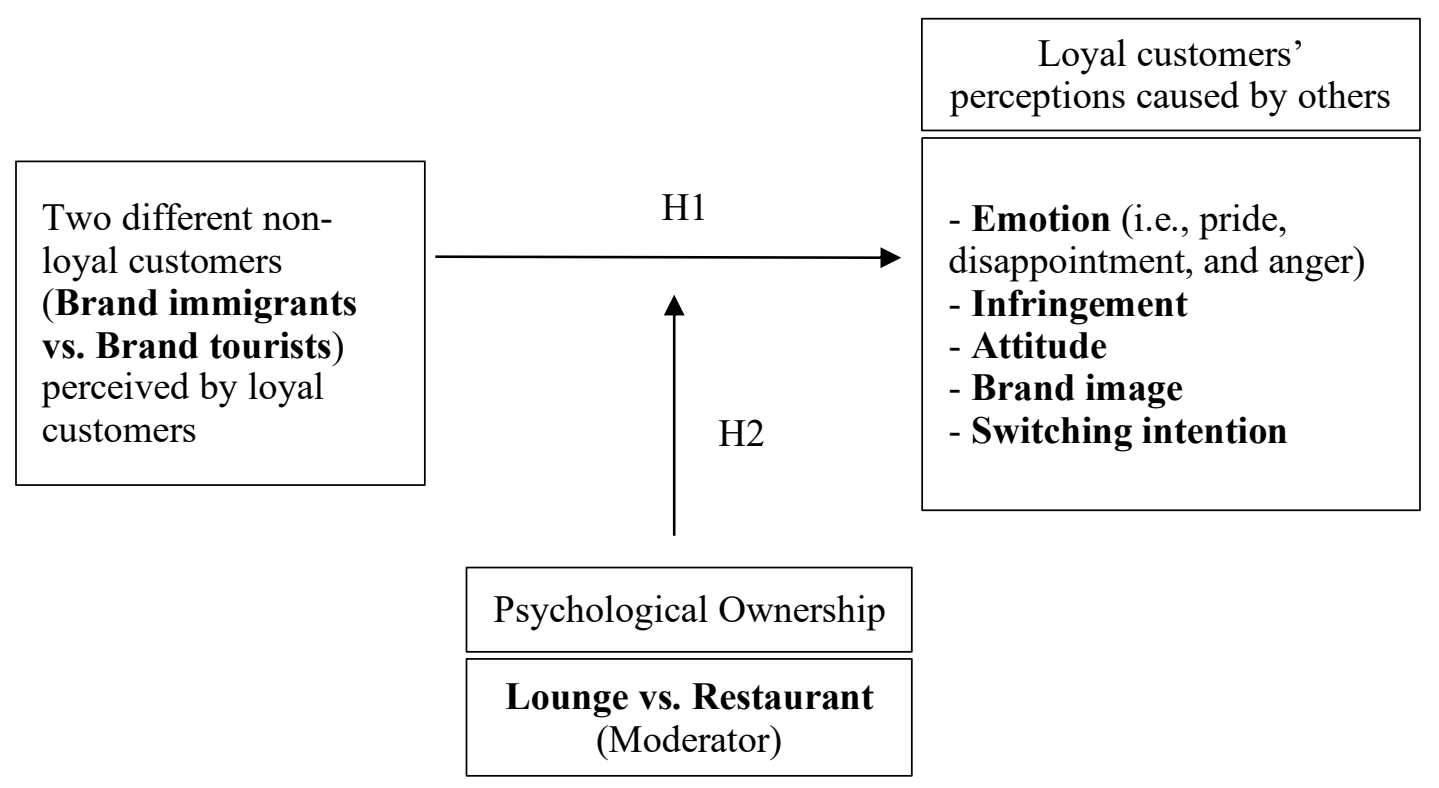

Figure 2. Framework for the examining differences of loyal customers' perceptions of other customers. 
Hypothesis 3: When loyal customers view non-loyal customers as brand immigrants, their perceptions (i.e., infringement, attitude, brand image, switching intention) toward them will be impacted.

H3a: When loyal customers view non-loyal customers as brand immigrants, their infringement will have a negative impact on attitude.

H3b: When loyal customers view non-loyal customers as brand immigrants, their infringement will have a negative impact on brand image.

H3c: When loyal customers view non-loyal customers as brand immigrants, their infringement will have a positive impact on switching intention.

H3d: When loyal customers view non-loyal customers as brand immigrants, their attitude will have a positive impact on brand image.

H3e: When loyal customers view non-loyal customers as brand immigrants, their attitude will have a positive impact on switching intention.

H3f: When loyal customers view non-loyal customers as brand immigrants, their brand image will have a negative impact on switching intention.

Hypothesis 4: When loyal customers view non-loyal customers as brand tourists, the relationship among loyal customers' perceptions (i.e., infringement, attitude, brand image, switching intention) toward non-loyal customers will be impacted.

H4a: When loyal customers view non-loyal customers as brand tourists, their infringement will have a positive impact on attitude.

H4b: When loyal customers view non-loyal customers as brand tourists, their infringement will have a negative impact on brand image. 
H4c: When loyal customers view non-loyal customers as brand tourists, their infringement will have a positive impact on switching intention.

H4d: When loyal customers view non-loyal customers as brand tourists, their attitude will have a positive impact on brand image.

H4e: When loyal customers view non-loyal customers as brand tourists, their attitude will have a positive impact on switching intention.

H4f: When loyal customers view non-loyal customers as brand tourists, their brand image will have a negative impact on switching intention.

Hypothesis 5: When non-loyal customers are viewed as brand immigrants, the relationship among loyal customers' perceptions (i.e., infringement, attitude, brand image, switching intention) toward non-loyal customers will be impacted differently depending on the location (i.e., lounge vs. restaurant).

H5a: When loyal customers see brand immigrants in the lounge, the effect of infringement on attitude will be higher than in the restaurant.

H5b: When loyal customers see brand immigrants in the lounge, the effect of infringement on brand image will be higher than in the restaurant.

H5c: When loyal customers see brand immigrants in the lounge, the effect of infringement on switching intention will higher than in the restaurant.

H5d: When loyal customers see brand immigrants in the lounge, the effect of attitude on switching intention will be higher than in the restaurant.

H5e: When loyal customers see brand immigrants in the lounge, the effect of attitude on brand image will be higher than in the restaurant. 
H5f: When loyal customers see brand immigrants in the lounge, the effect of brand image on switching intention will be higher than in the restaurant.

Hypothesis 6: When loyal customers view non-loyal customers as brand tourists, the relationship among loyal customers' perceptions (i.e., infringement, attitude, brand image, switching intention) will be different depending on the location (i.e., lounge vs. restaurant).

H6a: When loyal customers see brand tourists in the lounge, the effect of infringement on attitude will be higher than in the restaurant.

H6b: When loyal customers see brand tourists in the lounge, the effect of infringement on brand image will be higher than in the restaurant.

H6c: When loyal customers see brand tourists in the lounge, the effect of infringement on switching intention will be higher than in the restaurant.

H6d: When loyal customers see brand tourists in the lounge, the effect of their attitude on switching intention will be higher than in the restaurant.

H6e: When loyal customers see brand tourists in the lounge, the effect of their attitude on brand image will be higher than in the restaurant.

H6f: When loyal customers see brand tourists in the lounge, the effect of brand image on their switching intention will be higher than in the restaurant. 


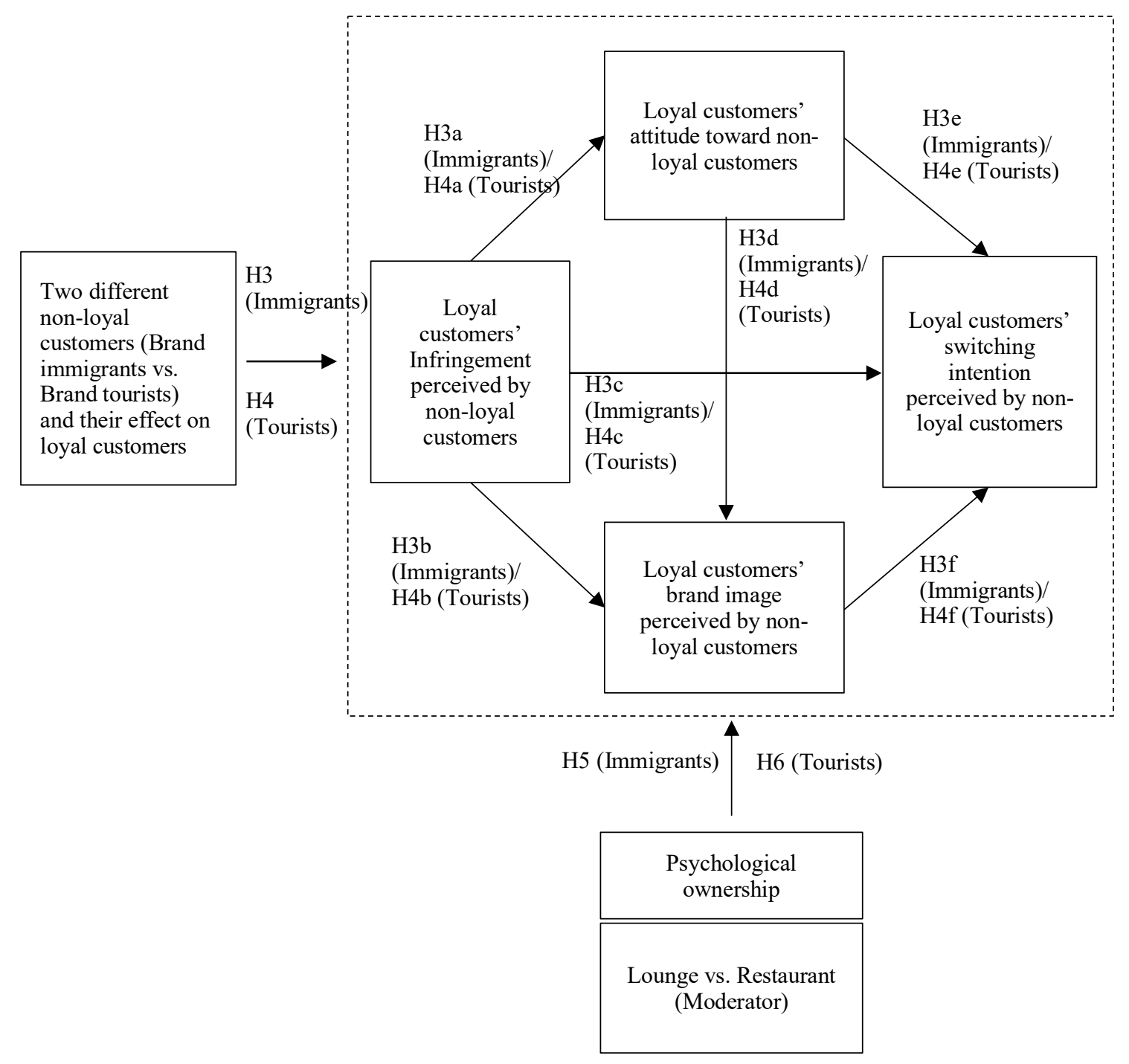

Figure 3. Research proposed model. 


\section{CHAPTER 3}

\section{METHODOLOGY}

\subsection{Introduction}

This chapter will discuss the methodology which is employed to achieve the research purposes. The first section contains a description of the research design including how written scenarios were created and how the experimental conditions were manipulated. The second section includes an explanation of instrument development followed by the process and results of the pre-test for the primary test in section three. In section four, the target population and sampling technique will be discussed. These are followed by the data-collection method, including the review process by the Campus Institutional Review Board. Lastly, in section five, the data analysis including statistical procedures will be explained.

\subsection{Research Design}

The purpose of this study was to examine the brand tourism effect that is so prevalent in the hospitality industry. The experimental design included two types of nonloyal customers (i.e., brand immigrants and brand tourists) as between subject variables and two different areas to study the effect of psychological ownership within subject variables. In order to examine the effect of non-loyal customers' behaviors on loyal customers' perceptions, as mentioned above, a mixed-subject design was applied. In this study, loyal customers' different perceptions of two types of non-loyal customers and two different scenarios were used as independent variables and three elements of loyal 
customers' perceived emotions (i.e., anger, disappointment, and pride), attitude, brand image, and loyal customers' switching intention were the dependent variables.

Since this study attempted to investigate one specific phenomenon, the brand tourism effect in luxury hotels, the study presented two different and distinguishable scenarios to make participants clearly understand through description and instruction. The objective of the scenario was to create a situation and atmosphere that would help the respondents understand the study. This research employed a 2 (two types of non-loyal customers: brand immigrants and brand tourists) $\times 2$ (areas divided by psychological ownership: lounge vs. restaurant) mixed experimental design on the dependent variables (i.e., emotions, infringement, attitude, brand image, and switching intention). Loyal customers were first asked to read an instruction and description, and imagine the situation that the survey presented. Then, loyal customers were asked to answer questions regarding their opinions about these two types of non-loyal customers. They were also asked some questions regarding their opinions about the hotel lounge where guests have been found to perceive a high level of infringement and the hotel restaurant that had not been associated with these feelings.

\subsection{Manipulation}

This study attempted to manipulate participants with the least amount of activation related to the memory system. This is because triggering their memories would activate the participants' biases or previously existing attitudes toward certain places or people. Theoretically, the information processing of the scenarios requires participants to encode information from the scenarios into their working memory and to store it in longterm memory, where they can retrieve it later on during evaluation and decision-making 
tasks. The motivational relevance of each scenario is vital for participants to automatically allocate their limited resources to information processing and ultimately to form attitudes and behavioral intentions (e.g., Dijksterhuis \& Bargh, 2001). Therefore, this current study tried to avoid triggering the participants' existing memories. Another area that offers room for inquiry is whether or not these scenarios exist at certain levels (e.g., loyal customers and non-loyal customers; brand immigrant and brand tourist).

Before the main study, in order to determine if the manipulation of the independent variable has the intended effect, this study attempted to perform a manipulation check in a pretest. Since this study involves instructions and scenarios that explain the situation and background of the study, in the pretest, the questionnaire was about the scenario. To be specific, the intention was to check whether two non-loyal customers (i.e., brand immigrants and brand tourists) can be clearly differentiated. The example question was 'I felt like the scenario I read was realistic'. In addition, based on psychological ownership, two different locations in the luxury hotel environment are determined. The first location is a membership lounge. Since loyal customers might consider this place as their exclusive area, they might perceive a threat to psychological ownership from general customers who are not supposed to enter. The second location is the hotel restaurant where everyone including hotel guests and general restaurant visitors are welcome. Observing customer behavior in these two different locations will reveal the effect of psychological ownership. The pretest examined whether customers can clearly perceive different levels of psychological ownership between the lounge and the restaurant. In pretest, participants were asked to answer the questions regarding manipulation. The example question was 'I felt like the lounge I stayed at was 'my group's own area'. 


\subsection{Variables Measured}

When the respondents were ready to begin, they received the instruction, "Please read the following scenario carefully and provide your explanation." Through the description aforementioned, the participants were asked to imagine that they are staying at a luxury hotel and, as a loyal customer, they are eligible to access all of amenities the hotel provides. Then, they were randomly allocated either a scenario presenting the situation in which they see brand immigrants or a scenario presenting the situation in which they see brand tourists. While they were taking the survey, they were presented with two scenarios: the hotel club lounge and the restaurant in a luxury hotel. The participants were then asked questions designed to gage their perceptions regarding nonloyal customers.

All multi-item variables were adopted from the existing literature and measured using a 7-point Likert scale, which is a relatively common method for reflective constructs in survey research. This method is widely used in the social sciences due to the fact that the greater number of response options (compared to the 5-point Likert scale) generally provides more accurate assessments in psychometric studies - as long as those options are not overwhelming (Nunnally, 1978). It also offers higher sensitivity and better discrimination between respondents. With a 7-point Likert scale, respondents are less inclined to simply tick the middle score as they are offered a wider variety of answers (Dawes, 2008).

As shown in the Table 4, the questions were adapted from many prior studies (e.g., Ashley \& Noble 2014; Bellezza \& Keinan, 2014; Kirmani, Sood, \& Bridges, 1999; Jang et al., 2013). The three items used to gage emotion (i.e., pride, disappointment, and 
anger) were derived from Bellezza and Keinan (2014) and Jang et al. (2013) and the three items used to measure infringement were adapted from Ashley and Noble (2014). The three items used to gage brand image were derived from Kirmani et al. (1999), The three items designed to measure attitude were adapted from Bellezza and Keinan (2014), finally, the three items used to gage loyalty and the three items used for measuring switching intention were adapted from Jang et al. (2013). In this survey questionnaire, in order to suit questions to the background of this study, the items are slightly modified. The questionnaire also includes questions designed to gather participants' demographic information including gender, age, income, family structure, and race. All variables and questions used in this study are presented in Appendix C.

\section{Table 4}

Constructs and References

\begin{tabular}{|c|c|c|}
\hline \multicolumn{2}{|l|}{ Construct } & \multirow{2}{*}{$\begin{array}{l}\text { References } \\
\text { Bellezza and Keinan (2014) }\end{array}$} \\
\hline Emotion & Anger (1 item) & \\
\hline & & Jang, Cho and Kim (2013) \\
\hline \multirow{2}{*}{\multicolumn{2}{|c|}{ Disappointment (1 item) }} & Bellezza and Keinan (2014) \\
\hline & & Jang, Cho and Kim (2013) \\
\hline \multirow{2}{*}{\multicolumn{2}{|c|}{ Pride (1 item) }} & Bellezza and Keinan (2014) \\
\hline & & Jang, Cho and Kim (2013) \\
\hline \multicolumn{2}{|c|}{ Infringement ( 3 items) } & Ashley and Noble (2014) \\
\hline \multicolumn{2}{|c|}{ Attitude (3 items) } & Bellezza and Keinan (2014) \\
\hline \multicolumn{2}{|c|}{ Brand image ( 3 items) } & Kirmani, Sood and Bridges (1999) \\
\hline \multicolumn{2}{|c|}{ Switching intention (3 items) } & Jang, Cho and Kim (2013) \\
\hline
\end{tabular}




\subsection{Data Collection and Sampling}

Before the main study began, a pretest was conducted. One hundred and twenty college students in the Midwest area participated in the pretest to check the realism of the scenario and the manipulation of the study background. After the pretest, in the main study, participants were required to be at least 18 years old and had to be resident in the U.S. In addition to these requirements, luxury consumers were recruited. Basically, all respondents had annual household incomes of more than $\$ 100,000$ and they were familiar with luxury brands and had purchased luxury products (both goods and hospitality services). According to Danziger (2011), these consumers can be grouped into two basic categories: "ultra-affluent" consumers, with annual household incomes of more than $\$ 250,000$ and "high earners not rich yet," with annual household incomes between $\$ 100,000$ and $\$ 249,999$. According to a luxury tracking report from Unity Marketing (2012), ultra-affluent consumers represent the top $2 \%$ of households in the United States.

After the selection process, an online survey company randomly distributed the survey questionnaire to its panel members. Research Now, a well-known online survey company, was used to recruit U.S. adult participants online. Participants recruited by this company are more demographically diverse and represent a closer approximation of the actual U.S. population than standard Internet samples. They are also significantly more diverse than typical American college undergraduate samples (e.g., Buhrmester, Kwang, \& Gosling, 2011; Paolacci, Chandler, \& Ipeirotis, 2010). There are practical advantages to using Research Now in terms of subject anonymity, identifiability and prescreening, and subjective identifiability. 
Respondents were required to have an IP address within the United States, and to be at least 18 years of age. The survey company was able to reach a large audience and to secure rapid replies. The online survey was open from April 16 to April 30, 2018. It took participants approximately 10 minutes on average to fill out the questionnaires. The initial survey questionnaire containing the entire set of measures for all study variables was composed of three major parts (i.e., a detailed description of the study, questions for study constructs, and demographic questions).

Finally, 1,000 adults from an online panel in the United States were selected. The sample size was larger than the acceptable number for PLS-SEM models and therefore was considered appropriate. After eliminating incomplete responses and outliers, 33 unusable surveys were rejected and 967 remained for data analysis. According to the literature (e.g., Gefen, Straub, \& Boudreau, 2000; Kline, 2011), a target sample size of over 200 responses is considered large, thus validating the size of the target sample for this study.

\subsection{Data Analysis}

In order to achieve the objectives of this study, and to test the hypotheses, multivariate analysis of variance (MANOVA), and Partial Least Squares-Structural Equation Model (PLS-SEM) were performed with SPSS 23.0 and SmartPLS 2.0. First, the study conducted the MANOVA test to examine the differences in loyal customers' perceptions of emotion (i.e., pride, disappointment, anger), infringement, attitude, brand image, and switching intention toward non-loyal customers. Second, this study performed PLS-SEM to test the relationship among study variables including infringement, attitude, brand image, and switching intention perceived by non-loyal customers. 
Data collection and examination

Stage 3

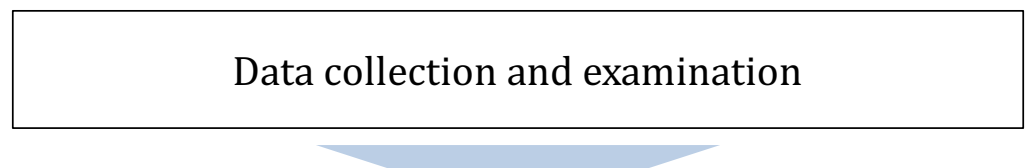

Stage 4

PLS path model estimation

Stage 5a

Assessing PLS-SEM results of the reflective measurement models

Stage $5 b$

Assessing PLS-SEM results of the formative measurement models

Stage 6 Assessing PLS-SEM results of the structural model

Figure 4. PLS-SEM procedures.

Note. Adopted from Hair, Hult, Ringle, and Sarstedt. (2016) 

model relationships

Step 3

Assess the level of $\mathrm{R}^{2}$

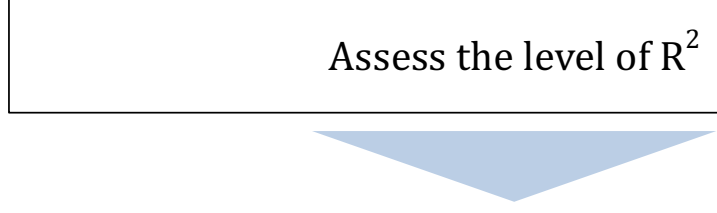

Step 4

Assess the effect sizes of $\mathrm{f}^{2}$

Step 5

Assess the predictive relevance $Q^{2}$

Figure 5. Structural model assessment procedure.

Note. Adopted from Hair et al. (2016).

\subsection{Summary}

In this chapter, the methodology utilized to achieve the goals of this research is presented. The research design described and explained how its experimental conditions were developed. The manipulation section proved how the scenarios for the experiment were realistic and the variable section presented how the research variables were utilized in the survey questions. Finally, in the data-collection section, the study explained the process and procedures for data analysis. 


\section{CHAPTER 4}

\section{RESULTS}

\subsection{Introduction}

This chapter includes all relevant findings of this study and describes the data analysis used in this study. MANOVA (multivariate analysis of variance) was utilized to process the results of the loyal customers' responses (i.e., emotions, infringement, attitude, brand image, and behavior intention) to their perceptions of whether non-loyal customers were brand tourists or brand immigrants and their relationship with psychological ownership of the hotel lounge and restaurant. The second section includes the results of the PLS-SEM (Partial Least Squares - Structural Equation Model) to explore the relationships among the study variables (i.e., emotion, infringement, attitude, brand image, and brand loyalty) in response to whether loyal customers perceived nonloyal customers to be brand tourists or brand immigrants.

\subsection{Sample and Design}

During the first stage of the survey process, demographic information, this study collected data regarding the participants including gender, age, educational background, annual income and family structure. In the second part, diverse data about participants' travel related information including number of loyalty programs with which they were involved, frequency of travel per year, and purpose of travel were collected. Table 5 shows the results for the descriptive analysis.

The frequency analysis displays the distributions of the respondents' demographics and customer profiles. We received a total of 967 usable responses. For 
loyalty program, $66.4 \%$ respondents $(\mathrm{N}=642)$ answered they are involved in at least one loyalty program. Of these loyalty program members, $38.5 \%$ respondents $(\mathrm{N}=247)$ were in one loyalty program and $27.6 \%$ respondents $(\mathrm{N}=177)$ joined two loyalty programs. In this study, $34 \%$ respondents $(\mathrm{N}=329)$ took trips 2 to 3 times annually and $25.5 \%(\mathrm{~N}=247)$ traveled 4 to 5 times yearly. More than $70 \%$ of respondents $(\mathrm{N}=693,71.7 \%)$ answered leisure travel as their main purpose of trip.

In terms of demographics, the age range of the sample was 18 to 72 years, with approximately $26.6 \%$ in the $28-37$ age bracket. Gender was almost equally distributed at $48.7 \%$ male $(n=471)$ and $51.3 \%$ female $(n=496)$. The largest percentage of respondents (24.0\%) reported a range between $\$ 150,000$ and $\$ 199,999$, while the second largest percentage of respondents, approximately $15 \%$, reported an annual household income of between $\$ 100,000$ and $\$ 149,999$. In terms of participants' educational background, the largest group was those with bachelor's degrees (40.0\%), followed by graduate-degree holders and those with post-graduate qualifications (31.1\%). In this study, all of the participants had an income greater than $\$ 100,000$.

Table 5

Demographic and Personal Information

\begin{tabular}{lll}
\hline Item & $\#$ & $\%$ \\
\hline Loyalty program $(\mathrm{N}=967)$ & & \\
Yes & 642 & 66.4 \\
No & 325 & 33.6 \\
& & \\
\# of loyalty programs $(\mathrm{N}=642)$ & & \\
1 & 247 & 38.5 \\
2 & 177 & 27.6 \\
3 & 117 & 18.2 \\
\hline
\end{tabular}




\begin{tabular}{|c|c|c|}
\hline $4-5$ & 64 & 10.0 \\
\hline Greater than 6 & 16 & 2.5 \\
\hline Decline to answer & 21 & 3.3 \\
\hline \multicolumn{3}{|l|}{ Annual travel frequency $(\mathrm{N}=967)$} \\
\hline $0-1$ & 111 & 11.5 \\
\hline $2-3$ & 329 & 34.0 \\
\hline $4-5$ & 247 & 25.5 \\
\hline $6-7$ & 118 & 12.2 \\
\hline $8-9$ & 49 & 5.1 \\
\hline Greater than 10 & 113 & 11.7 \\
\hline \multicolumn{3}{|l|}{ Trip purpose $(\mathrm{N}=967)$} \\
\hline Business travel & 173 & 17.9 \\
\hline Leisure & 693 & 71.7 \\
\hline Friend and relatives & 96 & 9.9 \\
\hline Others & 5 & .5 \\
\hline \multicolumn{3}{|l|}{ Education background $(\mathrm{N}=967)$} \\
\hline High school or less & 60 & 6.2 \\
\hline Some college or associated degree (two-year) & 219 & 22.6 \\
\hline Bachelor (four-year) & 387 & 40.0 \\
\hline (Post) Graduate studies & 301 & 31.1 \\
\hline \multicolumn{3}{|l|}{ Gender $(\mathrm{N}=967)$} \\
\hline Male & 471 & 48.7 \\
\hline Female & 496 & 51.3 \\
\hline \multicolumn{3}{|l|}{ Annual income $(\mathrm{N}=967)$} \\
\hline $100,000-149,999$ & 574 & 59.4 \\
\hline $150,000-199,999$ & 232 & 24.0 \\
\hline $200,000-249,999$ & 65 & 6.7 \\
\hline $250,000-299,999$ & 37 & 3.8 \\
\hline $300,000-349,999$ & 16 & 1.7 \\
\hline$>350,000$ & 36 & 3.7 \\
\hline
\end{tabular}




\begin{tabular}{lll}
\hline Age $(\mathrm{N}=967)$ & & \\
$18-27$ (Millennial) & 130 & 13.4 \\
$28-37$ (Millennial) & 257 & 26.6 \\
$38-45($ Gen-X) & 164 & 17.0 \\
$46-53($ Gen-X) & 164 & 17.0 \\
$54-62$ (Baby boomer) & 183 & 18.9 \\
$63-72$ (Baby boomer) & 69 & 7.1 \\
\hline
\end{tabular}

\subsection{Realism and Manipulation Check}

To ensure the realism of the scenarios, all mean value perceptions of brand immigrants: $(M=5.61, S D=1.08)$ and brand tourists $(M=5.31, S D=1.27)$ were checked by 120 college students in the Midwest area, and were found to score higher than 5.0 on a seven-point semantic differential scale. The results mean that participants considered the scenarios to be realistic and appropriate for the study. In addition, the participants were also asked to answer how this affects perceived psychological ownership depending on the location (hotel restaurant: $M=3.00, S D=1.43$; hotel lounge $(M=5.07, S D=1.55)$ (See Table 6.). The result revealed that participants scored lower than 5.0 for restaurant, while they scored higher than 5.0 for lounge. According to the result of the t-test, participants significantly confirmed that in a hotel lounge, they are more likely to perceive psychological ownership than in a hotel restaurant. This outcome indicated that restaurant and lounge can be distinguished by level of psychological ownership. 
Table 6.

Perceived psychological ownership of a lounge and a restaurant

\begin{tabular}{lllll}
\hline Lounge & Restaurant & Mean difference & t-value & p-value \\
\hline $5.07(1.55)$ & $3.0(1.43)$ & 2.07 & 7.601 & $.000^{* * *}$
\end{tabular}

Note. Standard deviations are in parentheses.

Note. $* * * p<.001$

\subsection{Loyal customers' Perceived Emotions and Their Effect on Psychological Ownership}

In order to examine hypotheses 1 and 2 , the study analyzed the data using a twoway MANOVA test, with the types of non-loyal customers and psychological ownership as the independent variables and the loyal customers' emotions (i.e., anger, disappointment, and pride) regarding non-loyal customers as the dependent variables. Tables 7 and 8 present the multivariate and univariate results of this test, the first result of two-way MANOVA for the dimension of anger revealed a significant difference between the two types of non-loyal customers $(F(1,1918)=24.023, \mathrm{p}<.001, \eta 2=.012)$ and two different backgrounds $(\mathrm{F}(1,1918)=87.260, \mathrm{p}<.001, \eta 2=.044)$. We also found a significant two-way interaction with psychological ownership $(\mathrm{F}(1,1918)=4.933, \mathrm{p}<$ $.05, \eta 2=.003)$. The second MANOVA result for the feeling of disappointment suggested that the main effect of loyal customers' perceptions of non-loyal customers $(\mathrm{F}(1,1918)=$ $32.344, \mathrm{p}<.001, \eta 2=.017)$ and psychological ownership $(\mathrm{F}(1,1918)=96.72, \mathrm{p}<.001$, $\eta 2=.048)$ was significant. Our analysis revealed a significant two-way interaction with psychological ownership $(\mathrm{F}(1,1918)=5.268, \mathrm{p}<.05, \eta 2=.003)$. The third MANOVA results for pride indicated significant differences between the two types of non-loyal customers $\left(F(1,1918)=25.964, p<.001, \eta^{2}=.013\right)$ and the two different backgrounds 
$\left(\mathrm{F}(1,1918)=15.717, \mathrm{p}<.001, \eta^{2}=.008\right)$. We also found a noteworthy two-way interaction with psychological ownership $(\mathrm{F}(1,1918)=4.552, \mathrm{p}<.01, \eta 2=.002)$.

Table 7.

Results of Two-Way MANOVA for Loyal Customers'Emotions (Multivariate Results)

\begin{tabular}{lllll}
\hline Source & Wilk's & $\mathrm{F}$ & $\mathrm{p}$ & $\eta 2$ \\
\hline Intercept & .064 & 9310.387 & .000 & .936 \\
Psychological ownership & .941 & 39.960 & .000 & .059 \\
Types of non-loyal customers & .970 & 19.692 & .000 & .030 \\
Psychological ownership $\times$ & .995 & 3.491 & .015 & .005 \\
Types of non-loyal customers & & & & \\
\hline
\end{tabular}

Table 8.

Two-Way MANOVA Results for Dependent Variables

\begin{tabular}{lllllll}
\hline Source & SS & df & MS & F & $p$ & $\eta^{2}$ \\
\hline Anger & & & & & & \\
$\quad$ Types of non-loyal customers & 75.988 & 1 & 75.988 & 24.023 & $\mathbf{. 0 0 0 * * *}$ & .012 \\
Psychological ownership & 276.008 & 1 & 276.008 & 87.260 & $\mathbf{. 0 0 0 * * *}$ & .044 \\
Types of non-loyal customers $\times$ & 15.603 & 1 & 15.603 & 4.933 & $\mathbf{. 0 2 6 *}$ & .003 \\
Psychological ownership & & & & & & \\
Error & 6066.749 & 1918 & 3.163 & & & \\
Total & 35624.000 & 1922 & & & & \\
Disappointment & & & & & & \\
Types of non-loyal customers & 98.889 & 1 & 98.889 & 32.344 & $\mathbf{. 0 0 0 * * *}$ & .017 \\
\hline
\end{tabular}




\begin{tabular}{lllllll}
\hline Psychological ownership & 295.260 & 1 & 295.260 & 96.572 & $\mathbf{. 0 0 0 * * *}$ & .048 \\
Types of non-loyal customers $\times$ & 16.105 & 1 & 16.105 & 5.268 & $\mathbf{. 0 2 2 *}$ & .003 \\
Psychological ownership & & & & & & \\
Error & 5864.119 & 1918 & 3.057 & & \\
Total & 37841.000 & 1922 & & & & \\
Pride & & & & & & \\
Types of non-loyal customers & 61.111 & 1 & 61.111 & 25.964 & $\mathbf{. 0 0 0 * * *}$ & .013 \\
Psychological ownership & 36.992 & 1 & 36.992 & 15.717 & $\mathbf{. 0 0 0 * * *}$ & .008 \\
Types of non-loyal customers $\times$ & 10.713 & 1 & 10.713 & 96.572 & $\mathbf{. 0 3 3 *}$ & .002 \\
Psychological ownership & & & & & & \\
Error & & & & & & \\
Total & 4514.340 & 1918 & 2.354 & & & \\
\hline
\end{tabular}

Note. ${ }^{*} \mathrm{p}<.05, * * * \mathrm{p}<.001$

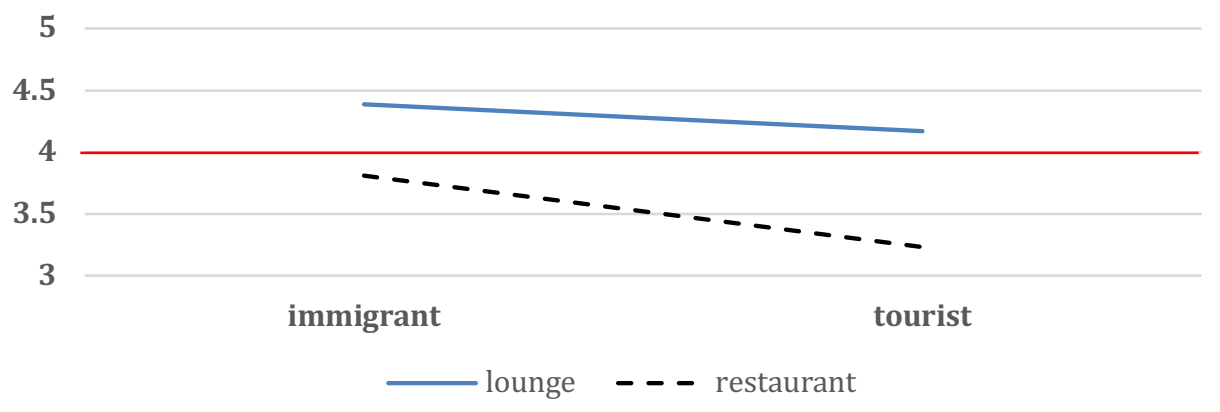

Figure 6. Interactions of the type of non-loyal customers with psychological ownership (Anger). 


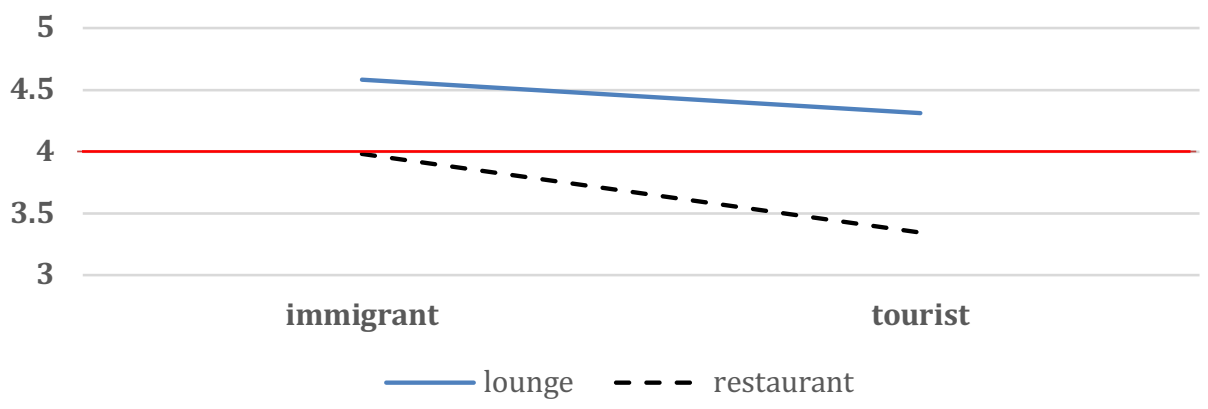

Figure 7. Interactions of the type of non-loyal customers with psychological ownership (Disappointment).

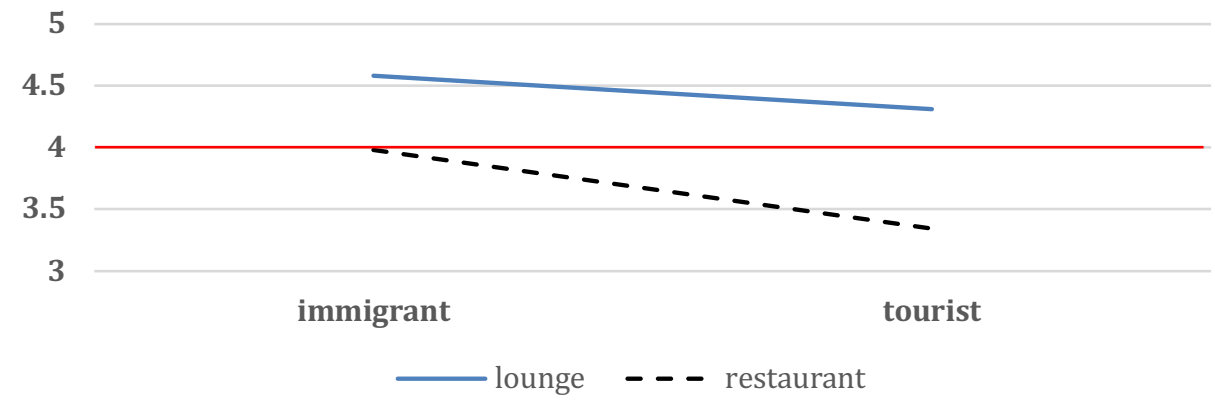

Figure 8. Interactions of the type of non-loyal customers with psychological ownership (Pride).

\subsection{Loyal Customers' Perceptions and the Link to Psychological Ownership}

In order to examine hypotheses 3 and 4, we analyzed the data using a two-way MANOVA test, with the types of non-loyal customers and psychological ownership as the independent variables and the loyal customers' perceptions (i.e., infringement, attitude, brand image, and switching intention) regarding the two types of non-loyal customers as the dependent variables. Tables 9 and 10 present the multivariate and univariate results of this test, including the effect of the types of non-loyal customers and psychological ownership on loyal customers' perceptions. The first result of the two-way MANOVA for infringement revealed significant differences between the types of nonloyal customers $\left(\mathrm{F}(1,1918)=25.680, \mathrm{p}<.001, \eta^{2}=.013\right)$ and the two different locations 
$\left(\mathrm{F}(1,1918)=6.342, \mathrm{p}<.001, \eta^{2}=.003\right)$. We also found a significant two-way interaction with psychological ownership $\left(\mathrm{F}(1,1918)=41.448, \mathrm{p}<.001, \eta^{2}=.021\right)$. The second MANOVA result for brand image indicated differences between the types of nonloyal customers $\left(\mathrm{F}(1,1918)=12.458, \mathrm{p}<.001, \eta^{2}=.006\right)$, while no differences were found between the two different backgrounds $\left(F(1,1918)=.550, p=.458, \eta^{2}=.000\right)$. Our analysis also revealed an insignificant two-way interaction with psychological ownership $(\mathrm{F}(1,1918)=.983, \mathrm{p}=.322, \eta 2=.001)$.

The third set of MANOVA results for attitude found significant main effects for types of non-loyal customers $\left(F(1,1918)=24.902, p<.001, \eta^{2}=.013\right)$ and psychological ownership $\left(F(1,1918)=4.025, \mathrm{p}<.05, \eta^{2}=.002\right)$. We also found a considerable two-way interaction with psychological ownership $(\mathrm{F}(1,1918)=19.824, \mathrm{p}$ $<.001, \eta 2=.010)$. Lastly, the two-way MANOVA results for the dimension of switching intention revealed that the main effect of types of non-loyal customers $(F(1,1918)=$ 8.444, $\left.\mathrm{p}<.01, \eta^{2}<.004\right)$ was noteworthy, while that of psychological ownership (F (1, $1918)=1.844, \mathrm{p}=.175, \eta 2=.001)$ was insignificant. However, a considerable two-way interaction with psychological ownership was observed $(\mathrm{F}(1,1918)=18.042, \mathrm{p}<.001$, $\left.\eta^{2}=.009\right)$ 
Table 9.

Results of Two-Way MANOVA for Loyal Customers'Emotions (Multivariate Results)

\begin{tabular}{lllll}
\hline Source & Wilk's & $\mathrm{F}$ & $\mathrm{p}$ & $\eta^{2}$ \\
\hline Intercept & .040 & 11379.083 & .000 & .960 \\
Types of non-loyal customers & .975 & 12.142 & .000 & .025 \\
$\begin{array}{l}\text { Immigrant vs. Tourist) } \\
\text { Psychological ownership }\end{array}$ & .995 & 2.165 & .071 & .005 \\
(Lounge vs. Restaurant) & & & & \\
Types of non-loyal customers $\times$ & .974 & 12.613 & .000 & .026 \\
Psychological ownership & & & & \\
\hline
\end{tabular}

Table 10.

Two-Way MANOVA Results for Dependent Variables

\begin{tabular}{lllllll}
\hline Source & $\begin{array}{l}\text { Sum of } \\
\text { Squares }\end{array}$ & df & $\begin{array}{l}\text { Mean } \\
\text { Square }\end{array}$ & F & $p$ & $\eta^{2}$ \\
\hline Loyal customers' infringement perceived by non-loyal customers & & & \\
Types of non-loyal customers & 65.983 & 1 & 65.983 & 25.680 & $\mathbf{. 0 0 0 * * *}$ & .013 \\
Psychological ownership & 16.295 & 1 & 16.295 & 6.345 & $\mathbf{. 0 1 2 *}$ & .003 \\
Types of non-loyal customers & 106.498 & 1 & 106.498 & 41.448 & $\mathbf{. 0 0 0 *}$ & .021 \\
$\times$ Psychological ownership & & & & & & \\
Error & 4917.855 & 1914 & 2.569 & & & \\
Total & 31734.556 & 1918 & & & & \\
Loyal customers' attitude toward non-loyal customers & & & & & \\
Types of non-loyal customers & 53.319 & 1 & 53.319 & 24.902 & $\mathbf{. 0 0 0 * * *}$ & .013 \\
Psychological ownership & 8.617 & 1 & 8.617 & 4.025 & $\mathbf{. 0 4 5 *}$ & .002 \\
Types of non-loyal customers & 42.446 & 1 & 42.446 & 19.824 & $\mathbf{. 0 0 0 * * *}$ & .010 \\
\hline
\end{tabular}


$\times$ Psychological ownership

$\begin{array}{llll}\text { Error } & 4098.250 & 1914 & 2.141\end{array}$

$\begin{array}{lll}\text { Total } & 38157.778 & 1918\end{array}$

Loyal customers' brand image perceived by non-loyal customers

$\begin{array}{lllllll}\text { Types of non-loyal customers } & 29.097 & 1 & 29.097 & 12.458 & \mathbf{. 0 0 0 * * *} & .006 \\ \text { Psychological ownership } & 1.284 & 1 & 1.284 & .550 & .458 & .000 \\ \text { Types of non-loyal customers } & 2.296 & 1 & 2.296 & .983 & .322 & .001 \\ \times \text { Psychological ownership } & & & & & & \\ \text { Error } & 4470.225 & 1914 & 2.2336 & & \\ \text { Total } & 39574.556 & 1918 & & & \end{array}$

Loyal customers' brand switching intention

$\begin{array}{lllllll}\text { Types of non-loyal customers } & 18.544 & 1 & 18.544 & 8.444 & \mathbf{. 0 0 4 * *} & .004 \\ \text { Psychological ownership } & 4.050 & 1 & 4.050 & 1.844 & .175 & .001 \\ \text { Types of non-loyal customers } & 39.621 & 1 & 39.621 & 18.042 & \mathbf{. 0 0 0 * * *} & .009 \\ \text { × Psychological ownership } & & & & & & \\ \text { Error } & 4203.206 & 1914 & 2.196 & & \\ \text { Total } & 38524.000 & 1918 & & & \end{array}$

Note. ${ }^{*} p<.05, * * * p<.001$ 


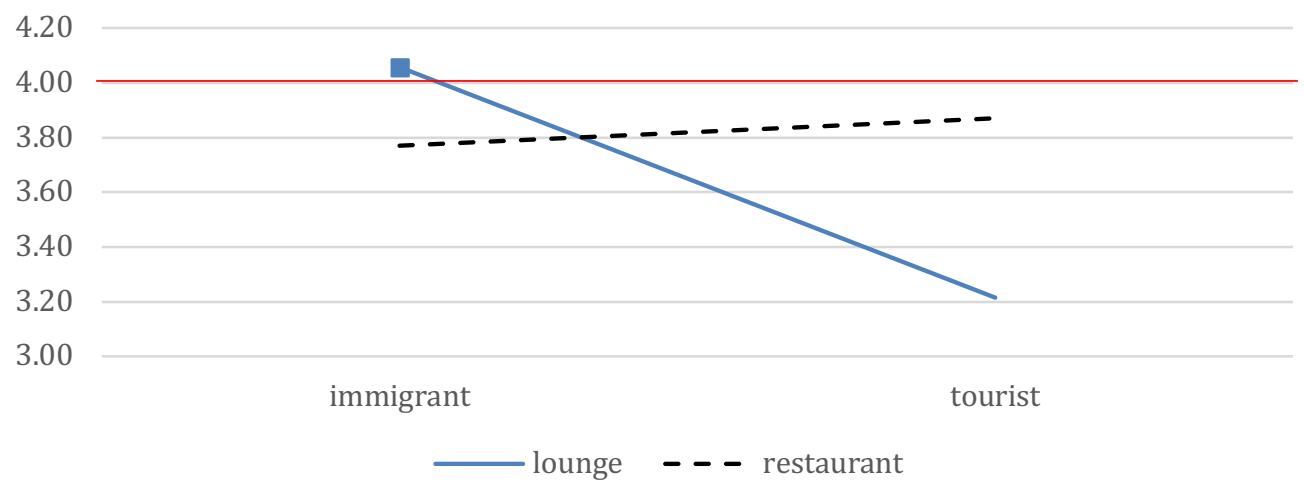

Figure 9. Interactions of the type of non-loyal customers with psychological ownership (Infringement)

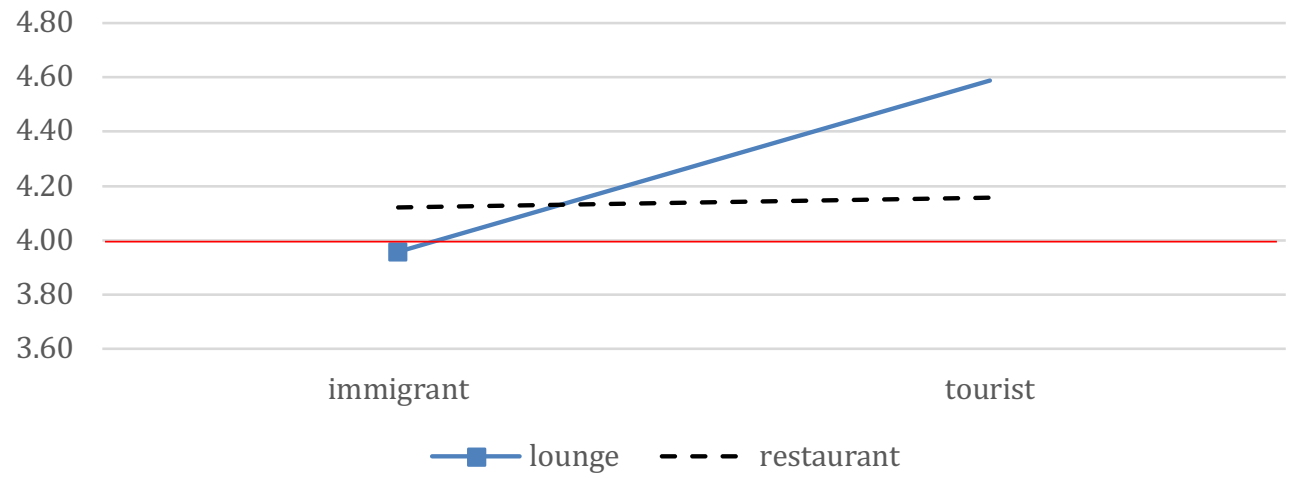

Figure 10. Interactions of the type of non-loyal customers with psychological ownership (Attitude)

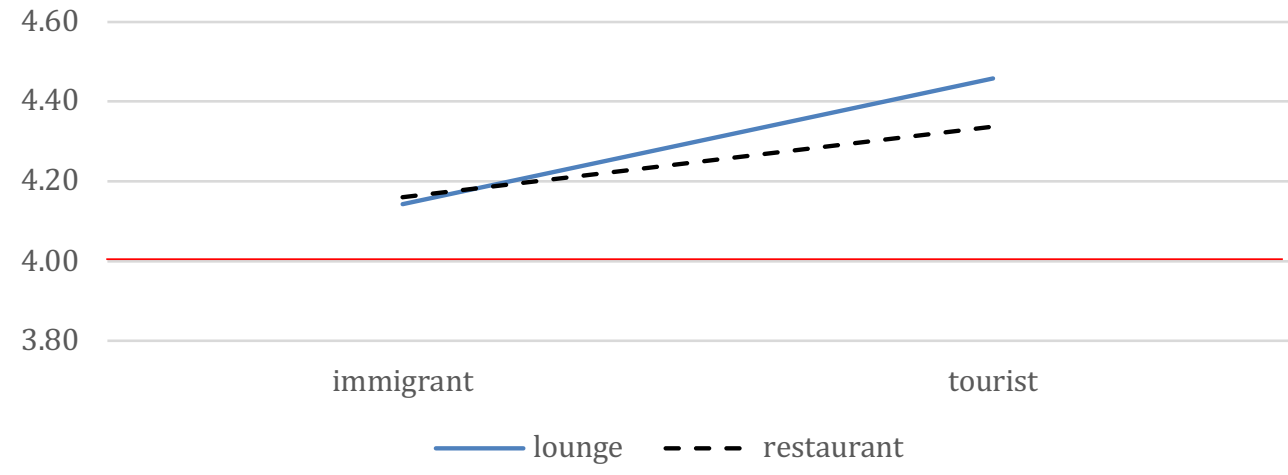

Figure 11. Interactions of the type of non-loyal customers with psychological ownership (Brand image) 


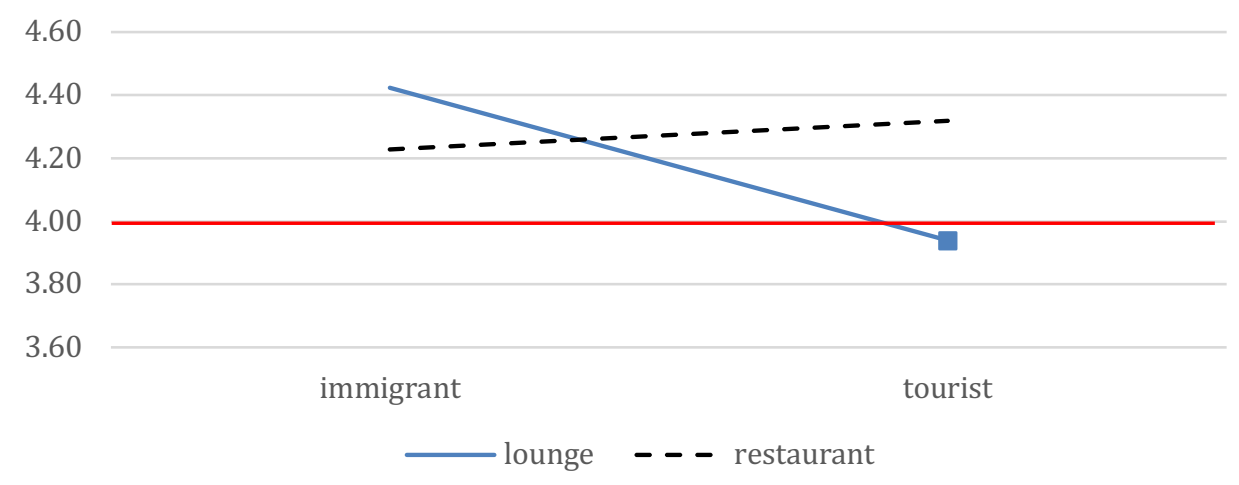

Figure 12. Interactions of the type of non-loyal customers with psychological ownership (Switching intention)

\subsection{The Relationship Among Loyal Customers' Perceptions of the Two Types of Non-Loyal Customers and Two Different Areas}

After comparing loyal customers' perceptions of the types of non-loyal customers, we examined the relationship among four variables (infringement, attitude, brand image, and switching intention). We found four different outcomes resulting from the perceptions of the two types of non-loyal customers (i.e., brand immigrants and brand tourists) and the two different research scenarios (i.e., the hotel lounge and the hotel restaurant) and the effect on psychological ownership.

Before examining the structural model, we calculated the Variance Inflation Factor (VIF) for the first-order factors of the study variables to assess the level of multicollinearity. As shown in Table 12, the VIF values were computed for three dimensions. First, if the observation of the $\mathrm{R}^{2}$ value is greater than .90 , this criterion indicates extreme multivariate collinearity. Second, the value of tolerance, which equals $1-\mathrm{R}^{2}$, indicates that the ratio of total standardized variance is unique. If the tolerance value is less than .10, this suggests extreme multivariate collinearity. The last value is 
VIF, which equals $1 /\left(1-\mathrm{R}^{2}\right)$. In terms of VIF, commonly recommended values are 10 (Hair et al., 1998), 5 (Kine, 2005), and 3.3 (Kock \& Lynn, 2012); meaning that a VIF equal to or greater than the threshold value would suggest the existence of collinearity among the variables (as known as multicollinearity). Of these researchers, Kock and Lynn (2012) found the lowest cut-off value of 3.3. In his study, he argues that the VIF value, which is greater than 3.3 , is considered to be an indication of pathological collinearity, and also an indication that the model may be contaminated by common method bias. In this study, all VIFs resulting from a full collinearity test presented lower than 3.3 (lounge: attitude: 1.110; brand image: 1.138; switching intention: 1.435; Restaurant: attitude:1.059; brand image: 1.170; switching intention: 1.575). We found no multicollinearity among the constructs; therefore, our study was free of common method bias.

Furthermore, to confirm the convergent validity, which is recommended by Fornell and Larcker (1981), we tested the measurement model and composite reliability (CR). In order to assess convergent validity, each construct's Average Variance Extracted (AVE; Hair et al., 2006) value was calculated. Internal consistency of all the constructs was measured by employing CR as suggested by Hoffmann and Birnbrich (2012). For this measure, the threshold criterion is 0.70 (Nunnally, 1978) and all the constructs included in this study exceeded the recommended level. Furthermore, we examined the factor loadings and the AVE to test the convergent validity of the constructs. The value of AVE should exceed 0.5 to obtain adequate convergent validity (Bagozzi \& Yi, 1988) and all the constructs included in this study exceeded the recommended level. In addition, communality was also measured to determine the quality of the structural model which should be greater than 0.5 . Finally, an inspection of correlations among constructs was 
conducted. From Tables 11 to Table 14, the tables show results of AVE, CR, R², Cronbach's alpha $(\alpha)$, the result of Variance Inflation Factor (VIF) and correlations among constructs.

Table 11.

Overall Model Fit of PLS Structural Model

\begin{tabular}{|c|c|c|c|c|c|c|c|c|}
\hline & \multicolumn{4}{|c|}{ Immigrant } & \multicolumn{4}{|c|}{ Tourist } \\
\hline & AVE & $\mathrm{CR}$ & $\mathrm{R}^{2}$ & $\alpha$ & AVE & $\mathrm{CR}$ & $\mathrm{R}^{2}$ & $\alpha$ \\
\hline Infringement & 0.820 & 0.932 & & 0.890 & 0.865 & 0.951 & & 0.922 \\
\hline Attitude & 0.868 & 0.952 & 0.099 & 0.924 & 0.846 & 0.943 & 0.056 & 0.910 \\
\hline Brand image & 0.843 & 0.942 & 0.121 & 0.907 & 0.863 & 0.950 & 0.145 & 0.920 \\
\hline $\begin{array}{l}\text { Switching } \\
\text { Intention }\end{array}$ & 0.617 & 0.817 & 0.403 & 0.650 & 0.593 & 0.788 & 0.375 & 0.585 \\
\hline
\end{tabular}

Table 12.

Result of Variance Inflation Factor (VIF)

\begin{tabular}{|c|c|c|c|c|c|c|}
\hline & \multicolumn{3}{|c|}{ Immigrant } & \multicolumn{3}{|c|}{ Tourist } \\
\hline & $\mathrm{R}^{2}$ & $1-\mathrm{R}^{2}$ & VIF & $\mathrm{R}^{2}$ & $1-\mathrm{R}^{2}$ & VIF \\
\hline Attitude & 0.099 & .901 & 1.110 & 0.056 & .944 & 1.059 \\
\hline Brand image & 0.121 & .879 & 1.138 & 0.145 & .855 & 1.170 \\
\hline Switching intention & 0.403 & .697 & 1.435 & 0.375 & .635 & 1.575 \\
\hline
\end{tabular}


Table 13.

Latent variable correlation (Brand immigrant)

\begin{tabular}{|c|c|c|c|c|c|c|c|}
\hline & Angry & Proud & Disappoint & Infringement & $\begin{array}{l}\text { Brand } \\
\text { image }\end{array}$ & Attitude & $\begin{array}{l}\text { Switching } \\
\text { intention }\end{array}$ \\
\hline Angry & 1 & & & & & & \\
\hline Proud & -.047 & 1 & & & & & \\
\hline Disappointed & $.784^{* *}$ & $-.086^{* *}$ & 1 & & & & \\
\hline Infringement & $.517^{* *}$ & .015 & $.500^{* *}$ & 1 & & & \\
\hline Brand image & $.122^{* *}$ & .048 & $.079^{*}$ & $.111^{* *}$ & 1 & & \\
\hline Attitude & $-.098^{* *}$ & .029 & $-.125^{* *}$ & $-.233^{* *}$ & $.328^{* *}$ & 1 & \\
\hline $\begin{array}{l}\text { Switching } \\
\text { intention }\end{array}$ & $.341^{* *}$ & .009 & $.314^{* *}$ & $.605^{* *}$ & $.074^{*}$ & $-.140^{* *}$ & 1 \\
\hline
\end{tabular}

Table 14.

Latent variable correlation (Brand tourist)

\begin{tabular}{|c|c|c|c|c|c|c|c|}
\hline & Angry & Proud & Disappoint & Infringement & $\begin{array}{l}\text { Brand } \\
\text { image }\end{array}$ & Attitude & $\begin{array}{l}\text { Switching } \\
\text { intention }\end{array}$ \\
\hline Angry & 1. & & & & & & \\
\hline Proud & $-.121^{* *}$ & 1 & & & & & \\
\hline Disappointed & $.751^{* *}$ & $-.168^{* *}$ & 1 & & & & \\
\hline Infringement & $.473^{* *}$ & .016 & $.452^{* *}$ & 1 & & & \\
\hline Brand image & $.091^{* *}$ & .058 & $.112^{* *}$ & $.069^{*}$ & 1 & & \\
\hline Attitude & $-.114^{* *}$ & $.077^{*}$ & $-.097^{* *}$ & $-.311^{* *}$ & $.302^{* *}$ & 1 & \\
\hline $\begin{array}{l}\text { Switching } \\
\text { intention }\end{array}$ & $.342^{* *}$ & .030 & $.316^{* *}$ & $.615^{* *}$ & -.011 & $-.204^{* *}$ & 1 \\
\hline
\end{tabular}

Note. ${ }^{*} p<.05,{ }^{* *} p<.01$ 
In this study, we examined loyal customers' perceptions of the two types of nonloyal customers (brand immigrants and brand tourists). We found that when non-loyal customers were perceived as brand immigrants, in the model, hypothesis 5a, the association between infringement and attitude was supported by the path coefficient (beta $=-.314, \mathrm{t}=7.777, \mathrm{p}<0.001$ ), indicating that infringement had a significant impact on attitude. Second, for hypothesis $5 \mathrm{~b}$, the association between the infringement and brand image was also supported by the estimate (beta $=.180, \mathrm{t}=5.279, \mathrm{p}<0.001)$. This result showed that infringement is a significant antecedent of brand image.

For hypothesis $5 \mathrm{c}$, the result revealed that infringement exerted a significant influence on switching intention, supporting it by a significant margin (beta $=.586, \mathrm{t}=$ $18.959, \mathrm{p}<0.001$ ). Fourth, hypothesis $5 \mathrm{~d}$ was supported by a path coefficient (beta $=.359, \mathrm{t}=10.752, \mathrm{p}<0.001)$, indicating that attitude was a significant predictor of brand image. Hypothesis 5e, anticipating the association between attitude and switching intention, was not supported (beta $=-.093, \mathrm{t}=2.420, \mathrm{p}>.001$ ). Finally, for hypothesis 1f, the association between the brand image and switching intention was supported by the estimation (beta $=-.142, \mathrm{t}=3.465, \mathrm{p}>.001)$.

In the restaurant scenario, to test $\mathrm{H} 6 \mathrm{a}$, the relationship between infringement and attitude was supported by the path coefficient (beta $=-.237, \mathrm{t}=6.055, \mathrm{p}<0.001$ ), indicating that the former had a significant impact on the latter. For hypothesis $6 \mathrm{~b}$, the association between the infringement and brand image was also supported by the estimate (beta $=.199, \mathrm{t}=5.904, \mathrm{p}<.001)$. This result showed that infringement is a significant antecedent of brand image. 
For hypothesis $6 \mathrm{c}$, the result revealed that infringement exerted a significant influence on switching intention, thus supporting this hypothesis by a significant margin (beta $=.593, \mathrm{t}=18.889, \mathrm{p}<.001)$. Fourth, hypothesis $6 \mathrm{~d}$ was supported by a path coefficient (beta $=.375, \mathrm{t}=11.164, \mathrm{p}<.001)$, indicating that attitude is a significant predictor of brand image. Unlike the results regarding perception of the lounge, in the restaurant, H6e, hypothesizing an association between attitude and switching intention, was not supported (beta $=-.070, t=1.387$ ). Finally, for hypothesis $1 \mathrm{f}$, the association between the brand image and switching intention was not supported by the estimation (beta $=-.045, \mathrm{t}=1.004)$.

Table 15.

Loyal Customers' Different Perceptions of Brand Immigrants and Brand Tourists

\begin{tabular}{|c|c|c|c|c|c|c|c|c|}
\hline & \multicolumn{4}{|c|}{ Immigrants } & \multicolumn{4}{|c|}{ Tourists } \\
\hline & beta & S.D & S.E & t-value & beta & S.D & S.E & t-value \\
\hline INF $\rightarrow$ ATT & -0.314 & 0.040 & 0.040 & $7.777 * * *$ & -0.237 & 0.039 & 0.039 & $6.055 * * *$ \\
\hline $\mathrm{INF} \rightarrow \mathrm{BI}$ & 0.180 & 0.034 & 0.034 & $5.279 * * *$ & 0.199 & 0.034 & 0.034 & $5.904 * * *$ \\
\hline INF $\rightarrow$ SI & 0.586 & 0.031 & 0.031 & $18.959 * * *$ & 0.593 & 0.031 & 0.031 & $18.889 * * *$ \\
\hline $\mathrm{ATT} \rightarrow \mathrm{BI}$ & 0.359 & 0.033 & 0.033 & $10.752 * * *$ & 0.375 & 0.034 & 0.034 & $11.164 * * *$ \\
\hline $\mathbf{A T T} \rightarrow \mathrm{SI}$ & -0.093 & 0.039 & 0.039 & $2.420 *$ & -0.070 & 0.050 & 0.050 & 1.387 \\
\hline $\mathrm{BI} \rightarrow \mathrm{SI}$ & -0.142 & 0.041 & 0.041 & $3.465 * * *$ & -0.045 & 0.044 & 0.044 & 1.004 \\
\hline
\end{tabular}

Note. INF-Infringement, ATT-Attitude, BI-Brand image, SI-Switching intention Note. ${ }^{*} p<.05,{ }^{* * *} p<.001$ 


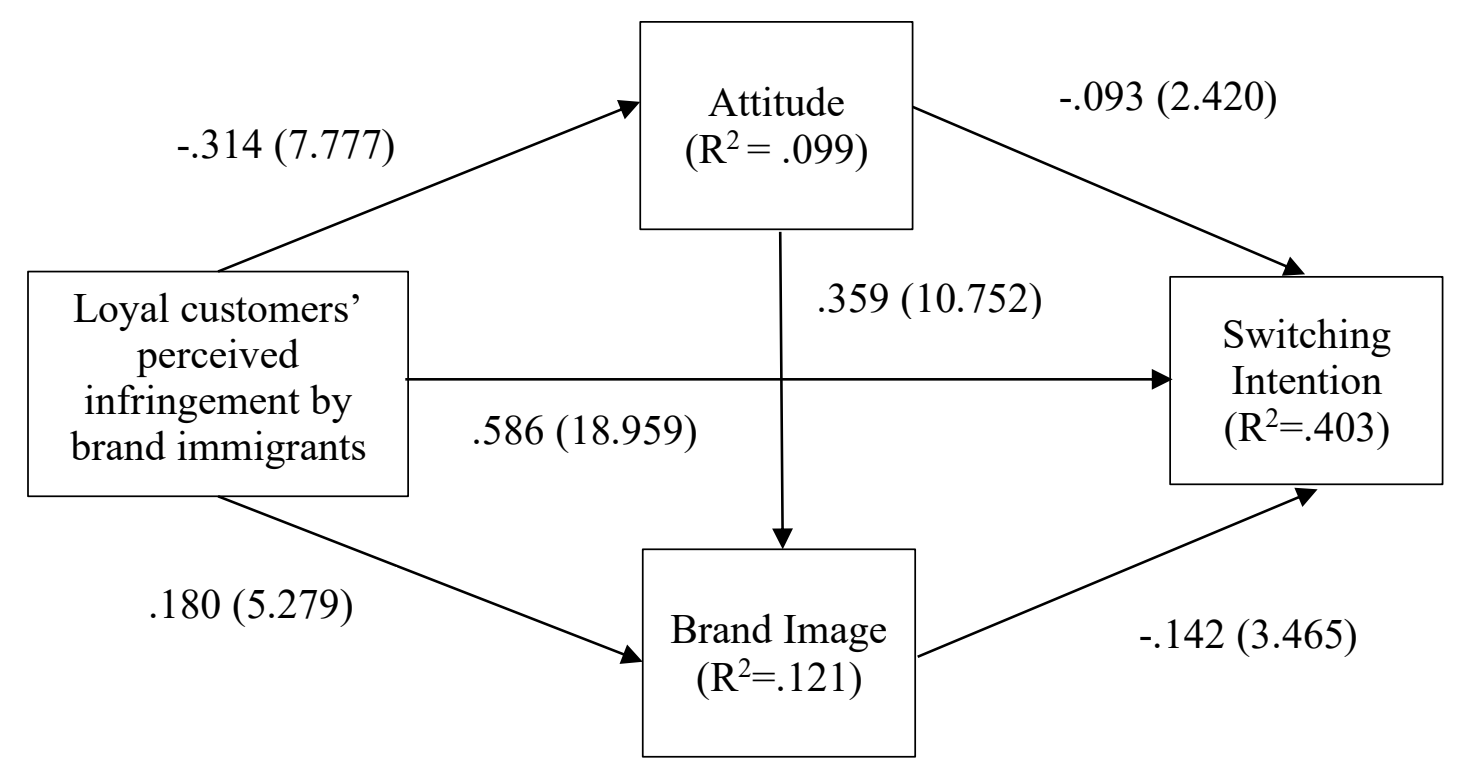

Figure 13. Structural model of loyal customers' perception on brand immigrants.

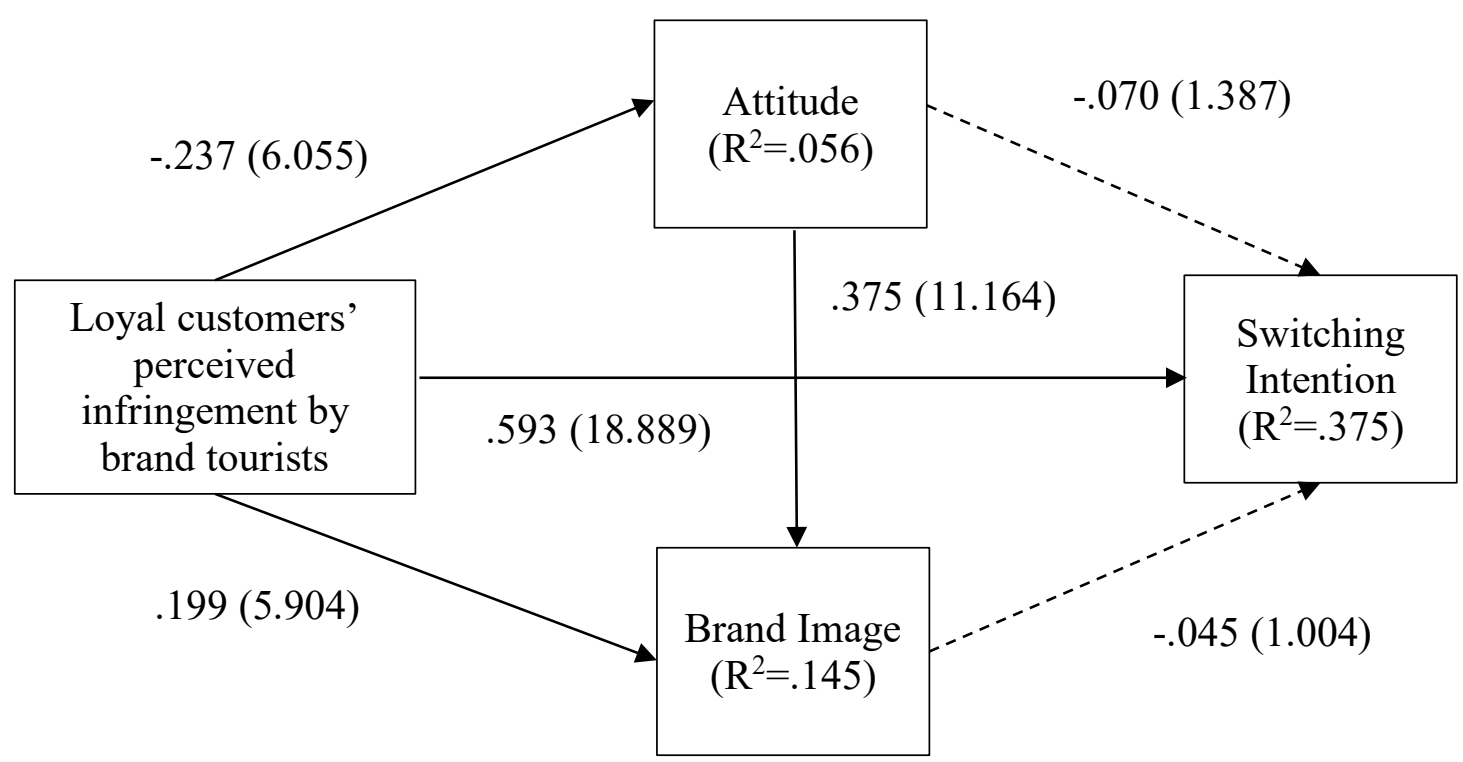

Figure 14. Structural model of loyal customers' perception on brand tourists. 
In addition to the results associated with how non-loyal customers are viewed (brand immigrants and brand tourists), we also examined how non-loyal customers are viewed differently in different places (lounge and restaurant) where one is associated with a high level of psychological ownership and the other is not related to a high level of psychological ownership. When we examined perceptions of brand immigrants in the lounge, we found that the relationship between infringement and attitude was supported by the path coefficient (beta $=-.308, \mathrm{t}=4.791, \mathrm{p}<0.001$ ), indicating that the former had a significant impact on the latter. Second, the relationship between infringement and brand image was also supported by the estimate (beta $=.194, \mathrm{t}=3.903, \mathrm{p}<0.001)$. This result showed that infringement was a significant antecedent of brand image.

Next, our results revealed that infringement exerted a significant influence on switching intention as indicated by a significant estimate (beta $=.573, \mathrm{t}=12.761, \mathrm{p}$ $<.001$ ). The next relationship was supported by a path coefficient (beta $=.341, \mathrm{t}=6.971$, $\mathrm{p}<0.001$ ), indicating that attitude was a significant predictor of brand image. Also, the association between attitude and switching intention was found to be significant by the estimation (beta $=-.085, \mathrm{t}=1.305)$. Finally, the relationship between brand image and switching intention was also supported by the estimation (beta $=-.146(t=2.407, p$ $>$.05). Then, we examined the perceptions of brand immigrants in the restaurant. The first relationship between infringement and attitude was supported by the path coefficient (beta $=-.312, \mathrm{t}=5.323, \mathrm{p}<0.001$ ), indicating that infringement had a significant impact on attitude. The relationship between infringement and brand image was also supported by the estimation (beta $=.166, \mathrm{t}=3.908, \mathrm{p}<0.01$ ). This result showed that infringement was a significant antecedent of brand image. 
The next result indicates that infringement exerted a significant influence on switching intention, indicated by an estimation (beta $=.599, \mathrm{t}=12.755, \mathrm{p}<.001)$. A path coefficient (beta $=.382, \mathrm{t}=7.289, \mathrm{p}<0.001$ ), showing the result of the relationship between attitude and brand image, revealed that the former was a significant predictor of the latter. However, the association between attitude and switching intention was weak, as indicated by an estimation (beta $=-.093, \mathrm{t}=1.625)$. However, the relationship between brand image and switching intention was also supported by the estimation (beta $=-.141, \mathrm{t}=1.988, \mathrm{p}>.05)$.

Table 16.

Loyal customers' Different Perceptions Toward Brand Immigrants' Behavior in Different Areas

\begin{tabular}{ccccccccccccc}
\hline & \multicolumn{3}{c}{ Immigrants in Lounge } & \multicolumn{3}{c}{ Immigrants in Restaurant } & \multicolumn{3}{c}{ Group Difference } \\
\cline { 2 - 11 } & beta & SD & SE & t-value & beta & SD & SE & t-value & |diff| & t-value & p-value \\
\hline INF $\rightarrow$ ATT & -0.308 & 0.064 & 0.064 & $\mathbf{4 . 7 9 1 * * *}$ & -0.312 & 0.059 & 0.059 & $\mathbf{5 . 3 2 3} * * *$ & .004 & .046 & .963 \\
INF $\rightarrow$ BI & 0.194 & 0.050 & 0.050 & $\mathbf{3 . 9 0 3 * * *}$ & 0.166 & 0.054 & 0.054 & $\mathbf{3 . 0 9 8 * *}$ & .028 & .381 & .703 \\
INF $\rightarrow$ SI & 0.573 & 0.045 & 0.045 & $\mathbf{1 2 . 7 6 1 * * *}$ & 0.599 & 0.047 & 0.047 & $\mathbf{1 2 . 7 5 5 * * *}$ & -.026 & .400 & .689 \\
ATT $\rightarrow$ BI & 0.341 & 0.049 & 0.049 & $\mathbf{6 . 9 7 1 * * *}$ & 0.382 & 0.052 & 0.052 & $\mathbf{7 . 2 8 9} * * *$ & -.041 & .574 & .566 \\
ATT $\rightarrow$ SI & -0.085 & 0.065 & 0.065 & 1.305 & -0.093 & 0.057 & 0.057 & 1.625 & .008 & .093 & .926 \\
BI $\rightarrow$ SI & -0.146 & 0.060 & 0.060 & $\mathbf{2 . 4 0 7 *}$ & -0.141 & 0.071 & 0.071 & $\mathbf{1 . 9 8 8 *}$ & -.005 & .054 & .957 \\
\hline
\end{tabular}

Note. INF-Infringement, ATT-Attitude, BI-Brand image, SI-Switching intention Note. ${ }^{*} p<.05, * * * p<.001$

Using multi-group analysis (MGA), hypothesis 7 is tested to compare the relationships between the two groups. It is explored how loyal customers viewed brand immigrants differently in different locations. The result of these relationships were statistically significant. However, unfortunately, unlike the results of the comparison 
study using the MANOVA test, this study did not reveal a significant difference in the relationships among the variables.

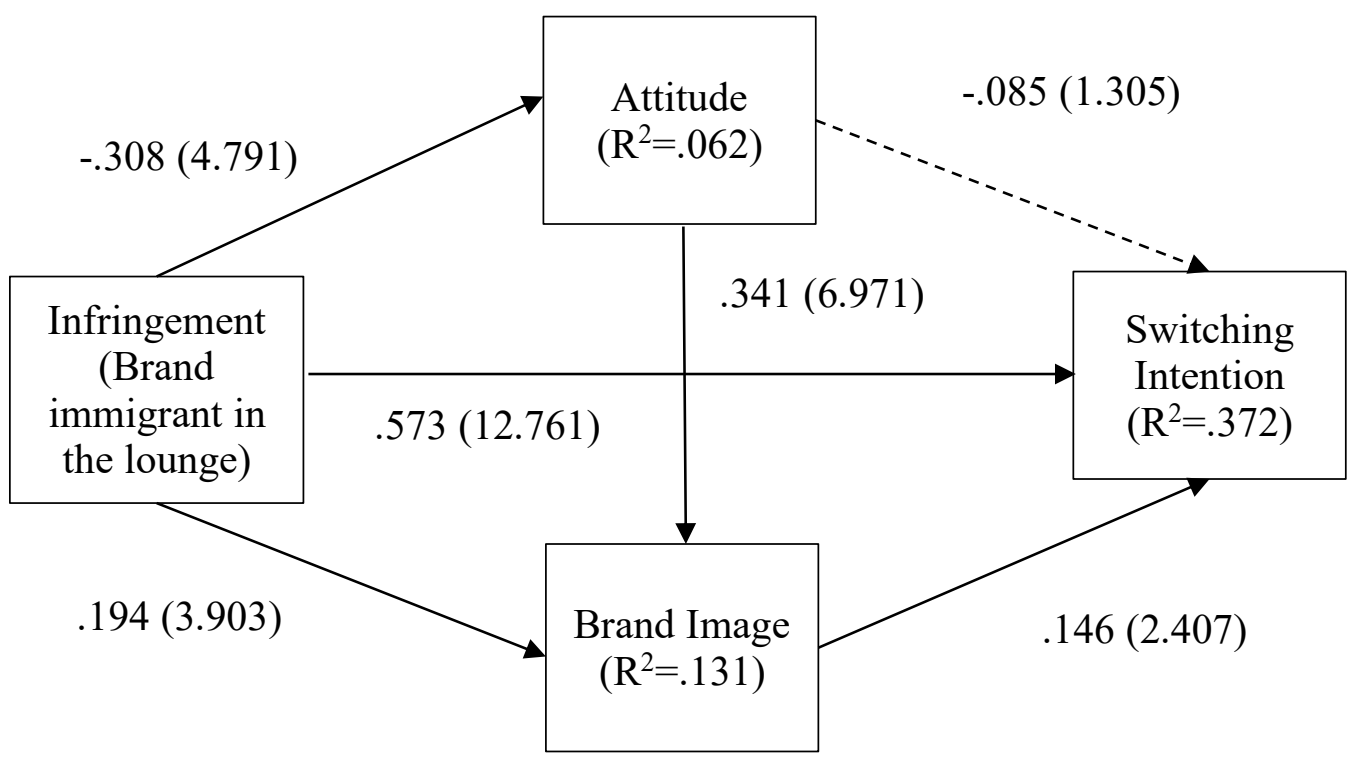

Figure 15. Structural model of loyal customers' perception on brand immigrants in the lounge.

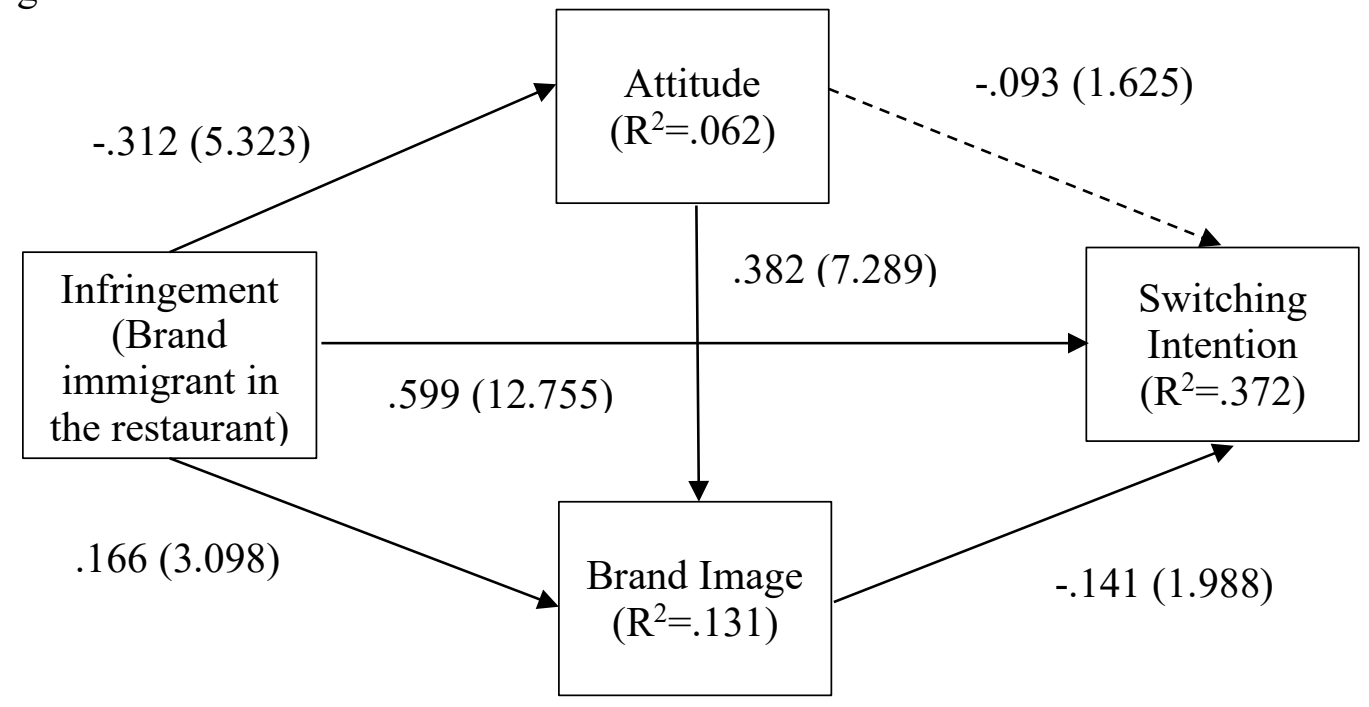

Figure 16. Structural model of loyal customers' perception on brand immigrant in the restaurant. 
Furthermore, the results also indicated loyal customers' perceptions of brand tourists in the two places. Before this hypothesis is tested and the differences were compared, the study examined the relationships among the variables. The first association between infringement and attitude was supported by the path coefficient (beta $=-.181, \mathrm{t}$ $=3.074, \mathrm{p}<.01)$, indicating that the former had a significant impact on the latter. The relationship between infringement and brand image was also supported by the significant estimation (beta $=.204, \mathrm{t}=3.978, \mathrm{p}<.001)$. This result revealed that infringement was a significant antecedent of brand image. Then, infringement had a significant influence on switching intention, indicated by a significant margin (beta $=.593, \mathrm{t}=12.910, \mathrm{p}<.001$ ). The next relationship was supported by a path coefficient (beta $=.384, \mathrm{t}=7.354, \mathrm{p}<$ 0.001), indicating that attitude was a significant predictor of brand image. However, the relationships between attitude and switching intention (beta $=-.036, \mathrm{t}=.466)$ and between brand image and switching intention (beta $=-.006, \mathrm{t}=.086$ ) were not supported by the path coefficient.

The relationship between infringement and attitude was supported by the path coefficient (beta $=-.249, \mathrm{t}=4.012, \mathrm{p}<.001)$, indicating that infringement had a significant impact on attitude. The next relationship between infringement and brand image was also supported by a significant margin $($ beta $=.196, \mathrm{t}=3.882, \mathrm{p}<.001)$, which showed that infringement was a significant antecedent of brand image. It is also found that infringement had a significant influence on switching intention by a significant margin (beta $=.579, \mathrm{t}=12.610, \mathrm{p}<.001)$. This indicates that attitude was a significant predictor of brand image, which was indicated by a path coefficient $($ beta $=.357, \mathrm{t}=$ $7.253, \mathrm{p}<0.001)$. Finally, the relationships between attitude and switching intention 
(beta $=-.093, \mathrm{t}=.1 .239)$ and between brand image and switching intention (beta $=$

$-.083, \mathrm{t}=.1 .320$ were not supported by the path coefficients.

Table 17.

Loyal Customers' Different Perceptions Toward Brand Tourists'Behavior in Different Areas

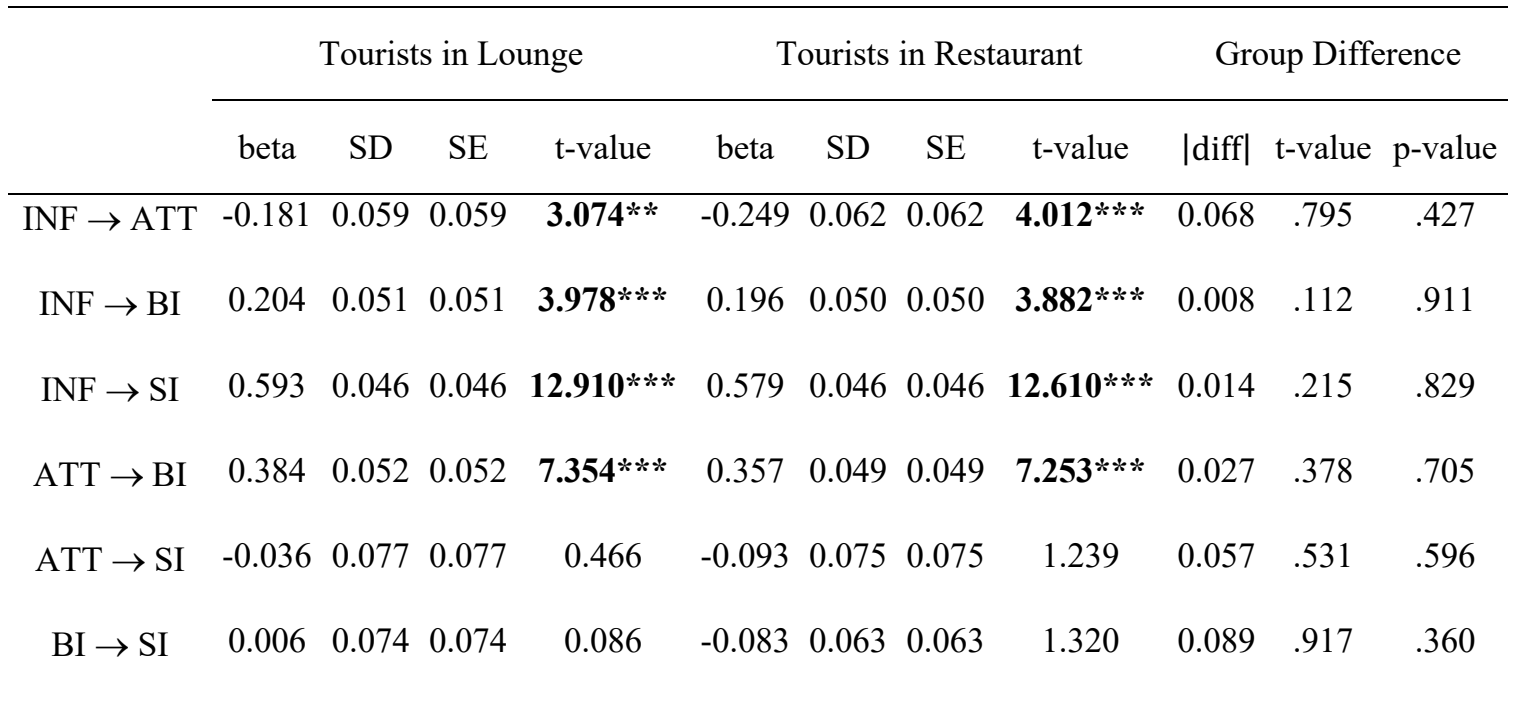

Note. INF-Infringement, ATT-Attitude, BI-Brand image, SI-Switching intention Note. $* * p<.01, * * * p<.001$

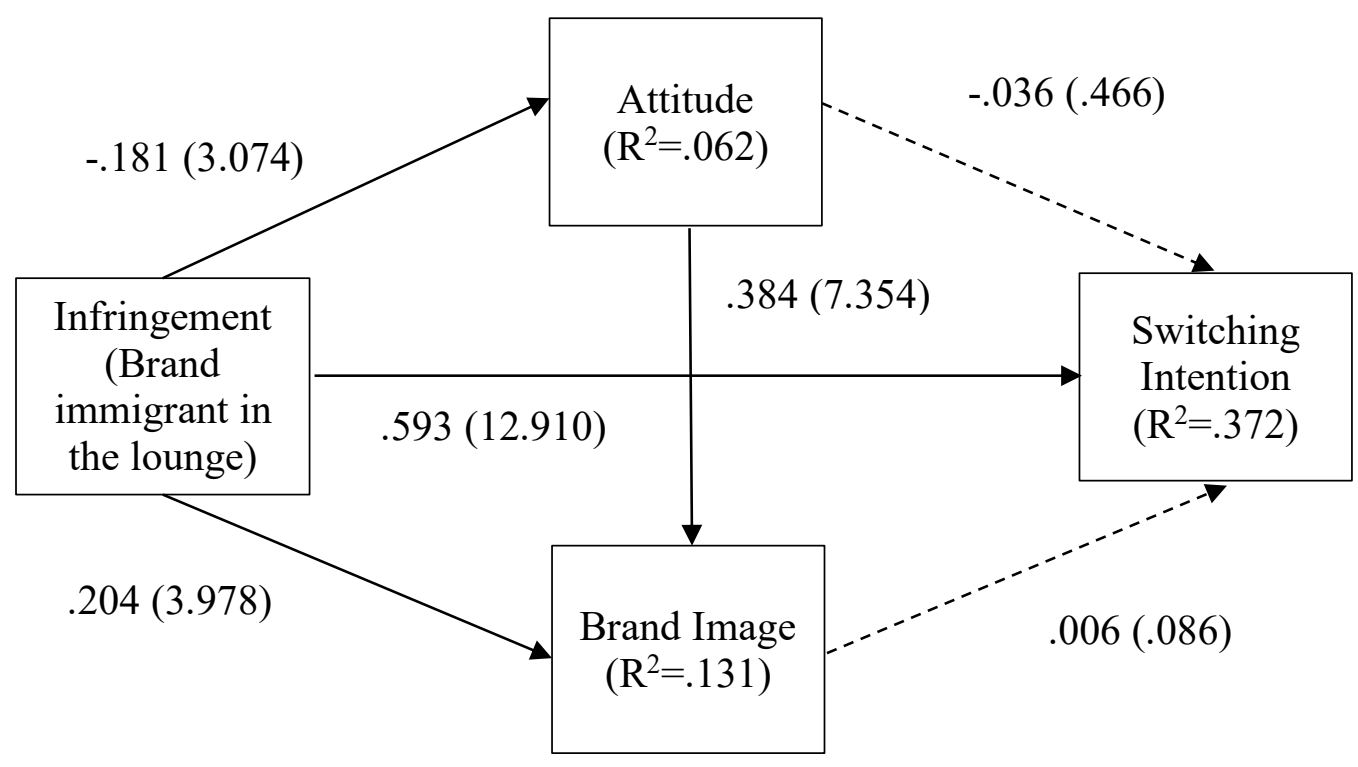

Figure 17. Structural model of loyal customers' perception on brand tourists in the lounge. 


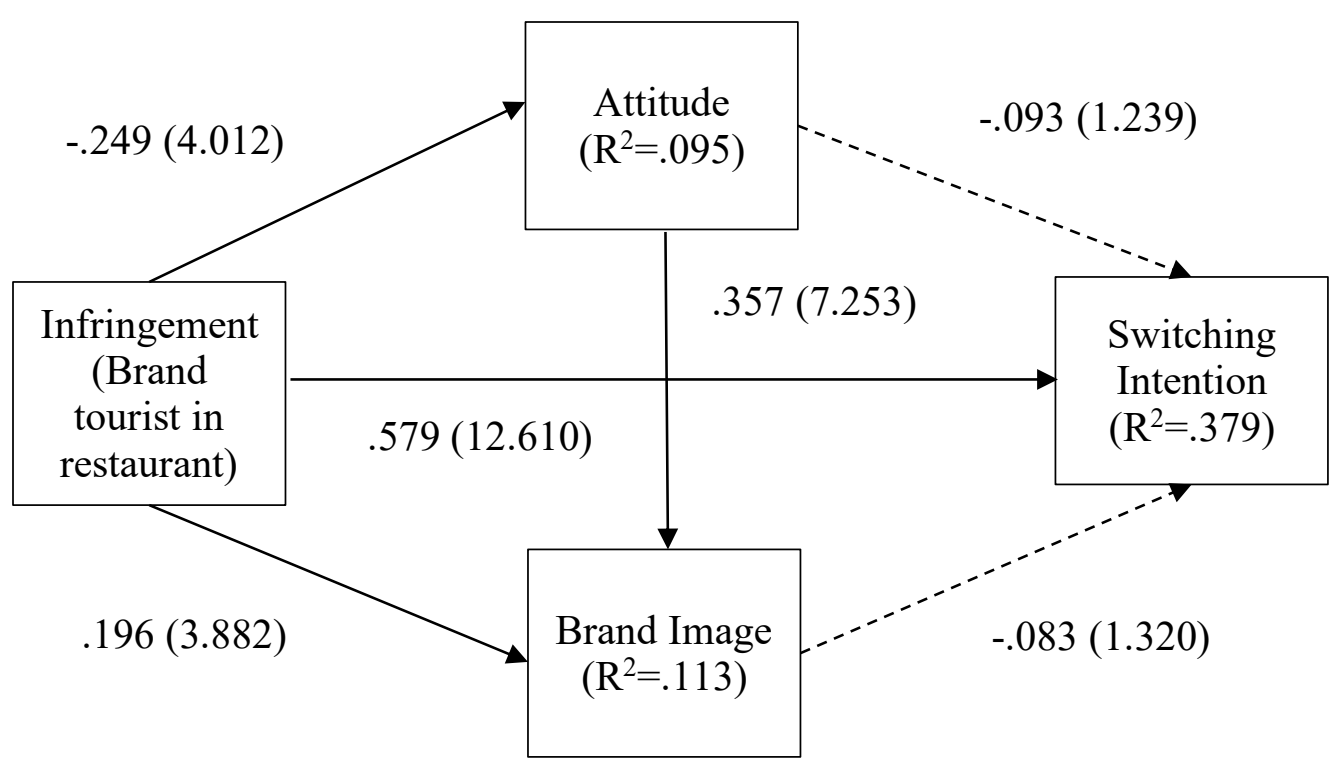

Figure 18. Structural model of loyal customers' perception on brand tourists in the restaurant.

Using multi-group analysis (MGA), hypothesis 8 was tested to compare the perceptions by loyal customers of brand tourists who used the lounge and the restaurant. The result identified these relationships as statistically significant. However, unfortunately, unlike the result of the comparison study conducted using the MANOVA test, the result of the PLS-SEM test was not able to find significant differences between non-loyal customers in the lounge and those in the restaurant.

Lastly, after verifying the hypotheses, to test the predictive power of the research model using PLS analysis, many scholars have turned to the explained variance $\left(\mathrm{R}^{2}\right)$ of the endogenous constructs (Chin, 2010) to determine the level of variance in the construct which is explained by the model. As shown in Table 10 , the $\mathrm{R}^{2}$ values for brand immigrants indicate .099 (attitude), .121 (brand image), and .403 (switching intention) and $\mathrm{R}^{2}$ values for brand tourists show .056 (attitude), .145 (brand image), and .375 (switching intention). The outcomes indicate that the model has high predictive value and 
is capable of explaining endogenous constructs (Cohen, 1988). The predictive sample reuse technique has also been shown to have a high level of predictive relevance (Chin, 2010). This technique, developed by Geisser (1975) and Stone (1974), is also known as the Stone-Geisser's $\mathrm{Q}^{2}$. In Smart PLS utilizing the blindfolding technique, when the $\mathrm{Q}^{2}$ values of the endogenous constructs are calculated, it is found all $\mathrm{Q}^{2}$ values were greater than ' 0 ' (ranging from 0.211 to 0.513 ), which is indicative of the endogenous constructs' high rate of predictive relevance.

\subsection{Summary}

In this chapter, two different streams of investigation are utilized. First, the study examined the loyal customers' perceptions (i.e., emotion, infringement, attitude, brand image and switching intention) of non-loyal customers as brand immigrants or brand tourists. Loyal customers felt various emotions, such as anger, disappointment, and pride, depending on how they viewed non-loyal customers. In addition, the level of psychological ownership (i.e., restaurant and lounge) played a moderating role between the two different types of non-loyal customers and loyal customers' perceptions. To compare the groups with the variables, MANOVA tests were conducted.

Second, the study also investigated the relationship among loyal customers' perceptions of non-loyal customers including infringement, attitude, brand image, and switching intentions by employing the structural equation model and attempted to compare these relationships depending on the different locations in the hotel, which are associated with differing levels of psychological ownership. The results indicated similar outcomes between perceptions of brand immigrants and brand tourists; however, the relationships among attitude, brand image and switching intention indicated different 
results. On the other hand, in terms of the results of the multigroup analysis between the lounge and the restaurant, no significant difference was found.

The summarized results are shown Table 18 and further discussion of the research findings will be presented in Chapter 5 .

Table 18.

Hypothesis Results

Hypothesis Result

H1: Loyal customers' emotions (i.e., pride, disappointment, and anger), infringement, attitude, brand image, and switching intention perceived by or toward non-loyal customers will be different depending on whether or not they are perceived as brand tourists or immigrants.

H1a: Loyal customers will perceive higher levels of pride toward brand tourists than brand immigrants.

Supported

H1b: Loyal customers will perceive higher levels of disappointment toward brand immigrants than brand tourists.

H1c: Loyal customers will perceive higher levels of anger toward brand immigrants than brand tourists.

Supported

H1d: Loyal customers will perceive a higher rate of

Supported infringement toward brand immigrants than brand tourists.

H1e: Loyal customers will have more positive attitudes toward brand tourists than brand immigrants.

Supported

H1f: Loyal customers' perceived brand image will be different depending on whether non-loyal customers are perceived as brand tourists or brand immigrants.

H1g: Loyal customers will perceive higher switching intention due to the presence of brand immigrants rather than brand tourists.

H2: Psychological ownership will have a significant moderating effect on the relationship between the types of non-loyal customers and loyal customers' perceived emotions (i.e., pride, 
disappointment, and anger), infringement, attitude, brand image, and switching intention.

H2a: Psychological ownership will have a significant moderating effect on the relationship between the types of non-loyal customers and loyal customers' pride

H2b: Psychological ownership will have a significant moderating effect on the relationship between the types of non-loyal customers and loyal customers' disappointment

H2c: Psychological ownership will have a significant moderating effect on the relationship between the types of non-loyal customers and loyal customers' anger

H2d: Psychological ownership will have a significant moderating effect on the relationship between the types of non-loyal customers and loyal customers' perceived infringement

H2e: Psychological ownership will have a significant moderating effect on the relationship between the types of non-loyal customers and loyal customers' attitudes

H2f: Psychological ownership will have a significant moderating effect on the relationship between the types of non-loyal customers and loyal customers' brand image

H2g: Psychological ownership will have a significant moderating effect on the relationship between the types of non-loyal customers and loyal customers' switching intention

Supported

Supported

Supported

Supported

Supported

Not supported

Supported

H3: When loyal customers view non-loyal customers as brand immigrants, their perceptions (i.e., infringement, attitude, brand image, switching intention) toward them will be impacted

H3a: When loyal customers view non-loyal customers as brand immigrants, their infringement will have a negative impact on attitude.

H3b: When loyal customers view non-loyal customers as brand immigrants, their infringement will have a negative impact on brand image.

H3c: When loyal customers view non-loyal customers as brand immigrants, their infringement will have a positive Supported impact on switching intention.

Supported

Supported 
H3d: When loyal customers view non-loyal customers as

Supported

brand immigrants, their attitude will have a positive impact on

brand image.

H3e: When loyal customers view non-loyal customers as

Not supported

brand immigrants, their attitude will have a positive impact on

switching intention.

H3f: When loyal customers view non-loyal customers as

brand immigrants, their brand image will have a negative

impact on switching intention.

H4: When loyal customers view non-loyal customers as brand tourists, the relationship among loyal customers' perceptions (i.e., infringement, attitude, brand image, switching intention) toward non-loyal customers will be impacted.

H4a: When loyal customers view non-loyal customers as brand tourists, their infringement will have a positive impact on attitude.

H4b: When loyal customers view non-loyal customers as brand tourists, their infringement will have a negative impact on brand image.

H4c: When loyal customers view non-loyal customers as brand tourists, their infringement will have a positive impact on switching intention.

H4d: When loyal customers view non-loyal customers as brand tourists, their attitude will have a positive impact on brand image.

H4e: When loyal customers view non-loyal customers as brand tourists, their attitude will have a positive impact on switching intention.

H4f: When loyal customers view non-loyal customers as brand tourists, their brand image will have a negative impact on switching intention

H5: When non-loyal customers are viewed as brand immigrants, the relationship among loyal customers' perceptions (i.e., infringement, attitude, brand image, switching intention) toward non-loyal customers will be impacted differently depending on the location (i.e., lounge vs. restaurant).

Supported

Supported

Supported

Supported

Supported

Supported

Not supported 
H6: When loyal customers view non-loyal customers as brand tourists, the relationship among loyal customers' perceptions (i.e., Not supported infringement, attitude, brand image, switching intention) will be different depending on the location (i.e., lounge vs. restaurant). 


\section{CHAPTER 5}

\section{CONCLUSION}

This chapter presents a discussion of the results and findings, the implications of the study for the hospitality industry and for academia, some suggestions for future research, and the limitations of the study.

\subsection{Summary and Discussion}

In the hotel industry, the goal of the service providers is to offer better service to the customers in order to establish and maintain a long-term relationship with them. This is particularly true for those in the luxury hotel business. Therefore, the most widely used strategy to achieve this objective is customer relationship marketing, which is used to maintain the customer base, and to offer financial and social benefits and structural ties. For example, many hotel executives provide personalized service to their loyal customers such as exclusive access to the membership lounge. However, when these executives started to open up the exclusive area, where previously only loyal customers could have access, to almost all guests via diverse promotion deals, many loyal customers began to complain about crowding and hesitated to use the membership lounge.

Under these circumstances, this study has attempted to answer the question of how hotel executives provide the best service to every customer without losing their loyal customers. The first objective of this study was to compare the loyal customers' perceptions (i.e., emotions such as anger, disappointment, and pride, infringement, attitude, brand image, and switching intention) in response to non-loyal customers. The second objective was to examine the relations among their perceptions (infringement, 
attitude, brand image, and switching intention). The final objective was to compare the relationships among the variables in response to the non-loyal customers being given access to the lounge and restaurant.

First, the results of the MANOVA test indicate that loyal customers experience significantly different emotions depending on how they perceive non-loyal customers. Specifically, when non-loyal customers are viewed as brand immigrants, loyal customers are more likely to feel negative emotions including anger and disappointment; however, when loyal customers view them as brand tourists, they tend to feel positive emotions such as pride. Loyal customers felt higher levels of anger and disappointment toward non-loyal customers in the lounge than the restaurant, while they felt higher levels of pride toward brand tourists in both areas, the restaurant and the lounge. In addition, the outcome also shows that the differences between two types of non-loyal customers and between two different areas are shown to be greater in negative emotions such as anger and disappointment than in positive emotions such as pride. This outcome implies that wealthy people are likely to show their negative emotion more clearly. From this result, it can be stated that loyal customers' behaviors and perceptions indicate a snob effect and that feelings regarding brand immigrants show the Veblen effect.

Second, as a result of the interaction effect of the sense of psychological ownership in the lounge, loyal customers' distinct views on brand immigrants and brand tourists were statistically significant. However, in the restaurant, no significant differences between loyal customers' perceptions of the two types of non-loyal customers could be found. The outcomes found that loyal customers viewed brand tourists in a much more positive way than band immigrants in the lounge. However, their perceptions of non-loyal customers in the restaurant setting were not significantly different. 
Regarding the interaction effect for switching intention, loyal customers were more likely to switch when they perceived brand immigrants rather than brand tourists in the lounge. However, in the restaurant setting, the differences between loyal customers' perceptions of non-loyal customers were insignificant.

According to Figures 8 to 11 , regarding infringement, brand immigrants in the lounge were the only group to be rated higher than medium level (4.0) by loyal customers. However, for attitude, they were rated lower than medium level (4.0). Finally, regarding switching intention, only brand tourists in the lounge were rated lower than medium level (4.0) by loyal customers. With regards to infringement, loyal customers perceive the most infringement when loyal customers see brand immigrants in the lounge. Loyal customers have the most negative attitude toward non-loyal customers when they recognize brand immigrants in the lounge. Finally, loyal customers are more likely to have the intention to switch hotel when they see immigrants in both lounge and restaurant and tourists in the restaurant. Interestingly, loyal customers have less intention to switch when they see brand tourists in lounge. Therefore, it can be interpreted that loyal customers in luxury hotels are likely to have negative emotions regarding non-loyal customers of either type who enter this area thanks to promotions by an affiliated credit card companies.

Third, this study also examined the relationship among the four related perceptions of loyal customers including infringement, attitude, brand image, and switching intention. Since the data is collected on brand immigrants and brand tourists respectively using the experimental design method, two different structural models were proposed. The results revealed that when non-loyal customers were viewed as brand immigrants, all variables had significant relationships to all others. Specifically, 
according to the results, as expected, infringement had negative impacts on attitude and intention to switch hotel but had a positive impact on brand image, contrary to what is expected. It means that conflicts between loyal customers and non-loyal customers do not have much impact on hotel brand image. In other words, since this conflict stems from personal interaction, it does not have anything to do with brand image. After all, the results imply that when loyal customers perceive infringement by brand immigrants, they can change to different hotels with the same brand.

However, when loyal customers considered non-loyal customers to be brand tourists, no significant relationship was found between attitude and switching intention and between brand image and switching intention. It can be interpreted that when nonloyal customers are perceived as brand tourists, brand tourists' behaviors that cause loyal customers' feeling of infringement only influence the intention to switch hotel. Attitudes toward brand tourists and hotel brand image do not influence switching intention. According to multi group analysis, no relationships were found to be significantly different. Based on the results, it can be said that no matter which customers cause loyal customers' infringement, if they perceive infringement by others in the luxury hotel, they might try to change the hotel even though the hotel would not be a different brand of hotel.

Finally, according to the results of multigroup analysis, psychological ownership was not able to moderate the relationship among loyal customers' different perceptions when they view two types of non-loyal customers. This result differs from the results of the MANOVA test. In terms of the relationships among loyal customers' perceptions by non-loyal customers, psychological ownership did not have any significant effect. The result implies that loyal customers have an intention to switch hotel when they perceive 
physical infringement by other customers regardless of the areas divided by level of psychological ownership. In addition, for loyal customers, switching intention has to do with emotional perceptions.

\subsection{Implications}

This study could provide several theoretical contributions to the literature on the hospitality industry. First, the study illustrates the efficiency of its proposed framework in addressing some gaps in the literature and discussing the development of the proposed model. This study expanded research on the brand tourism effect by targeting customers in the luxury hotel market. In addition, unlike the original study (Bellezza \& Keinan, 2014) which focused on brand extension strategy, our latest study examined intergroup conflicts between customers (i.e., loyal customers and non-loyal customers) and the levels of psychological ownership in two different hotel settings. Therefore, this research will provide a stepping stone for future scholars who desire to expand their knowledge of customer attitudes, particularly in the luxury hotel market. It also provides new insights into the psychological mechanism, known as psychological ownership, by investigating perceptions about two types of non-loyal customers in different scenarios.

Second, this study was conducted using two different methodologies (i.e., MANOVA and PLS-SEM) with the same variables (i.e., infringement, attitude, brand image, and switching intention) in order to reveal loyal customers' different perceptions by two different non-loyal customers in two different areas (i.e., restaurant and lounge) distinguished by the level of psychological ownership. From the results, this study indicated results in diverse perspectives. In terms of the moderating effect examining group differences, as a result of MANOVA, each variable was shown to be different 
depending on the types of non-loyal customers and the types of background. On the other hand, as a consequence of PLS-SEM, in the relationship among the variables, the study did not find any significant differences between two groups. These results could provide a stronger theoretical and practical contribution.

The findings of this study could also provide insightful managerial implications for the hotel industry. First, the exclusive membership lounge in the luxury hotel is a valuable amenity that is provided to sustain long-term relationships with loyal customers. Therefore, maintaining these amenities is very important to perform more effective customer relationship marketing. According to the results, the outcome implies that loyal customers are likely to show negative emotions more clearly than positive emotions. Therefore, frontline employees should make more of an effort to prevent loyal customers' perceptions of a certain situation as being unfair. In this vein, the results suggest that loyal customers who are able to access exclusive amenities in luxury hotels are likely to respond negatively to brand immigrants.

Based on this result, the study can suggest that non-loyal customers' accessible benefits should be limited to prevent conflict between loyal customers and other customers. Specifically, it would be better if the benefits to non-loyal customers were provided at a place where loyal and non-loyal customers do not come face to face, such as in-room gifts or celebrations. If the hotel would like to provide some benefit to the non-loyal customers, it should not be at the expense of loyal customers. It would help hotel marketers to reduce loyal customers' negativity. Another possible suggestion is to provide benefits to returning customers rather than to first customers. In general, companies selling products or services tend to reward returning customers. Some airline companies, for example, allow customers to upgrade their seat according to their 
accumulated mileage. However, since only a limited number of seats is available for upgrade, companies provide the service only to a high level of loyal customers. Hotel marketers need to be aware of the perceptions of and impacts on loyal customers when non-loyal customers gain access to exclusive amenities. Then, they might decide that certain amenities can be given to non-loyal customers and others are reserved for loyal customers.

Second, this study examined the effect of psychological ownership of a background that can be divided into two different areas. Luxury hotel executives could alleviate the effects of brand immigration by strategically increasing the perceived separation between loyal customers and non-loyal customers. Specifically, they should provide loyal customers with at least one place which can only be accessed by loyal customers. The results of this study reveal that loyal customers' perception of infringement by non-loyal customers is the strongest predictor of their intention to switch hotel, out of the three predictors including infringement, attitude, and brand image. Therefore, in luxury hotels, at least one amenity that is reserved for loyal customers should be provided. Under this circumstance, the conflict between loyal customers and non-loyal customers could be significantly reduced. If the hotel still wishes to provide amenities to hotel members, a lower level of amenity could be made available to all guests.

Arising from this strategy, hotel executives could create a situation in which brand immigrants are more deserving of acceptance into the in-group community. In recent times, some hotels provide guest-only amenities, and they have limited public access spaces that do not include exclusive areas such as roof-top bars and pools. For example, Hotel Emma in San Antonio has a large volume of library which is only hotel 
guests can be accessed with a cardkey. The Roney, a historical hotel in Chicago, provides a new concept rooftop bar and there are specific times of day when only hotel guests can access this space. In this way, by creating a clear distinction between areas available to loyal and non-loyal customers, hotel marketers might attract more brand immigrants without causing negativity on the part of loyal customers.

Finally, in this study, consumers' switching intention is predicted through three variables: infringement, attitude and brand image. The result indicated that loyal customers' switching intention was influenced by their attitude toward brand immigrants and perceived brand image by brand immigrants as well as perceived infringement by brand immigrants. However, when non-loyal customers are viewed as brand tourists, infringement is the only factor that influences switching intention. It means that loyal customers do not like immigrants' behavior. Therefore, hotel marketers might consider how brand immigrants could be perceived more positively by loyal customers. In a recent study, Taylor and Strutton (2016) suggest that individuals are likely to upload and share their photos or videos on social media to indicate their high economic status. Regarding this behavior, in addition to the lounge, even in a restaurant, loyal customers have negative perceptions of non-loyal customers who use coupons for free meals from credit card points and who pretend to have in-group status.

To reduce loyal customers' negative reactions to non-loyal customers, marketers can set up a blog or an online community featuring hotel users' photos and videos. Psychologists such as Dholakia (2015) suggest that boasting or bragging is an inherent characteristic of individuals. Therefore, hotel operators might use these behaviors conducted by brand immigrants as advertising or content marketing. For example, in certain online communities, the community host creates a blog or sections to allow 
people to upload photos that they can show off their experiences. In this community, because most of community members visit this section to see their photos, they do not perceive negative attitudes or emotions. In this sense, it could be possible to create this kind of online community for the guests of luxury hotels targeting young customers. Then, it could change loyal customers' negative perspectives on non-loyal customers and negative emotions might be alleviated.

\subsection{Limitation and future studies}

In this study, some limitations were identified suggesting that a number of future studies should be conducted. The hypotheses proposed in this research were tested with potential guests of luxury hotels in a U.S. based population. Thus, the random sampling method used in this study might not represent the experiences of the U.S. population as a whole. In addition, according to many prior studies, interpersonal relationships in different cultures have an impact on consumers' purchasing behavior and normative influences (Kastanakis \& Balabanis, 2012; Urien \& Kilbourne, 2010). Therefore, to enable generalizability, future studies should involve broader cultures, with various sample groups collected from diverse countries in western culture and eastern culture. This study has not attempted to explain occurrences in a national population. Hence, future studies should continue to search for socio-demographic and psychographic differences, investigating the generalizability of this study's results.

In addition, in order to better predict behavioral intentions, the study can be extended by integrating other important possible variables into the proposed model. The proposed model contains conventional antecedents of brand loyalty and it spread the research framework among the constructs to determine how potential customers build 
stronger loyalty toward a certain hotel brand. To develop and examine brand loyalty in more detail, future scholars should explore various aspects of loyalty employing and broadening Oliver's (1997) four stage loyalty model, such as cognitive, affective, and conative loyalty components, and action loyalty (Han, Kim, \& Kim, 2011).

Lastly, future studies comparing and investigating additional group differences would be valuable both academically and practically. Future researchers could investigate socio-demographic aspects such as gender, income, ethnicity, and educational level as well as psychographic differences such as utilitarian and hedonist motivations, and individual differences to determine how they would affect travel experiences (e.g., travel frequency, purpose of travel, involvement with membership clubs). 


\section{APPENDIX A}

\section{IRB APPROVAL}

\section{In Institutional Review Board University of Missouri-Columbia}

190 Galena Hall Columbia, MO 65201

573-882-3181

irb@missouri.edu

March 08, 2018

Principal Investigator: Seunghwan Lee

Department: Hospitality Management

Your Exempt Application to project entitled The effect of non-core users on brand image and brand loyalty perceived by core users was reviewed and approved by the MU Institutional Review Board according to the terms and conditions described below:

$\begin{array}{ll}\text { IRB Project Number } & 2010849 \\ \text { IRB Review Number } & 235237\end{array}$

Initial Application Approval Date March 08, 2018

IRB Expiration Date March 08, 2019

Level of Review Exempt

Project Status Active - Open to

Exempt Categories $\quad 45$ CFR $46.101 \mathrm{~b}(2)$

Risk Level Minimal Risk

The principal investigator (PI) is responsible for all aspects and conduct of this study. The PI must comply with the following conditions of the approval:

1. No subjects may be involved in any study procedure prior to the IRB approval date or after the expiration date.

2. All unanticipated problems and deviations must be reported to the IRB within 5 business days.

3. All changes must be IRB approved prior to implementation unless they are intended to reduce immediate risk.

4. All recruitment materials and methods must be approved by the IRB prior to being used.

5. The Annual Exempt Form must be submitted to the IRB for review and approval at least 30 days prior to the project expiration date. If the study is complete, the Completion/Withdrawal Form may be submitted in lieu of the Annual Exempt Form

6. Maintain all research records for a period of seven years from the project completion date.

7. Utilize all approved research documents located within the attached files section of eCompliance. These documents are highlighted green.

If you are offering subject payments and would like more information about research participant payments, please click here to view the MU Business Policy and Procedure: http://bppm.missouri.edu/chapter2/2_250.html

If you have any questions, please contact the IRB at 573-882-3181 or irb@missouri.edu. 


\title{
APPENDIX B
}

\author{
CONSENT FORM
}

\section{The Effect of Psychological Ownership on Loyal Customers' Perceptions: Applying Brand Tourism Effect and Conspicuous Consumption to Luxury Hotel Marketing}

\author{
Consent Form for All Subjects
}

Hospitality Management

Survey Consent Form

You are invited to participate in a research study on hotel consumer behavior. You will complete this computer online survey with your responses (e.g. attitudes and behavioral intentions) within the context of the hospitality industry. Lastly, you will answer demographic questions. The entire survey will last no more than 15 minutes.

If you have questions regarding this study, please do not hesitate to contact Associate Professor Dae-Young Kim (Phone:573-884-7185; Office: 115 Eckles Hall; Email: kimdae@missouri.edu), Ph.D. Candidate Seunghwan Lee (Phone: 573-999-4533 or Email: slf2b@mail.missouri.edu) Hospitality Management of University of Missouri.

If you have read this form and decide to participate in this project, please understand that your participation is voluntary. You may choose not to participate at all, or you may refuse to participate in certain procedures or answer certain questions or discontinue your participation at any time without consequences.

The data that are collected from you will be held in strictest confidence. No personally identifiable information will be used to link back to you or to be shared with a third party. Your privacy will be protected to the maximum extent allowable by law. Your participation will help researchers to better understand sustainability strategies in the hospitality field so that we will be able to develop strategies for the next time you view them.

If you have questions or concerns about your role and rights as a research participant, or you would like to obtain information or offer input, or you would like to register a complaint about this study, you may contact, anonymously if you wish, the University of Missouri's Campus Institutional Review Board at 573-882-3181, or irb@missouri.edu or regular mail at 483 McReynolds, University of Missouri, Columbia, MO 65211. 


\section{APPENDIX C}

\section{SCENARIO 1}

\section{Hotel Description}

$\mathrm{ABC}$ hotel, a luxury segment of the M International, is one of the top high-end hotels. Similar to other hotels, this hotel brand provides access to a fancy executive club lounge to the limited number of loyalty membership customers and hotel guests who stay in a high-level room such as a suite. Recently, however, this hotel company has been providing access to the club lounge to other guests who are not staying in a high-level room nor are they loyalty members. This can be happening because the hotel has links to other businesses such as credit card companies or it promotes package deals that include access to the club lounge.

Imagine Emily, who is not a loyalty member of this hotel, but is visiting this hotel on vacation. During her stay, since her credit card company provides, as a benefit, access to the club lounge of the $\mathrm{ABC}$ hotel, she was able to enjoy herself at a member-exclusive club lounge. Since this hotel has offered access to the club lounge to more of the general guests, this limited-access area looked crowded.

(Scenario 1-1) Brand immigrant. Even though Emily cannot afford to use this lounge as an eligible hotel loyalty member, she thinks that she can be a part of the community of $\mathrm{ABC}$ members and consider herself a part of the $\mathrm{ABC}$ hotel customer group. In this situation, she thinks that her use of this lounge will allow her to show that she is a customer of this hotel brand. 
(Scenario 1-2) Brand tourist. Since Emily cannot afford to use this lounge as an eligible hotel loyalty member, she thinks that she does not belong to the high-level loyalty membership of the $\mathrm{ABC}$ hotel, but she wants to show her admiration for the $\mathrm{ABC}$ hotel. In this situation, her use of this lounge will allow her to show that she is an admirer of this hotel brand.

\section{Section 1.1 Emotion}

\begin{tabular}{l|lllllll}
\hline Emotion & $\begin{array}{l}\text { Extremely } \\
\text { unlikely (1) }\end{array}$ & Neutral (4) & $\begin{array}{r}\text { extremely } \\
\text { likely (7) }\end{array}$ \\
\hline $\begin{array}{l}\text { When you see Emily's situation, } \\
\text { how angry you would feel as a } \\
\text { loyalty member of this hotel? }\end{array}$ & (1) & (2) & (3) & (4) & (5) & (6) & (7) \\
\hline $\begin{array}{l}\text { When you see Emily's situation, } \\
\text { how proud you would feel as a } \\
\text { loyalty member of this hotel? }\end{array}$ & (1) & (2) & (3) & (4) & (5) & (6) & (7) \\
\hline $\begin{array}{l}\text { When you see Emily's situation, } \\
\text { how disappointed you would feel as } \\
\text { a loyalty member of this hotel? }\end{array}$ & (1) & (2) & (3) & (4) & (5) & (6) & (7) \\
\hline
\end{tabular}

\section{Section 1.2 Infringement}

\begin{tabular}{l|llllllll}
\hline Infringement & \multicolumn{3}{|l}{$\begin{array}{l}\text { Extremely } \\
\text { unlikely (1) }\end{array}$} & & Neutral (4) & \multicolumn{3}{r}{$\begin{array}{r}\text { Extremely } \\
\text { likely (7) }\end{array}$} \\
\hline $\begin{array}{l}\text { In this situation, Emily infringed on } \\
\text { my territory. }\end{array}$ & (1) & (2) & (3) & (4) & (5) & (6) & (7) \\
\hline $\begin{array}{l}\text { In this situation, Emily distracted } \\
\text { me during my visit at the lounge. }\end{array}$ & (1) & (2) & (3) & (4) & (5) & (6) & (7) \\
\hline $\begin{array}{l}\text { In this situation, Emily's actions } \\
\text { made me feel inhibited while } \\
\text { visiting the lounge. }\end{array}$ & (1) & (2) & (3) & (4) & (5) & (6) & (7) \\
\hline
\end{tabular}

\section{Section 1.3 Attitude}

Please indicate how you feel when you see the non-loyal customers

\begin{tabular}{|c|c|c|}
\hline \multicolumn{3}{|l|}{ Attitude } \\
\hline I dislike them & (6) & I like them \\
\hline $\begin{array}{l}\text { I react unfavorably to } \\
\text { their story }\end{array}$ & $\begin{array}{lllllll}\text { (1) } & \text { (2) } & \text { (3) } & \text { (4) } & \text { (5) } & \text { (6) } & \text { (7) }\end{array}$ & $\begin{array}{l}\text { I react favorably to } \\
\text { their story }\end{array}$ \\
\hline $\begin{array}{l}\text { I feel negative about } \\
\text { them }\end{array}$ & (1) (2) (3) (4) (5) & $\begin{array}{l}\text { I feel positive about } \\
\text { them }\end{array}$ \\
\hline
\end{tabular}




\begin{tabular}{|c|c|c|c|c|c|c|c|}
\hline \multirow{2}{*}{$\begin{array}{l}\text { Brand image } \\
\text { To what extent would access to the } \\
\text { club lounge make the image of this } \\
\text { hotel brand appear exclusive? }\end{array}$} & \multicolumn{3}{|c|}{$\begin{array}{l}\text { Extremely } \\
\text { unlikely (1) }\end{array}$} & \multicolumn{2}{|c|}{ Neutral (4) } & \multicolumn{2}{|c|}{$\begin{array}{r}\text { Extremely } \\
\text { likely (7) }\end{array}$} \\
\hline & (1) & (2) & (3) & (4) & (5) & (6) & (7) \\
\hline $\begin{array}{l}\text { To what extent would access to the } \\
\text { club lounge make the image of this } \\
\text { hotel brand appear high-status? }\end{array}$ & (1) & (2) & (3) & (4) & (5) & (6) & (7) \\
\hline $\begin{array}{l}\text { To what extent would access to the } \\
\text { club lounge make the image of this } \\
\text { hotel brand appear prestigious? }\end{array}$ & (1) & (2) & (3) & (4) & (5) & (6) & (7) \\
\hline
\end{tabular}

\section{Section 1.5 Switching intention}

\begin{tabular}{l|llllll}
\hline Switching intention & $\begin{array}{l}\text { Extremely } \\
\text { unlikely (1) }\end{array}$ & & Neutral (4) & $\begin{array}{r}\text { Extremely } \\
\text { likely (7) }\end{array}$ \\
\hline $\begin{array}{l}\text { When you see non-loyal customers } \\
\text { in this situation, how likely are you } \\
\text { to use a different hotel during your } \\
\text { next trip? }\end{array}$ & (1) & (2) & (3) & (4) & (5) & (6) \\
\hline $\begin{array}{l}\text { When you see non-loyal customers } \\
\text { in this situation, how likely are you } \\
\text { to return to this brand during your } \\
\text { next trip? }\end{array}$ & (1) & (2) & (3) & (4) & (5) & (6) \\
\hline $\begin{array}{l}\text { When you see non-loyal customers } \\
\text { in this situation, how likely are you } \\
\text { to stay in a different hotel during } \\
\text { your next trip? }\end{array}$ & (1) & (2) & (3) & (4) & (5) & (6)
\end{tabular}




\section{SCENARIO 2}

\section{Hotel Description}

The XYZ hotel is one of the top high-end hotels globally. Imagine Emily, who is traveling to New York City and goes to an Italian restaurant in the XYZ hotel to have lunch, because she has received a free, one-time meal coupon provided by her credit card company.

(Scenario 2-1) Brand immigrant. After she has lunch, she uploads her photos of her experience with the food in the restaurant on social media (e.g., Facebook or Instagram), with a hotel logo and a hashtag of \#XYZ. Even though Emily cannot afford to stay at the XYZ, she thinks that she can be a part of the community of XYZ members and considers herself a part of the XYZ brand. She also thinks that this lunch at the restaurant in the $\mathrm{XYZ}$ will allow her to show that she is a customer of this hotel brand.

(Scenario 2-2) Brand tourist. After she has lunch, she uploads her photos of her experience with the food in the restaurant on social media (e.g., Facebook or Instagram). Since Emily cannot afford to stay at the XYZ, she thinks that she does not belong to the high-level membership of the XYZ, but she still wants to show her admiration for the XYZ brand. This lunch at the restaurant in XYZ will allow her to show that she is a fan of this hotel brand.

\section{Section 2.1 Emotion}

\begin{tabular}{|c|c|c|c|c|}
\hline Emotion & $\begin{array}{l}\text { Extremely } \\
\text { unlikely (1) }\end{array}$ & & Neutral (4) & $\begin{array}{l}\text { Extremely } \\
\text { likely (7) }\end{array}$ \\
\hline $\begin{array}{l}\text { When you see Emily's situation, } \\
\text { how angry you would feel as a } \\
\text { loyalty member of this hotel? }\end{array}$ & (1) & (3) & (4) & (6) \\
\hline
\end{tabular}




\begin{tabular}{l|lllllll}
\hline $\begin{array}{l}\text { When you see Emily's situation, } \\
\text { how proud would you feel as a loyal } \\
\text { member of this hotel? }\end{array}$ & (1) & (2) & (3) & (4) & (5) & (6) & (7) \\
\hline $\begin{array}{l}\text { When you see Emily's situation, } \\
\text { how disappointed you would feel as } \\
\text { a loyal member of this hotel? }\end{array}$ & (1) & (2) & (3) & (4) & (5) & (6)
\end{tabular}

\section{Section 2.2 Infringement}

\begin{tabular}{l|lllllll}
\hline Infringement & $\begin{array}{l}\text { Disagree } \\
\text { (1) }\end{array}$ & & & Neutral (4) & $\begin{array}{r}\text { Agree } \\
\text { strongly (7) }\end{array}$ \\
\hline $\begin{array}{l}\text { In this situation, Emily infringed on } \\
\text { my territory. }\end{array}$ & (1) & (2) & (3) & (4) & (5) & (6) & (7) \\
\hline $\begin{array}{l}\text { In this situation, Emily distracted me } \\
\text { during my visit to the restaurant. }\end{array}$ & (1) & (2) & (3) & (4) & (5) & (6) & (7) \\
\hline $\begin{array}{l}\text { In this situation, Emily's actions } \\
\text { made me feel inhibited while visiting } \\
\text { the restaurant. }\end{array}$ & (1) & (2) & (3) & (4) & (5) & (6) & (7) \\
\hline
\end{tabular}

\section{Section 2.3 Attitude}

Please indicate how you feel when you see the non-loyal customers

\begin{tabular}{l|lllllll|l}
\hline \multicolumn{1}{l}{ Attitude } & (1) & (2) & (3) & (4) & (5) & (6) & (7) & I like them \\
\hline I dislike them & (1) & (2) & (3) & (4) & (5) & (6) & (7) & $\begin{array}{l}\text { I react favorably to } \\
\text { their story }\end{array}$ \\
\hline $\begin{array}{l}\text { I react unfavorably to } \\
\text { their story }\end{array}$ & (1) & (2) & (3) & (4) & (5) & (6) & (7) & $\begin{array}{l}\text { I feel positive about } \\
\text { them } \\
\text { I feel negative about }\end{array}$ \\
\hline
\end{tabular}

Section 2.4 Brand image

\begin{tabular}{|c|c|c|c|c|c|c|c|}
\hline \multirow{2}{*}{$\begin{array}{l}\text { Brand image } \\
\text { To what extent would visit to the } \\
\text { restaurant make the image of this } \\
\text { hotel brand appear exclusive? }\end{array}$} & \multicolumn{3}{|c|}{$\begin{array}{l}\text { Extremely } \\
\text { unlikely (1) }\end{array}$} & \multicolumn{2}{|c|}{ Neutral (4) } & \multicolumn{2}{|c|}{$\begin{array}{r}\text { Extremely } \\
\text { likely (7) }\end{array}$} \\
\hline & (1) & (2) & (3) & (4) & (5) & (6) & (7) \\
\hline $\begin{array}{l}\text { To what extent would visit to the } \\
\text { restaurant make the image of this } \\
\text { hotel brand appear high-status? }\end{array}$ & (1) & (2) & (3) & (4) & (5) & (6) & (7) \\
\hline $\begin{array}{l}\text { To what extent would visit to the } \\
\text { restaurant make the image of this } \\
\text { hotel brand appear prestigious? }\end{array}$ & (1) & (2) & (3) & (4) & (5) & (6) & (7) \\
\hline
\end{tabular}

Section 2.5 Switching intention

\begin{tabular}{|c|c|c|c|c|}
\hline Switching intention & $\begin{array}{l}\text { Extremely } \\
\text { unlikely (1) }\end{array}$ & & Neutral (4) & $\begin{array}{r}\text { Extremely } \\
\text { likely (7) }\end{array}$ \\
\hline $\begin{array}{l}\text { When you see non-loyal customers } \\
\text { in this situation, how likely are you } \\
\text { to use a different hotel during your } \\
\text { next trip? }\end{array}$ & (1) & (3) & (5) & (6) \\
\hline
\end{tabular}




\begin{tabular}{l|llllll}
\hline When you see non-loyal customers \\
in this situation, how likely are you \\
to return to this brand during your \\
next trip?
\end{tabular} (1)




\section{REFERENCES}

Aaker, D. A. (1991). Managing Brand Equity: Capitalizing on the Value of a Brand Name, New York.

Aaker, D. A. (1996). Measuring brand equity across products and markets. California management review, 38(3), 102-120.

Aaker, D. A. (2012). Building strong brands. New York, NY: Simon and Schuster.

Aberson, C. L. (2015). Positive intergroup contact, negative intergroup contact, and threat as predictors of cognitive and affective dimensions of prejudice. Group Processes \& Intergroup Relations, 18(6), 743-760.

Ajzen, I., \& Fishbein, M. (1980). Understanding attitudes and predicting social behavior. Englewood Cliffs, NJ: Prentice-Hall.

Ajzen, I. (1991). The theory of planned behavior. Organizational behavior and human decision processes, 50(2), 179-211.

Alhammad, F. (2012). Residents' attitudes towards tourism development in AL-Salt City, Jordan. Canadian Social Science, 8(1), 152-163.

Amaldoss, W., \& Jain, S. (2005). Pricing of conspicuous goods: A competitive analysis of social effects. The Journal of Marketing Research, 42(1), 30-42.

Androitis, A. (2018). The airport lounge, once a refuge, is a total zoo. Wall Street Journal. Retrieved from https://www.wsj.com/articles/the-airport-lounge-once-a-refuge-isa-total-zoo-1525106268.

Asatryan, V. S., \& Oh, H. (2008). Psychological ownership theory: An exploratory application in the restaurant industry. Journal of Hospitality \& Tourism Research, 32(3), 363-386.

Ashley, C., \& Noble, S. M. (2014). It's closing time: Territorial behaviors from customers in response to front line employees. Journal of Retailing, 90(1), 74-92.

Averill, J. R. (1983). Studies on anger and aggression: Implications for theories of emotion. American Psychologist, 38(11), 1145-1160.

Baer, M., \& Brown, G. (2012). Blind in one eye: How psychological ownership of ideas affects the types of suggestions people adopt. Organizational Behavior and Human Decision Processes, 118(1), 60-71.

Bagozzi, R. P., Gopinath, M., \& Nyer, P. U. (1999). The role of emotions in marketing. Journal of the academy of marketing science, 27(2), 184-206.

Bagozzi, R. P., \& Yi, Y. (1988). On the evaluation of structural equation models. Journal of the academy of marketing science, 16(1), 74-94. 
Bagwell, L. S., \& Bernheim, B. D. (1996). Veblen effects in a theory of conspicuous consumption. The American Economic Review, 86(3), 349-373.

Baloglu, S., \& Brinberg, D. (1997). Affective images of tourism destinations. Journal of Travel Research, 35(4), 11-15.

Bearden, W. O., \& Etzel, M. J. (1982). Reference group influence on product and brand purchase decisions. Journal of Consumer Research, 9(2), 183-194.

Belk, R. W. (1988). Possessions and the extended self. Journal of Consumer Research, 15(2), 139-168.

Bellezza, S., \& Keinan, A. (2014). Brand tourists: how non-core users enhance the brand image by eliciting pride. Journal of Consumer Research, 41(2), 397-417.

Berger, J., \& Heath, C. (2007). Where consumers diverge from others: Identity signaling and product domains. Journal of Consumer Research, 34(2), 121-134.

Berger, J., \& Heath, C. (2008). Who drives divergence? Identity signaling, outgroup dissimilarity, and the abandonment of cultural tastes. Journal of Personality and Social Psychology, 95(3), 593-607.

Berger, J., \& Ward, M. (2010). Subtle signals of inconspicuous consumption. Journal of Consumer Research, 37(4), 555-569.

Belk, R. W., Mayer, R., \& Bahn, K. (1982). The eye of the beholder: Individual differences in perceptions of consumption symbolism. In A. Mitchell (Ed.), Advances in Consumer Research, 9. (pp. 523-530)Ann Arbor, MI: Association for Consumer Research.

Berry, L. L. (1994). Relationship marketing of services - growing interest, emerging perspectives. Journal of the Academy of Marketing Science, 23(4), 236-245.

Bhattacharya, C. B., \& Sen, S. (2003). Consumer-company identification: A framework for understanding consumers' relationships with companies. Journal of Marketing, 67(2), 76-88.

Bian, Q., \& Forsythe, S. (2012). Purchase intention for luxury brands: A cross cultural comparison. Journal of Business Research, 65(10), 1443-1451.

Biel, A. L. (1992). How brand image drives brand equity. Journal of Advertising Research, 32(6), 6-12.

Billig, M. (1976). Social psychology and intergroup relations. London, Academic Press.

Bobo, L. (1988). Group conflict, prejudice, and the paradox of contemporary racial attitudes. In Eliminating racism (pp. 85-114). Boston, MA, Springer. 
Böhm, R., Rusch, H., \& Baron, J. (2018). The psychology of intergroup conflict: a review of theories and measures. Journal of Economic Behavior \& Organization. doi: 10.1016/j.jebo.2018.01.020

Bourdieu, P. (1984), Distinction: A Social Critique ofthe Judgment of Taste, Cambridge, MA: Harvard University Press.

Bowen, J. T., \& Chen, S. L. (2001). The relationship between customer loyalty and customer satisfaction. International Journal of Contemporary Hospitality Management, 13(5), 213-217.

Brewer, M. B. (1979). In-group bias in the minimal intergroup situation: A cognitivemotivational analysis. Psychological Bulletin, 86(2), 307-324.

Brown, G. (2009). Claiming a corner at work: Measuring employee territoriality in their workspaces. Journal of Environmental Psychology, 29(1), 44-52.

Brown, G., \& Robinson, S. L. (2011). Reactions to territorial infringement. Organization Science, 22(1), 210-224.

Brown, G., Lawrence, T. B., \& Robinson, S. L. (2005). Territoriality in organizations. Academy of Management Review, 30(3), 577-594.

Brown, G., Pierce, J. L., \& Crossley, C. (2014). Toward an understanding of the development of ownership feelings. Journal of Organizational Behavior, 35(3), $318-338$.

Brunner, T. A., Stöcklin, M., \& Opwis, K. (2008). Satisfaction, image and loyalty: new versus experienced customers. European Journal of Marketing, 42(9/10), 10951105 .

Castro, C. B., Armario, E. M., \& Ruiz, D. M. (2007). The influence of market heterogeneity on the relationship between a destination's image and tourists' future behaviour. Tourism Management, 28(1), 175-187.

Cavanaugh, L. A., Cutright, K. M., Luce, M. F., \& Bettman, J. R. (2011). Hope, pride, and processing during optimal and nonoptimal times of day. Emotion, 11(1), 38-46.

Chang, K. C., \& Tarn, D. D. (2008). Does service tangibilization work in the hotel industry? An experimental investigation. Asia Pacific Journal of Tourism Research, 13(4), 411-434.

Chaudhuri, A., \& Holbrook, M. B. (2001). The chain of effects from brand trust and brand affect to brand performance: the role of brand loyalty. Journal of Marketing, 65(2), $81-93$.

Childers, T. L., \& Rao, A. R. (1992). The influence of familial and peer-based reference groups on consumer decisions. Journal of Consumer Research, 19(2), 198-211. 
Chin, W. W. (2010). How to write up and report PLS analyses. In Handbook of partial least squares (pp. 655-690). Berlin, Heidelberg: Springer.

Choi, J. K., \& Bowles, S. (2007). The coevolution of parochial altruism and war. Science, 318(5850), 636-640.

Cohen, J. (1988). Statistical power analysis for the behavioral sciences (2nd ed.). Hillsdale, NJ: Lawrence Earlbaum Associates.

Cohen, J. B. \& Areni, C. S. (1991). Affect and consumer behavior. In T. S. Robertson \& H. H. Kassarjian (Eds.), Handbook of Consumer Behavior (pp. 188-240). Englewood Cliffs, N.J: Prentice-Hall.

Correia, A., \& Moital, M. (2009). Antecedents and consequences of prestige motivation in tourism: An expectancy-value motivation. In Handbook of Tourist Behavior (pp. 34-50). New York, NY: Routledge.

Correia, A., \& Kozak, M. (2012). Exploring prestige and status on domestic destinations: The case of Algarve. Annals of Tourism Research, 39(4), 1951-1967.

Cretu, A. E., \& Brodie, R. J. (2007). The influence of brand image and company reputation where manufacturers market to small firms: A customer value perspective. Industrial Marketing Management, 36(2), 230-240.

Cristini, H., Kauppinen-Räisänen, H., Barthod-Prothade, M., \& Woodside, A. (2017). Toward a general theory of luxury: Advancing from workbench definitions and theoretical transformations. Journal of Business Research, 70, 101-107.

Danziger, P. (2011, May 12). Sound strategy or dumb advice? Luxury Society. Retrieved from http://luxurysociety.com/articles/2010/11/sound-strategy-or-dumb-advice

Dawes, J. (2008). Do data characteristics change according to the number of scale points used? An experiment using 5-point, 7-point and 10-point scales. International Journal of Market Research, 50(1), 61-104.

Deci, E. L., \& Ryan, R. M. (1985). Cognitive evaluation theory. In Intrinsic motivation and self-determination in human behavior (pp. 43-85). Boston, MA: Springer.

Decrop, A., \& Derbaix, C. (2010). Pride in contemporary sport consumption: a marketing perspective. Journal of the Academy of Marketing Science, 38(5), 586-603.

Dholakia (2015). How to brag effectively on social media. Psychology Today. Retrieved from https://www.psychologytoday.com/us/blog/the-science-behindbehavior/201809/how-brag-effectively-social-media

Casado Diaz, A. B., \& Más Ruíz, F. J. (2002). The consumer's reaction to delays in service. International Journal of Service Industry Management, 13(2), 118-140. 
Dijksterhuis, A., \& Bargh, J. A. (2001). The perception-behavior expressway: Automatic effects of social perception on social behavior. In Advances in Experimental Social Psychology (Vol. 33, pp. 1-40). London: Academic Press.

Eagly, A. H., \& Chaiken, S. (1993). The psychology of attitudes. Forth Worth, TX: Harcourt Brace.

Escalas, J. E., \& Bettman, J. R. (2003). You are what they eat: The influence of reference groups on consumers' connections to brands. Journal of Consumer Psychology, 13(3), 339-348.

Faircloth, J. B., Capella, L. M., \& Alford, B. L. (2001). The effect of brand attitude and brand image on brand equity. The Journal of Marketing Theory and Practice, 9(3), $61-75$.

Fazio, R. H. (1989). On the power and functionality of attitudes: The role of attitude accessibility. In A. R. Pratkanis, S. J. Breckler, \& A. G. Greenwald (Eds.), Attitude structure andfunction (pp. 153-179). Hillsdale, NJ: Erlbaum.

Fischer, A. H., \& Roseman, I. J. (2007). Beat them or ban them: the characteristics and social functions of anger and contempt. Journal of Personality and Social Psychology, 93(1), 103-115.

Fishbein, M., \& Ajzen, I. (1975). Belief, attitude, intention and behavior: An introduction to theory and research. Reading, MA: Addison- Wesley

Fournier, S. (1998). Consumers and their brands: Developing relationship theory in consumer research. Journal of Consumer Research, 24(4), 343-373.

Fournier, S. and Lee, L. (2009). Getting brand communities right. Harvard Business Review, 87(4).

Fornell, C., \& Larcker, D. F. (1981). Evaluating structural equation models with unobservable variables and measurement error. Journal of marketing research, 18, 39-50.

Franke, N., Schreier, M., \& Kaiser, U. (2010). The "I designed it myself" effect in mass customization. Management Science, 56(1), 125-140.

Frijda, N. H., Kuipers, P., \& Ter Schure, E. (1989). Relations among emotion, appraisal, and emotional action readiness. Journal of personality and social psychology, 57(2), 212-228.

Fuchs, C., Prandelli, E., Schreier, M., \& Dahl, D. W. (2013). All that is users might not be gold: How labeling products as user designed backfires in the context of luxury fashion brands. Journal of Marketing, 77(5), 75-91

Funches, V. (2016). A model of consumer anger. Journal of Marketing Management, 4(1), $31-42$. 
Furby, L. (1978). Possession in humans: An exploratory study of its meaning and motivation. Social Behavior and Personality: an International Journal, 6(1), 4965.

Gardner, B. B., \& Levy, S. J. (1955). The product and the brand. Harvard Business Review, 33 (March-April).

Gefen, D., Straub, D., \& Boudreau, M. C. (2000). Structural equation modeling and regression: Guidelines for research practice. Communications of the Association for Information Systems, 4(7), 2-77.

Goldsmith, R. E., Flynn, L. R., \& Eastman, J. K. (1996). Status consumption and fashion behavior: An exploratory study. Association of Marketing Theory and Practice Proceedings 309-316.

Griffiths, M. A., \& Gilly, M. C. (2012). Dibs! Customer territorial behaviors. Journal of Service Research, 15(2), 131-149.

Gwinner, K. P., Gremler, D. D., \& Bitner, M. J. (1998). Relational benefits in services industries: the customer's perspective. Journal of the Academy of Marketing Science, 26(2), 101-114.

Hair, J., Black, W., Babin, B., Anderson, R., \& Tatham, R. (2006). Multivariate data analysis (6th ed.). Uppersaddle River, N.J.: Pearson Prentice Hall.

Hair Jr, J. F., Hult, G. T. M., Ringle, C., \& Sarstedt, M. (2016). A primer on partial least squares structural equation modeling (PLS-SEM). Thousand Oaks: Sage.

Han, H., Hsu, L. T. J., \& Sheu, C. (2010). Application of the theory of planned behavior to green hotel choice: Testing the effect of environmental friendly activities. Tourism Management, 31(3), 325-334.

Han, H., Kim, Y., \& Kim, E. K. (2011). Cognitive, affective, conative, and action loyalty: Testing the impact of inertia. International Journal of Hospitality Management, 30(4), 1008-1019.

Han, Y. J., Nunes, J. C., \& Drèze, X. (2010). Signaling status with luxury goods: The role of brand prominence. Journal of Marketing, 74(4), 15-30.

Hansen, T., Jensen, J. M., \& Solgaard, H. S. (2004). Predicting online grocery buying intention: a comparison of the theory of reasoned action and the theory of planned behavior. International Journal of Information Management, 24(6), 539-550.

Harmon-Jones, E., Sigelman, J., Bohlig, A., \& Harmon-Jones, C. (2003). Anger, coping, and frontal cortical activity: The effect of coping potential on anger-induced left frontal activity. Cognition \& Emotion, 17(1), 1-24.

Hart, A. E., \& Rosenberger III, P. J. (2004). The effect of corporate image in the formation of customer loyalty: An Australian replication. Australasian Marketing Journal $(A M J), 12(3), 88-96$. 
Harwood, T., \& Garry, T. (2010). 'It's Mine!'-Participation and ownership within virtual co-creation environments. Journal of Marketing Management, 26(3-4), 290-301.

Haslam, S. A., \& Platow, M. J. (2001). Your wish is our command: The role of shared social identity in translating a leader's vision into followers' action. In: M. A. Hogg $\&$ D. J. Terry (Eds), Social Identity Processes in Organizational Contexts (pp. 213228). Philadelphia, PA: Psychology Press.

Haywood, K. M. (1988). Repeat patronage: cultivating alliances with customers. International Journal of Hospitality Management, 7(3), 225-237.

Helgeson, J. G., \& Supphellen, M. (2004). A conceptual and measurement comparison of self-congruity and brand personality: The impact of socially desirable responding. International Journal of Market Research, 46(2), 205-233.

Hillenbrand, C., \& Money, K. (2007). Corporate responsibility and corporate reputation: Two separate concepts or two sides of the same coin? Corporate Reputation Review, 10(4), 261-277.

Hillenbrand, C., \& Money, K. G. (2015). Unpacking the mechanism by which psychological ownership manifests at the level of the individual: A dynamic model of identity and self. Journal of Marketing Theory and Practice, 23(2), 148-165.

Hoffmann, A. O., \& Birnbrich, C. (2012). The impact of fraud prevention on bankcustomer relationships: An empirical investigation in retail banking. International journal of bank marketing, 30(5), 390-407.

Höger, E., (2018). Growth and change: The shifting luxury travel market. Hospitalitynet. Retrieved from https://www.hospitalitynet.org/news/4086716.html

Huh, C., \& Vogt, C. A. (2008). Changes in residents' attitudes toward tourism over time: A cohort analytical approach. Journal of Travel Research, 46(4), 446-455.

Hyun, S. S., \& Kim, I. (2014). Identifying optimal rapport-building behaviors in inducing patrons' emotional attachment in luxury restaurants. Journal of Hospitality \& Tourism Research, 38(2), 162-198.

James, W. (1950). The principles of psychology (Vol. I). New York: Dover. (Original work published 1890).

Jang, Y. J., Cho, S. B., \& Kim, W. G. (2013). Effect of restaurant patrons' regret and disappointment on dissatisfaction and behavioral intention. Journal of Travel \& Tourism Marketing, 30(5), 431-444.

Jarvenpaa, S. L., \& Todd, P. A. (1997). Is there a future for retailing on the Internet? Electronic Marketing and the Consumer, 1(12), 139-154.

Jiang, W., Dev, C. S., \& Rao, V. R. (2002). Brand extension and customer loyalty: Evidence from the lodging industry. Cornell Hotel and Restaurant Administration Quarterly, 43(4), 5-16. 
Choo, H., Moon, H., Kim, H., \& Yoon, N. (2012). Luxury customer value. Journal of Fashion Marketing and Management: An International Journal, 16(1), 81-101.

Jussila, I., \& Tuominen, P. (2010). Exploring the consumer co-operative relationship with their members: an individual psychological perspective on ownership. International Journal of Co-operative Management, 5(1), 23-33.

Jussila, I., Tarkiainen, A., Sarstedt, M., \& Hair, J. F. (2015). Individual psychological ownership: concepts, evidence, and implications for research in marketing. Journal of Marketing Theory and Practice, 23(2), 121-139.

Kapferer, J. N., \& Laurent, G. (2016). Where do consumers think luxury begins? A study of perceived minimum price for 21 luxury goods in 7 countries. Journal of Business Research, 69(1), 332-340.

Kastanakis, M. N., \& Balabanis, G. (2012). Between the mass and the class: Antecedents of the "bandwagon" luxury consumption behavior. Journal of Business Research, 65(10), 1399-1407.

Kastanakis, M. N., \& Balabanis, G. (2014). Explaining variation in conspicuous luxury consumption: An individual differences' perspective. Journal of Business Research, 67(10), 2147-2154.

Keller, K. L. (1993). Conceptualizing, measuring, and managing customer-based brand equity. Journal of Marketing, 57(1), 1-22.

Keller, K. L. (2001). Building customer-based brand equity: A blueprint for creating strong brands (pp. 3-27). Cambridge, MA: Marketing Science Institute.

Kirk, C. P., Peck, J., \& Swain, S. D. (2018). Property lines in the mind: Consumers' psychological ownership and their territorial responses. Journal of Consumer Research, 45(1), 148-168.

Kirmani, A., Sood, S., \& Bridges, S. (1999). The ownership effect in consumer responses to brand line stretches. Journal of Marketing, 63(1), 88-101.

Kline, R. (2005). Principles and practices of structural equation modeling ( $2 \mathrm{n}$ ed.). New York, NY: Guilford

Kline, R. (2011). Convergence of structural equation modeling and multilevel modeling. London: Sage, 562-589.

Kock, N., \& Lynn, G. (2012). Lateral collinearity and misleading results in variance-based SEM: An illustration and recommendations. Journal of the Association for information System, 13, 546-580.

Kosterman, R., \& Feshbach, S. (1989). Toward a measure of patriotic and nationalistic attitudes. Political Psychology, 10(2), 257-274. 
Kotler, P., Bowen, J. T., Makens, J. C., \& Baloglu, S. (2013). Marketing for hospitality and tourism. $4^{\text {th }}$ Edition. Uppersaddle River, N.J: Prentice Hall,

Lee, S., Baumgartner, H., \& Winterich, K. P. (2018). Did they earn it? Observing unearned luxury consumption decreases brand attitude when observers value fairness. Journal of Consumer Psychology 28(3), 412-436.

Lee, J. S., Tsang, N., \& Pan, S. (2015). Examining the differential effects of social and economic rewards in a hotel loyalty program. International Journal of Hospitality Management, 49, 17-27.

Lee, S., \& Kim, D. Y. (2018). Brand personality of Airbnb: Application of user involvement and gender differences. Journal of Travel \& Tourism Marketing, 35(1), 32-45.

Leibenstein, H. (1950). Bandwagon, snob, and Veblen effects in the theory of consumers' demand. The Quarterly Journal of Economics, 64(2), 183-207.

LeVine, R. A., \& Campbell, D. T. (1972). Ethnocentrism: Theories of conflict, ethnic attitudes, and group behavior. Oxford, England: John Wiley \& Sons.

Lothian, A. (2009). Living in a den of thieves: Fan video and digital challenges to ownership. Cinema Journal, 48(4), 130-136.

Loureiro, S. M. C., \& de Araújo, C. M. B. (2014). Luxury values and experience as drivers for consumers to recommend and pay more. Journal of Retailing and Consumer Services, 21(3), 394-400.

Low, G. S., \& Lamb Jr, C. W. (2000). The measurement and dimensionality of brand associations. Journal of Product \& Brand Management, 9(6), 350-370.

Martin, G. (2015). Getting into the airport lounge is about to get more difficult. Skift. Retrieved from https://skift.com/2015/08/17/getting-into-the-airport-lounge-isabout-to-get-more-difficult/

Martin, G. S., \& Brown, T. J. (1990). In search of brand equity: the conceptualization and measurement of the brand impression construct.Marketing Theory and Applications, 2(1), 431-438.

Mascolo, M. F., \& Fischer, K. W. (1995). Developmental transformations in appraisals for pride, shame, and guilt.

Mattila, A. S. (2006). How affective commitment boosts guest loyalty (and promotes frequent-guest programs). Cornell Hotel and Restaurant Administration Quarterly, 47(2), 174-181.

McAlexander, J. H., Kim, S. K., \& Roberts, S. D. (2003). Loyalty: The influences of satisfaction and brand community integration. Journal of Marketing Theory and Practice, 11(4), 1-11. 
McLaren, L., \& Johnson, M. (2007). Resources, group conflict and symbols: explaining anti-immigration hostility in Britain. Political Studies, 55(4), 709-732.

Mitchell, A. A., \& Olson, J. C. (1981). Are product attribute beliefs the only mediator of advertising effects on brand attitude? Journal of Marketing Research, 18(3) 318332.

Moreau, C. P., Bonney, L., \& Herd, K. B. (2011). It's the thought (and the effort) that counts: How customizing for others differs from customizing for oneself. Journal of Marketing, 75(5), 120-133.

Mukhopadhyay, A., \& Johar, G. V. (2009). Indulgence as self-reward for prior shopping restraint: A justification-based mechanism. Journal of Consumer Psychology, 19(3), 334-345.

Muniz, A. M., \& O'Guinn, T. C. (2001). Brand community. Journal of Consumer Research, 27(4), 412-432.

Norton, M. I., Mochon, D., \& Ariely, D. (2012). The IKEA effect: When labor leads to love. Journal of Consumer Psychology, 22(3), 453-460.

Nunnally, J. (1978). Psychometric methods. New Yrok, NY: McGraw-Hill.

O'Cass, A., \& McEwen, H. (2004). Exploring consumer status and conspicuous consumption. Journal of Consumer Behaviour: An International Research Review, 4(1), 25-39.

O’Keefe, D. J. (2002). Persuasion: Theory and research (Vol. 2). Sage.

Oliver, R. L. (1997). Loyalty and profit: Long-term effects of satisfaction: A Behavioral perspective on the consumer, New York, NY: McGraw-Hill.

Oliver, R. L. (1999). Whence consumer loyalty? Journal of Marketing, 63, 33-44.

Paolacci, G., Chandler, J., \& Ipeirotis, P. G. (2010). Running experiments on Amazon Mechanical Turk. Judgment and Decision Making, 5, 411-419. Retrieved from http://journal.sjdm.org/10/10630a/ jdm10630a.pdf

Park, C. W., Milberg, S., \& Lawson, R. (1991). Evaluation of brand extensions: The role of product feature similarity and brand concept consistency. Journal of consumer research, 18(2), 185-193.

Peck, J., \& Shu, S. B. (2009). The effect of mere touch on perceived ownership. Journal of Consumer Research, 36(3), 434-447.

Peck, J., Barger, V. A., \& Webb, A. (2013). In search of a surrogate for touch: The effect of haptic imagery on perceived ownership. Journal of Consumer Psychology, 23(2), 189-196. 
Peterson, R. A. (1995). Relationship marketing and the consumer. Journal of the Academy of Marketing Science, 23(4), 278-281.

Petrick, J. F. (2004). The roles of quality, value, and satisfaction in predicting cruise passengers' behavioral intentions. Journal of Travel Research, 42(4), 397-407.

Pierce, J. L., Kostova, T., \& Dirks, K. T. (2001). Toward a theory of psychological ownership in organizations. Academy of Management Review, 26(2), 298-310.

Pierce, J. L., Kostova, T., \& Dirks, K. T. (2003). The state of psychological ownership: Integrating and extending a century of research. Review of General psychology, 7(1), 84 .

Piron, F. (2000). Consumers' perceptions of the country-of-origin effect on purchasing intentions of (in) conspicuous products. Journal of Consumer Marketing, 17(4), 308-321.

Rohmann, A., Florack, A., \& Piontkowski, U. (2006). The role of discordant acculturation attitudes in perceived threat: An analysis of host and immigrant attitudes in Germany. International Journal of Intercultural Relations, 30(6), 683-702.

Romani, S., Grappi, S., \& Bagozzi, R. P. (2013). My anger is your gain, my contempt your loss: Explaining consumer responses to corporate wrongdoing. Psychology \& Marketing, 30(12), 1029-1042.

Roper, S., Caruana, R., Medway, D., \& Murphy, P. (2013). Constructing luxury brands: exploring the role of consumer discourse. European Journal of Marketing, 47(3/4), $375-400$.

Roux, E., Tafani, E., \& Vigneron, F. (2017). Values associated with luxury brand consumption and the role of gender. Journal of Business Research, 71, 102-113.

Ruback, R. B., Pape, K. D., \& Doriot, P. (1989). Waiting for a phone: Intrusion on callers leads to territorial defense. Social Psychology Quarterly, 52(3), 232-241.

Rucker, D. D., \& Galinsky, A. D. (2008). Desire to acquire: Powerlessness and compensatory consumption. Journal of Consumer Research, 35(2), 257-267.

Rucker, D. D., Galinsky, A. D., \& Dubois, D. (2012). Power and consumer behavior: How power shapes who and what consumers value. Journal of Consumer Psychology, 22(3), 352-368.

Rudmin, F. W., \& Berry, J. W. (1987). Semantics of ownership: A free-recall study of property. The Psychological Record, 37(2), 257-268.

Ryu, K., Han, H., \& Kim, T. H. (2008). The relationships among overall quick-casual restaurant image, perceived value, customer satisfaction, and behavioral intentions. International Journal of Hospitality Management, 27(3), 459-469. 
Ryu, K., \& Jang, S. (2006). Intention to experience local cuisine in a travel destination: The modified theory of reasoned action. Journal of Hospitality \& Tourism Research, 30(4), 507-516.

Sharpley, R. (2014). Host perceptions of tourism: A review of the research. Tourism Management, 42, 37-49.

Sherif, M. (2015). Group conflict and cooperation: Their social psychology. New York, NY: Psychology Press.

Sherif, M., \& Sherif, C. W. (1953). Groups in harmony and tension: An integration of studies of intergroup relations. Oxford, UK: Harper.

Sherif, M., \& Sherif, C. W. (1969). Ingroup and intergroup relations: Experimental analysis. In Sherif, M., \& Sherif, C. W.(Eds.), Social Psychology, (pp. 221-266). New York, NY: Harper\&Row.

Sheth, J. N., \& Parvatiyar, A. (2000). Relationship marketing in consumer markets. Handbook of Relationship Marketing (pp. 171-208). London: Sage Publications.

Shimp, C. P. (2001). Behavior as a social construction. Behavioural Processes, 54(1-3), $11-32$.

Shoemaker, S., \& Lewis, R. C. (1999). Customer loyalty: the future of hospitality marketing. International Journal of Hospitality Management, 18(4), 345-370.

Shu, S. B., \& Peck, J. (2011). Psychological ownership and affective reaction: Emotional attachment process variables and the endowment effect. Journal of Consumer Psychology, 21(4), 439-452.

Sidanius, J., \& Pratto, F. (2001). Social dominance: An intergroup theory of social hierarchy and oppression. Cambridge: Cambridge University Press.

Sirgy, M. J., \& Su, C. (2000). Destination image, self-congruity, and travel behavior: Toward an integrative model. Journal of Travel Research, 38(4), 340-352.

Smith Travel Research. (2017). Forecast - US and Chain scales. Retrieved from https://www.str.com/Media/Default/Samples/NA_USChainScaleForecast_Sample .pdf

Söderlund, M., \& Colliander, J. (2015). Loyalty program rewards and their impact on perceived justice, customer satisfaction, and repatronize intentions. Journal of Retailing and Consumer Services, 25, 47-57.

Spears, N., \& Yazdanparast, A. (2014). Revealing obstacles to the consumer imagination. Journal of Consumer Psychology, 24(3), 363-372.

Spears, N., \& Yazdanparast, A. (2014). Revealing obstacles to the consumer imagination. Journal of Consumer Psychology, 24(3), 363-372. 
Stephan, W. G., \& Stephan, C. W. (1985). Intergroup anxiety. Journal of social issues, 41(3), 157-175.

Stephan, W.G., \& Stephan, C.W. (1996). Intergroup Relations. Boulder, CO: Westview Press

Stephan, C. W., \& Stephan, W. S. (2013). An integrated threat theory of prejudice. In Reducing Prejudice and Discrimination (pp. 33-56). New York, NY: Psychology Press.

Stephan, W. G., Diaz-Loving, R., \& Duran, A. (2000). Integrated threat theory and intercultural attitudes: Mexico and the United States. Journal of Cross-Cultural Psychology, 31(2), 240-249.

Stephan, W. G., Ybarra, O., \& Bachman, G. (1999). Prejudice toward immigrants 1. Journal of Applied Social Psychology, 29(11), 2221-2237.

Stephan, W. G., Ybarra, O., Martinez, C. M., Schwarzwald, J., \& Tur-Kaspa, M. (1998). Prejudice toward immigrants to Spain and Israel: An integrated threat theory analysis. Journal of Cross-Cultural Psychology, 29(4), 559-576.

Stokburger-Sauer, N. E., \& Teichmann, K. (2013). Is luxury just a female thing? The role of gender in luxury brand consumption. Journal of Business Research, 66(7), 889896.

Tajfel, H., \& Turner, J. (2001). An integrative theory of intergroup conflict. In M. A. Hogg $\&$ D. Abrams (Eds.), Key readings in social psychology. Intergroup relations: Essential readings (pp. 94-109). New York, NY: Psychology Press.

Tajfel, H., \& Turner, J. C. (2004). The social identity theory of intergroup behavior. In J. T. Jost \& J. Sidanius (Eds.), Key readings in social psychology. Political psychology: Key readings (pp. 276-293). New York, NY: Psychology Press.

Taylor, D. G., \& Strutton, D. (2016). Does Facebook usage lead to conspicuous consumption? The role of envy, narcissism and self-promotion. Journal of Research in Interactive Marketing, 10(3), 231-248.

Teo, T. S. (2001). Demographic and motivation variables associated with Internet usage activities. Internet Research, 11(2), 125-137.

Thompson, C. J., Rindfleisch, A., \& Arsel, Z. (2006). Emotional branding and the strategic value of the doppelgänger brand image. Journal of Marketing, 70(1), 50-64.

Ting, D. (2016). The biggest challenges and opportunities for luxury hotels in 2017, explained. Skift. Retrieved from https://skift.com/2016/12/22/the-biggestchallenges-and-opportunities-for-luxury-hotels-in-2017-explained/

Todd, S. (2001). Self-concept: A tourism application. Journal of Consumer Behaviour, 1(2), 184-196. 
Tovar, C., \& Lockwood, M. (2008). Social impacts of tourism: An Australian regional case study. International Journal of Tourism Research, 10(4), 365-378.

Tracy, J. L., \& Robins, R. W. (2004). Show your pride: Evidence for a discrete emotion expression. Psychological Science, 15(3), 194-197.

Trigg, A. B. (2001). Veblen, Bourdieu, and conspicuous consumption. Journal of Economic Issues, 35(1), 99-115.

Truong, Y., McColl, R., \& Kitchen, P. J. (2009). New luxury brand positioning and the emergence of masstige brands. Journal of Brand Management, 16(5-6), 375-382.

Turner, J. C., Hogg, M. A., Oakes, P. J., Reicher, S. D., \& Wetherell, M. S. (1987). Rediscovering the social group: A self-categorization theory. Oxford: Basil Blackwell.

Tynan, C., McKechnie, S., \& Chhuon, C. (2010). Co-creating value for luxury brands. Journal of Business Research, 63(11), 1156-1163.

Unity Marketing. (2012). Luxury Tracking Study. Retrieved from http://www.unitymarketingonline.com/catalog/product_detail.php/pid=73 subid=112/index.html

Upadhayay, S. (2015). Luxury hotel market by type (business hotels, airport hotels, suite hotels, resorts) - Global opportunity analysis and industry forecast, 2014 - 2022. Allied Market Research. Retrieved from https://www.alliedmarketresearch.com/press-release/luxury-hotel-market.html.

Urien, B., \& Kilbourne, W. (2011). Generativity and self-enhancement values in ecofriendly behavioral intentions and environmentally responsible consumption behavior. Psychology \& Marketing, 28(1), 69-90.

Van Dijk, W. W., van der Pligt, J., Zeelenberg, M., \& Fischer, A. H. (1998). Different or the same? Outcome-related and person-related disappointment. In Proceedings of the 10th Conference of the International Society for Research on Emotions (pp. 162-165).

Veblen, T. (1899). 1994 The theory of the leisure class. New Brunswick, NJ: Transaction Publishers.

Vigneron, F., \& Johnson, L. W. (1999). A review and a conceptual framework of prestigeseeking consumer behavior. Academy of Marketing Science Review, 1(1), 1-15.

Walls, A., Okumus, F., Wang, Y., \& Kwun, D. J. W. (2011). Understanding the consumer experience: An exploratory study of luxury hotels. Journal of Hospitality Marketing \& Management, 20(2), 166-197.

Ward, M. K., \& Dahl, D. W. (2014). Should the devil sell Prada? Retail rejection increases aspiring consumers' desire for the brand. Journal of Consumer Research, 41(3), 590-609. 
White, K., \& Dahl, D. W. (2006). To be or not be? The influence of dissociative reference groups on consumer preferences. Journal of Consumer Psychology, 16(4), 404414.

White, K., \& Dahl, D. W. (2007). Are all out-groups created equal? Consumer identity and dissociative influence. Journal of Consumer Research, 34(4), 525-536.

Wiedmann, K. P., Hennigs, N., \& Siebels, A. (2009). Value-based segmentation of luxury consumption behavior. Psychology \& Marketing, 26(7), 625-651.

Wong, A., \& Zhou, L. (2005). Consumers' motivations for consumption of foreign products: an empirical test in the People's Republic of China. Retrieved from http://www.u21 global.edu.sg/PartnerAdmin/ViewContent? module1/4DOCUMENTLIBRARY\&oid1/414097

Yamagishi, T., Jin, N., \& Kiyonari, T. (1999). Bounded generalized reciprocity: Ingroup boasting and ingroup favoritism. Advances in Group Processes, 16(1), 161-197.

Yang, F. X., \& Lau, V. M. (2015). "LuXurY" hotel loyalty-a comparison of Chinese Gen $\mathrm{X}$ and $\mathrm{Y}$ tourists to Macau. International Journal of Contemporary Hospitality Management, 27(7), 1685-1706.

Yang, W., Mattila, A. S., \& Hou, Y. (2013). The effect of regulatory focus and delay type on consumers' reactions to delay. International Journal of Hospitality Management, 32, 113-120.

Zeelenberg, M., \& Pieters, R. (2004). Beyond valence in customer dissatisfaction: A review and new findings on behavioral responses to regret and disappointment in failed services. Journal of Business Research, 57(4), 445-455.

Zeelenberg, M., van Dijk, W. W., Manstead, A. S., \& van der Pligt, J. (2000). On bad decisions and disconfirmed expectancies: The psychology of regret and disappointment. Cognition \& Emotion, 14(4), 521-541.

Zeelenberg, M., van Dijk, W. W., SR Manstead, A., \& van der Pligt, J. (1998). The experience of regret and disappointment. Cognition \& Emotion, 12(2), 221-230.

Zeithaml, V. A. (1988). Consumer perceptions of price, quality, and value: a means-end model and synthesis of evidence. Journal of Marketing, 52(3), 2-22.

Zeelenberg, M., van Dijk, W. W., Van der Pligt, J., Manstead, A. S., Van Empelen, P., \& Reinderman, D. (1998). Emotional reactions to the outcomes of decisions: The role of counterfactual thought in the experience of regret and disappointment. Organizational behavior and human decision processes, 75(2), 117-141. 


\section{VITA}

Seung Hwan Lee was born in February 1984, in Seoul, South Korea. In the spring of 2007, he completed his bachelors degree from Pai Chai University and received a masters degree in hotel and tourism management at Kyung Hee University in August 2011. In the fall of 2013, he joined the department of hospitality management at the University of Missouri to pursue a doctoral degree (Ph.D.). During his graduate studies, he focused on the research area of consumer behaviors, brand management, and information technology in the hospitality industry. During his academic years, he published five peer reviewed journal articles and presented eleven papers at international conferences. He received his doctoral degree (Ph.D.) in December 2018. 